Portland State University

PDXScholar

$1-1-2012$

\title{
Mining Culture in Roman Dacia: Empire, Community, and Identity at the Gold Mines of Alburnus Maior ca.107-270 C.E.
}

Heather Ann Pundt

Portland State University

Follow this and additional works at: https://pdxscholar.library.pdx.edu/open_access_etds Let us know how access to this document benefits you.

\section{Recommended Citation}

Pundt, Heather Ann, "Mining Culture in Roman Dacia: Empire, Community, and Identity at the Gold Mines of Alburnus Maior ca.107-270 C.E." (2012). Dissertations and Theses. Paper 800.

https://doi.org/10.15760/etd.800

This Thesis is brought to you for free and open access. It has been accepted for inclusion in Dissertations and Theses by an authorized administrator of PDXScholar. Please contact us if we can make this document more accessible: pdxscholar@pdx.edu. 
Mining Culture in Roman Dacia: Empire, Community, and Identity at the Gold Mines of Alburnus Maior ca.107-270 C.E.

by

Heather Ann Pundt

A thesis submitted in partial fulfillment of the requirements for the degree of

\author{
Master of Arts \\ in \\ History
}

Thesis Committee:

Brian Turner, Chair

Caroline Litzenberger

Loren R. Spielman

Linda Walton

Portland State University

(C) 2012 


\begin{abstract}
Trajan conquered Dacia in $106 \mathrm{CE}$ and encouraged one of the largest colonization efforts in the history of the Roman Empire. The new province was rich in natural resources. Immigrants from Dalmatia, Moesia, Noricum, Pannonia, Greece, Syria, Bithynia, Italy, indigenous Dacians, and soldiers from Legio XIII Gemina participated in the extraction of gold from the Apuseni Mountains. The inhabitants of mining settlements around Alburnus Maior and the administrative center Ampelum coexisted under Roman governance but continued to mark their identities in multicultural communities.
\end{abstract}

At Alburnus Maior the presence of wage laborers with access to outside materials and ideas created the opportunity for miners to communicate identity through mediums that have survived. A series of wax tablet legal contracts, altars, and funerary monuments can be combined with recent archaeological data from settlements, burials, and the mines themselves to formulate the broad view necessary to examine the intricacies of group and self-expression. Through this evidence, Alburnus Maior offers a case study for how mobility and colonization in the ancient world could impact identity. Due to the pressures of coping within a multicultural community, miners formed settlements that were central to their daily lives and facilitated the embodiment of state, community, and personal identities.

Identity changes over time and can simultaneously communicate several ideas that are hard to categorize. This study approaches this challenge by looking from macro to micro contexts that influenced several expressions of identity. Chapter 2 begins with a historical background that explores the expansion of the Roman Empire and considers 
how different experiences of conquest influenced the colonists who immigrated to Dacia. The circumstances that led to the massive colonization of Dacia are also considered. Chapter 3 describes how the mines at Alburnus Maior were exploited, who was present, and assesses the impact of state officials, legionaries, and elite entrepreneurs on the formation and expression of state identity through cult, law, and language. The formation of immigrant communities and the working conditions that permeated everyday life at the mines are then considered in the next chapter. Settlement, cult, and religious membership are evaluated for their role in creating and articulating community identities. Chapter 5 then analyzes the personal and sometimes private expression of identity that appears in commemoration, naming conventions, and burial. The three levels of state, community, and personal identities often overlap and collectively show that the hybridization of ideas from several cultures was central to how those at Alburnus Maior negotiated their identity in the Roman Empire. 


\section{Dedication}

For Penelope and Loki 


\section{Table of Contents}

Abstract

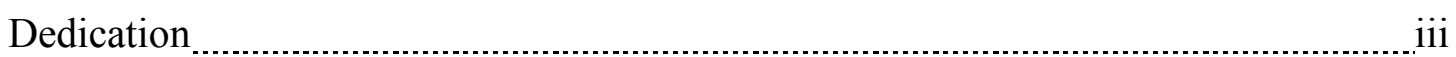

List of Tables _ n vi

List of Figures

List of Abbreviations

Chapter 1

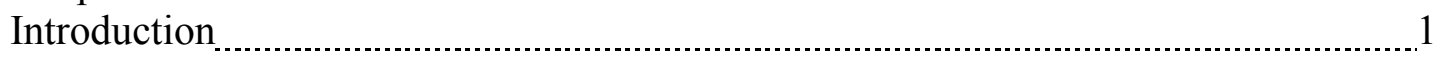

The Sources from Roman Dacia

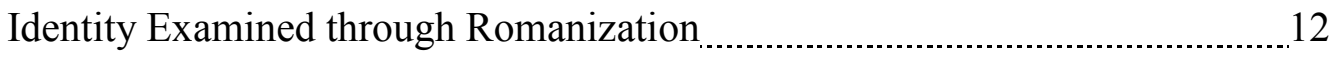

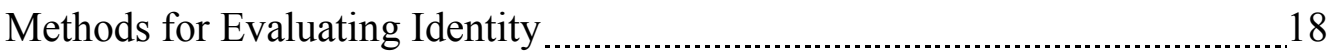

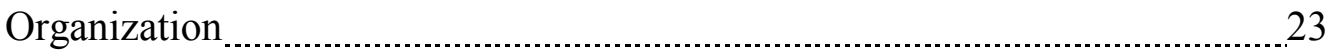

Chapter 2

Historical Background $\ldots \ldots$

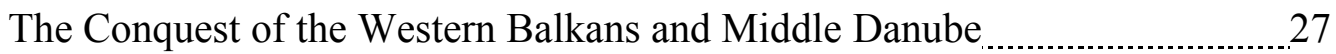

Roman Mining in the First Century CE

The Conquest of Dacia $\ldots \ldots \ldots \ldots \ldots$

Chapter 3

Alburnus Maior in the Roman Empire

State Administration $\ldots \ldots$

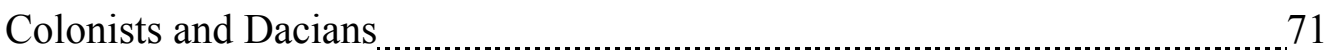

State Identity $\ldots \ldots \ldots$

Chapter 4

Community Identity at Alburnus Maior

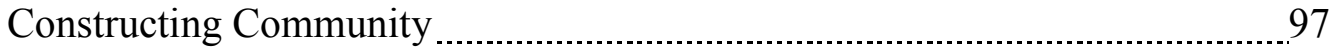


The Mining Experience

104

Community Worship

Chapter 5

"Private" Life at Alburnus Maior

Commemoration and Naming Conventions

Burial Rites

Chapter 6

Conclusion

References 148

Appendices

A. Gods at Alburnus Maior and Ampelum

B. Iupiter Optimus Maximus (I.O.M.) at Alburnus Maior 160

C. Legal Status and Relationships on the Funerary Monuments at Alburnus Maior

D. Regional Map of Danubian Provinces and Dacia

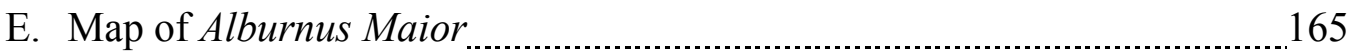

F. Elevation at Alburnus Maior 166

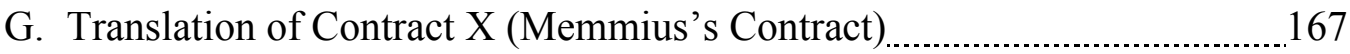




\section{List of Tables}

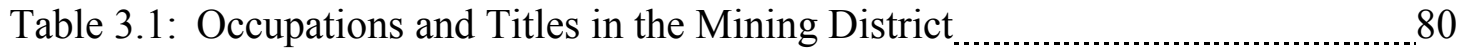

Table 3.2: Contracts and Citizenship Status $\ldots$ 


\section{List of Figures}

Figure 2.1: Maps of Roman Mines in the First Century CE 35 (after Domergue, 2008: map 3, tables 3-7) 


\section{List of Abbreviations}
$\mathrm{AE}$
L'Année Épigraphique
CIL
Corpus Inscriptionum Latinarum
$\mathrm{cIMeC}$
Institutul de Memorie Culturală
d.
died
fl.
flourished
IDR
Inscriptiile Daciei Romane
IGBulg
Inscriptiones Graecae in Bulgaria Repertae
ILD
Inscriptiones Latinae Daciae
ILJug
Inscriptiones Latinae quae in Iugoslavia
IMS
Inscriptions de la Mésie supérieure
$\mathrm{m}$.
modern
r.
reigned
RMGC
Roşia Montană Gold Corporation

Abbreviated classical sources follow the Oxford Classical Dictionary (third edition). 


\section{Chapter 1: Introduction}

On May 19, 164 CE, Memmius, son of Asclepius, contracted to work in the gold mines at Alburnus Maior (m. Roşia Montană, Romania) in Roman Dacia. For six months of labor he would earn seventy denarii and his children another ten denarii. The conductor (contractor), Aurelius Adiutor, agreed to pay the salary intermittently but would fine Memmius five sesterces and eight asses for days he was too sick to work. Additionally, Memmius would not be paid for any unforeseen work delays, specifically if the mines flooded with water. The only condition that protected Memmius's interests was a guarantee of final payment within three days after the contract expired. Despite the conditions favoring the conductor, it was Memmius who hired the scribe to write the Latin contract since he was illiterate. Although of peregrine status, or classified as a foreign resident in the empire, Memmius was determined to protect his limited rights under Roman law. ${ }^{1}$

Ancient authors considered mining the most dangerous, unwholesome, and demeaning labor suitable only for slaves, damnati (criminals), and barbarians. ${ }^{2}$ Yet the prospect of material gain attracted free miners, contractors, skilled experts, and entrepreneurs to mining opportunities throughout the Roman Empire and even beyond its borders. ${ }^{3}$ Gold was especially enticing and created a proverbial 'gold rush' in Hispania,

\footnotetext{
${ }^{1}$ A complete translation of the contract is in Appendix G. CIL III p. 948 Tablet X.

${ }^{2}$ When Xenophon's Socrates refers to mining, he states that the whole region is spoken of poorly and

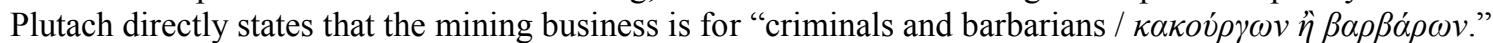
Xen. Mem. 3.6.12 and Plutarch Comp. Nic. Crass. 1.1. As will be discussed in Chapter 3, all three can be considered forms of unfree labor.

${ }^{3}$ The gold mines in Noricum experienced a gold rush before they were officially a province of Rome. In his description, Strabo (4.6.12) notes that groups from Italy were in place well before Roman occupation.
} 
Noricum, Dalmatia, and Dacia. ${ }^{4}$ While some miners panned alluvial soils for gold, others committed themselves to grueling work underground where they faced floods, cave-ins, close quarter fire-setting, and pounding pickax labor. The prevalence of slavery in the ancient Mediterranean supported the assumption that this demanding underground labor was reserved for slaves and convicted criminals. ${ }^{5}$ This general interpretation was challenged by the discovery in 1786 of a fragmented legal document recorded on a waxed wooden tablet suing a conductor for money owed for labor rendered. ${ }^{6}$ The complainants were likely miners as the tablet was found in an abandoned mining gallery at Alburnus Maior. The presence of free wage laborers was substantiated in 1854 and 1855 with the discoveries of Memmius's contract and other similar agreements made by miners who contracted to work in the mines. ${ }^{7}$

These mining laborers were among hundreds who came to the gold rich Apuseni Mountains after the conquest of Dacia in 106 CE. Trajan established a Roman colony at Ulpia Traiana Sarmizegetusa and a legionary base at Apulum to extract resources and maintain a buffer province between the Roman Danube and barbaricum or the foreign lands outside Rome's direct control. The combined effects of Trajan's encouragement

\footnotetext{
${ }^{4}$ Hispania was the Iberian Peninsula while Noricum included modern Austria and the northern part of the Republic of Slovenia. Dalmatia, on the northwest coast of the Balkan Peninsula, covered a region that included the lower half of Slovenia and the countries of Croatia, Bosnia and Herzegovina, Serbia, Montenegro, and the very north of Albania. Finally, Roman Dacia was located in modern Romania, from Transylvania to the Danube River.

${ }^{5}$ This generalization is instilled in part by the frequent observations by ancient authors of slaves at mines in Greece, Asia Minor, Egypt, and Hispania. In the Christian tradition, the sentencing of early Christians to the copper mines of Wadi Faynan in southern Jordan also fuels stereotypes of coerced mining labor in the ancient world. David J. Mattingly, Imperialism, Power and Identity: Experiencing the Roman Empire (Princeton: Princeton University Press, 2011) 190-191.

${ }^{6}$ CIL III p. 933 Tablet IV.

${ }^{7}$ CIL III pp. 948-949 Tablet IX, X, and XI.
} 
and abundant resources invigorated the largest immigration to a new province in the Roman Empire. ${ }^{8}$ The Dacian elite were removed from power after the Second Dacian War (105-106 CE) and Roman colonists quickly claimed the fertile lands of the Mureş Valley (see the Regional Map in Appendix D). The mineral rich Metalliferous range of the Apuseni Mountains was organized under Roman administration by imperial freedmen. The mining procurator stationed in the new settlement of Ampelum leased mine access to immigrant entrepreneurs and their laborers. Throughout the new province, a plethora of colonists from the Danube region and the Italian and Balkan peninsulas interacted with those from Asia Minor and coexisted under Roman administration and law.

The inhabitants of mining settlements around Alburnus Maior and the administrative center Ampelum also created a new community. Migrants from Dalmatia, Noricum, Pannonia, Moesia, Greece, Syria, Bithynia, and Italy, indigenous Dacians, imperial freedmen and soldiers from Legio XIII Gemina participated in the management and extraction of gold. Each group contributed their own perception of what it meant to be part of the Roman Empire. Some already possessed Roman citizenship while others did not gain this legal status until after their immigration to Dacia under the Edict of Caracalla in $212 \mathrm{CE}$ which granted citizenship to all free males in the empire. These peregrine migrants were recognized as foreign residents in the empire and made up the majority of the mining labor. They descended from rural families who had varied exposure to Roman law, the Latin language, and Mediterranean culture. Once in Dacia,

\footnotetext{
${ }^{8}$ Oltean argues that the level of inscriptions and development of towns show the colonization of Dacia was larger and faster than its predecessors further west in provinces like Gaul and Britain. Ioana Oltean, Dacia: Landscape, Colonisation and Romanisation (London: Routledge, 2008) 174-175.
} 
these miners contended with a multicultural community that had a unique awareness of the Roman Empire. Due to the imperial management of the mines, residents were more exposed to Roman administration, law, language, and technology than most other rural areas. The expectations of the imperial fiscus, the impact of the mining industry on daily life, and the diversity of colonists created a type of social stress or tension on the expectations of groups and individuals that fostered adjustments to cope with new ideas and people. Their responses appear in various forms from naming conventions to burial practices and provide unique evidence that illustrates how identity could be negotiated in the Roman Empire.

Since identity fluctuates, trends are more evident when several levels of identity are examined through different expressive forms. At Alburnus Maior, state, community, and individual conscious identities are discernible. These affiliations were expressed in the technologies and symbols utilized in literacy, living space, religion, naming conventions, commemoration, burial, and even methods of labor and production.

\section{The Sources from Roman Dacia}

The evidence from the gold district of Alburnus Maior offers a unique opportunity to evaluate a sample of both elite and labor identity as they negotiated their status in the Roman Empire. Although rural and physically detached from the large urban centers of Roman Dacia, the imperial procurator and his representatives ensured access to popular items and new ideas. From the chance find of legal documents to recent archaeological research, the materials found provide several ways to assess identity. 


\section{$\underline{\text { Roman and Greek Texts }}$}

The observations of mining activity are invaluable to reviewing aspects of daily life. A direct narration of the circumstances at Alburnus Maior does not exist but eyewitness accounts from other mines in the empire provide a clear picture of standard activities and conditions. Pliny the Elder (23/4-79 CE) provides the most detailed account of Roman mining and knowledge of minerals in his Naturalis Historia. As procurator of Hispania Tarraconensis, Pliny had direct access to the gold and silver mines where he observed some of the most intensive mining activity in the empire. Some of his observations were once considered too outlandish, such as the efforts to break an entire mountain with water, but recent archaeology has substantiated the use of such techniques. ${ }^{9}$ His observations were supplemented by his research that he claims included 2000 books. $^{10}$ Other details about mining appear in the $B \imath \beta \lambda \iota 0 \theta \eta \kappa \eta$ (Bibliothēke) by Diodorus Siculus (fl. 60-30 BCE) which includes his observations of mining activity in Egypt. Strabo (64 BCE-ca. $21 \mathrm{CE}$ ) also describes the working conditions in the mines near Pontus in his $\Gamma \varepsilon \omega \gamma \rho \alpha \varphi \imath \alpha$ (Geographia). Finally, the sixteenth century work by Georgius Agricola, De Re Metallica (1556), is often used by historians for its illustrations and descriptions of pre-industrial mining.

Literature about the conquest of the Danube region provides a window into the experience of the colonists who worked in Dacia. Sources that describe the western

\footnotetext{
${ }^{9}$ In this process, ruina montium, miners removed supports from old galleries and adits to weaken the mountain until it fell. Water was also used to wear away the mountain and break it apart and evidence of this was found at the site Las Madulas, a Roman gold mine in Spain. Andrew Wilson, "Machines, Power and the Ancient Economy," The Journal of Roman Studies 92 (2002): 19. For Pliny's description of both techniques see Plin. NH 33.21.

${ }^{10}$ Plin. NH 1.Dedication.
} 
Balkans, the origin of many of the miners, include Pliny the Elder, Strabo, and Appian.

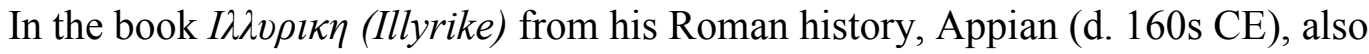
includes a military account of the conquest of this region. Cassius Dio (c.164-post 229 CE) provides the most information about the conquest of both the Danube and Dacia. ${ }^{11}$ As a legate in Dalmatia and Upper Pannonia, Dio had direct military experience that influenced his Roman history. His narrative celebrates the excellence of victorious emperors like Trajan while he openly critiques the failures of others. Despite this bias, Dio's research and access to sources now lost offers a useful history for the region.

These sources provide the framework for discussing a plethora of cultures that are not easily labeled. The names of Roman provinces and dominant culture groups (e.g. Celts or Illyrians) serve as references to discuss the expansion of the Roman Empire. But these names reveal little about the people within those territories. ${ }^{12}$ When a name is considered authentic, the application is often broad. For example, while Pliny the Elder recognized the Illyrians as a specific tribe that lived on the southwest Balkan coast, the term Illyrian is generally used by Roman (and modern) authors to identify collectively all inhabitants of the western Balkans. ${ }^{13}$ The extent of an 'Illyrian' fellowship or identity

\footnotetext{
${ }^{11}$ These sections of his Roman history survive through later epitomes by Xiphilinus (early eleventh century $\mathrm{CE}$ ) and Zonaras (early twelfth century CE). These sources are considered accurate but did include some added material. Zonaras at times followed Xiphilinus over Dio's work and also added in information from other historians such as Eusebius (c. 260-339 CE).

${ }^{12}$ Furthermore, groups that were included in the artificial boundaries of a new Roman province could have little in common while regions now administratively separate may have shared a cohesive identity. For example, the groups in northern Dalmatia shared Celtic La Tène material culture with those in Pannonia before conquest but the borders were created for judicial and military reasons that likely did not take possible community ties into account. Shelley Hales, "Tricks with Mirrors: Remembering the Dead of Noricum," in Material Culture and Social Identities in the Ancient World, eds. Shelley Hales and Tamar Hodos (Cambridge: Cambridge University Press, 2010) 234.

${ }^{13}$ Plin. NH 3.26. In the territory the Romans called Illyricum in the western Balkans at least twenty distinct cultural groups are evident in the material record before the fourth century BCE. John J. Wilkes, The Illyrians (Oxford: Oxford University Press, 1992) 65.
} 
cannot be determined pre-conquest and even groups within the new Roman provinces did not always promote a unified identity. Ancient authors admit uncertainty in the cohesive identity of neighboring peoples. Those the Romans called Daci were identified by the Greeks as part of the Getae who were further considered a branch of the Thracians. ${ }^{14}$ It is likely that these were related tribes who shared language and culture. Strabo separates the groups as related but distinct - the Daci focused westward toward Germany and the Getae faced the Black Sea. ${ }^{15}$ A century later, Cassius Dio suggests that those north and south of the Danube were in fact the same people. In his Roman history, he states, "But I address them as Dacians, just as they are called by both themselves and the Romans, but I am not ignorant that some of the Greeks call them Getae, whether named correctly or not."16 Again, how these groups identified themselves and each other before Roman conquest is not certain. Therefore, although these ethnographic labels provide a framework to evaluate some regional changes, they cannot provide clear answers to questions of ethnicity and self identity since they were created by others.

\section{$\underline{\text { Additional Written Sources }}$}

The discovery of wax coated wooden tablets from inside the mines at Alburnus Maior provides a rare look at the mining community. From 1786-1855, twenty-five tablets were found in several mining galleries. These tablets document legal transactions and purchase orders dating from 131-167 CE. Agreements include loans, employment contracts, the dissolution of a collegium, and purchase orders for food, slaves, and half of

${ }^{14}$ Charles King, The Black Sea: A History (Oxford: Oxford University Press, 2004) 50.

${ }^{15}$ Strabo 7.3.12-13.

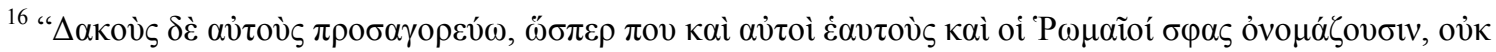

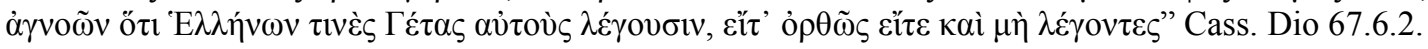

Translations are mine unless stated otherwise. 
a house. The documents were likely hidden during the Marcomannic Wars (166-173 and 177-180 CE) when activity at the mines was disrupted. While mining resumed at Alburnus Maior after the war, these contracts were left in galleries that either flooded or collapsed and remained untouched until their later discoveries. It remains uncertain why they were not retrieved, perhaps parties involved did not return to the mining district or the repossession of the contracts was not necessary since most of the terms for debts and salaries listed had long since expired. Written in Latin (one in Greek), they were slightly less formal than standard Roman contracts. ${ }^{17}$ The contracts were on tablets about $16 \mathrm{~cm}$ x $13 \mathrm{~cm}$ in size and were not for public display but for record purposes. ${ }^{18}$ These documents were not municipal but rather local variations with settlement names associated with Alburnus Maior such as Immenosum Maior (seen in Memmius's contract) and vicus Pirustarum. ${ }^{19}$

Epigraphic evidence is also abundant for this rural community. At least eightytwo religious dedications provide enough text to offer partial and complete translations. Funerary monuments often retain more art than inscription. To date there are seventeen funerary monuments with legible inscriptions. Some were used to pave the entrances to later mining galleries and community structures which removed them from their original

\footnotetext{
${ }^{17}$ This observation is based on the sectioning of the contract which is often absent from these documents. Usually Roman contracts were partitioned into three parts and while some of the longer contracts show this, the majority of the smaller agreements do not. See commentary by Theodor Mommsen, ed., CIL III/2 p. 921-922.

${ }^{18}$ Many of the tablets are in fragments but relatively complete tablets are around this size - Tablet I is $16 \times 13 \mathrm{~cm}, \mathrm{VI}$ is $16 \times 14 \mathrm{~cm}$, and VIII is $19 \times 13 \mathrm{~cm}$.

${ }^{19}$ CIL III pp. 945-947 Tablet VIII and p. 948 Tablet X.
} 
context. $^{20}$ However, enough inscriptions have been found in situ to firmly place these monuments at Alburnus Maior.

\section{$\underline{\text { Archaeology }}$}

Recent archaeological excavations have greatly supplemented the written evidence from the mining region. There is reinvigorated interest in Roman sites in Romania after a hiatus under communist rule which favored Iron Age Dacia (usually focused from King Burebista ca.82 BCE until the Roman conquest in $106 \mathrm{CE}$ ). Although this trend shifted after 1989, this was not before the Roman settlement at Ampelum was destroyed by the construction of a chemical plant. While we do have monuments and some rescue data from this administrative center, most of it is now lost. ${ }^{21}$ The discovery of the wax tablets encouraged interest in Alburnus Maior and archaeologists intermittently studied the area at the end of the nineteenth century and during the 1980s. This area did not suffer the same damage as Ampelum but subsequent mining of the rich region, especially from the 1920s-1980s, and the loss of some finds to fire has taken a toll. ${ }^{22}$ In the 1990s, the Romanian and Canadian partnership Roşia Montană Gold Corporation began the process of reopening the mines. A combined effort by the corporation and the National Union Museum of Alba Iulia and the National Historical

\footnotetext{
${ }^{20}$ Paul Damian, ed., Alburnus Maior I (Bucharest: Muzeul Naţional de Istorie a României, 2003$) 289$.

${ }^{21}$ Rescue archaeology is never ideal as it is often rushed and highly selective. The rescue data from Ampelum was recovered in one season, a very short time for detailed work. For the last report see Alexandru Popa, Vasile Moga, and Radu Ciobanu, "Sapaturile de salvare de la Ampelum (Zlatna) / The Saving Excavations from Ampelum (Zlatna)," Apulum: Acta Musei Apulensis 23 (1986): 105-118.

${ }^{22}$ Although monuments, tools, and jewelry were found by chance during mining exploration and agricultural work, the Museum of Roman Galleries at Roșia Montană suffered a major fire in the 1990s that destroyed some of these earlier finds. Damian, Alburnus Maior I, 28 and 470-471.
} 
Monuments Institute funded new excavations from 1999-2007. ${ }^{23}$ The project marked areas for historical conservation and rescued items from sections that would be lost to mining. The archaeological research provided new data on religious sites, cemeteries, settlements, and the galleries themselves. Wood and charcoal materials found underground were carbon dated to both pre-conquest and Roman mining operations. ${ }^{24}$

\section{$\underline{\text { Past use of these Materials }}$}

Most of these sources are discussed at some length by scholars with focused goals. The literature on mining is used primarily to describe Roman technology or the general experience of miners. ${ }^{25}$ Histories of the conquest of the Danube provinces focus on unraveling the events and politics in the region. ${ }^{26}$ Inscriptions and law codes, like the second century CE lex Metalli Vipascensis from modern Portugal, are used to examine mining administration around the empire. ${ }^{27}$ The wax tablets are reviewed for their legal

\footnotetext{
${ }^{23}$ The intention to use cyanide for mining was largely unpopular and halted by protests in 2007 and the company funded archaeology ended. Damian, Alburnus Maior I, 9 and RMGC http://en.rmgc.ro/rosiamontana-project/patrimony/archeological-research/benefits-of-rosia-montana-project.html (accessed December 14, 2011). New permits were awarded in 2010 and protesters are still busy with activities as recent as December 2, 2011. http://rosiamontana.org/en/index.shtml (accessed December 14, 2011).

${ }^{24}$ Damian, Alburnus Maior I, 472.

${ }^{25}$ Arguably the earliest study with a focused interest in mining history and techniques that uses Roman sources is Georgius Agricola's De re metallica (1556). The first complete overview of Roman mining was Oliver Davies's Roman Mines in Europe (1935). Claude Domergue combines this approach with archaeology in his recent Les Mines Antiques (2008).

${ }^{26}$ John Wilkes updated his 1969 dissertation on Dalmatia in The Illyrians (1992) which provides a narrative of the region. Vasile Lica's The Coming of Rome in the Dacian World (2000) uses these sources to examine Roman policy and politics. Also, although focused on the artwork of Trajan's Column, Lino Rossi's Trajan's Column and the Dacian Wars (1971) and Leppard and Sheppard's Trajan's Column: A New Edition of the Cichorius Plates (1988) rely heavily on these literary sources to build their histories.

${ }^{27}$ A recent comprehensive study on mining administration is Alfred Hirt's Imperial Mines and Quarries in the Roman World (2010). Several articles by Slobodon Dušanić also examine the role of mining procuratores, especially in the Danube provinces (see references).
} 
content and names. ${ }^{28}$ Further onomastics of the epigraphic data are directed towards determining origin and legal status. ${ }^{29}$ Finally, the archaeological data, still new and developing, is focused on organizing and identifying local sites. ${ }^{30}$

The basis for a comprehensive examination of the formation and expression of identity is available through these sources. Yet none of these elements have been combined in a study that brings these pieces together into a larger narrative. The Roman and Greek literature provides a foundation for understanding aspects of the miners' experience of conquest. The observations also help solidify an image of the mining and living conditions that permeated daily life. This is supplemented by archaeology which also provides further information about public religious space as well as private burial. Finally, the wax contracts and epigraphic data illustrate how status and identity was expressed in both private and public documents. All of these elements are not perfect as they cannot speak for every miner or experience at Alburnus Maior. But these sources provide enough information to formulate a working example of how multifaceted identities were expressed in at least one unique immigrant community.

\footnotetext{
${ }^{28}$ Hans-Christoph Noeske's "Studien zur Verwaltung und Bevölkerung der dakischen Goldbergwerke," (1977) is the most comprehensive example still used by many scholars today. A study focused primarily on the legal use of some of the contracts was done by Valeriu Sotropa in Le droit Romain en Dacie (1990).

29 The most recent of these, Ex toto orbe Romano: Immigration into Roman Dacia With Prosopographical Observations on the Population of Dacia by L. Mihailescu-Birliba (2011) was unfortunately not included in this study due to its recent availability. In other epigraphic studies there is the frequent focus on citizenship and origin. Tracking origin is complicated by the popularity of names outside expected regions and disagreements in identifying ethnicity between names such as Dacian or Thracian and Illyrian or Celtic is common. For example, while Romanian scholars such as John Macrea, Ioan I. Russu, and C.C. Petolescu view Laterculus to be Dacian others such as A. Dabó and G. Alföldy view it as Thracian. Cosmin Onofrei, "Thracians in Roman Dacia. Military and Civilian Elements," Ephemeris Napocensis 28 (2008): 79. Meanwhile, Wilkes notes a similar disagreement surrounding Liburnian names from the west coast of Dalmatia - some view these names as Illyrian while others state they have more in common with Italic and Celtic names because of the common ending -icus. John J. Wilkes, Dalmatia (Cambridge: Harvard University Press, 1969) 161.

${ }^{30}$ Several archaeological reports edited by Paul Damian in Alburnus Maior I (2003) and subsequent studies edited by Mihaela Simion in Alburnus Maior II (2006) provide some recent examples.
} 


\section{Identity Examined through Romanization}

The expansion of the Roman Empire encouraged an exchange of ideas and intensified trade that impacted community and individual identity. In previous histories, the level of acceptance and use of Roman culture by the conquered, or their Romanization, was the focus for understanding the fashioning of provincial identities. However, these changes are not consistent throughout the empire or even within local communities. The influence of imperialism and the reality of increased mobility created variables that further complicate the narrative offered by Romanization alone.

\section{$\underline{\text { Romanization }}$}

Romanization was once the popular approach used by historians and archaeologists to examine indigenous culture change after conquest by the Roman Empire. Theodor Mommsen first used the term "Romanization" in the late nineteenth century that was later popularized by Francis Haverfield in the Romanization of Britain to explain the change in conquered societies towards Roman ideas. ${ }^{31}$ Similar terms have been used to express the linear impact of a dominant culture on others such as Hellenization by the Greek states and the pre-conquest Dacianization of their neighbors. ${ }^{32}$ Historians of Roman Britain and other western provinces have predominantly eliminated the term Romanization from their discussions of these regions, while many histories of Roman Dacia, Moesia, Pannonia, and Dalmatia still describe these provinces

\footnotetext{
${ }^{31}$ Mattingly, Power and Identity, 205.

${ }^{32}$ For example, Dacianization is used to describe the cultural changes in Celtic areas of Pannonia and the territory of the Iazyges west of Burebista's kingdom that were conquered for a short time. András Mócsy, Pannonia and Upper Moesia: A History of the Middle Danube Provinces of the Roman Empire, trans. Sheppard Frere (London: Routledge, 1974) 19 and 57.
} 
as models of Roman acculturation. ${ }^{33}$ One of the greatest problems with this approach is that it negates or ignores the influences the Danube provinces had on each other which occurred both before and during Roman occupation. ${ }^{34}$ Indeed, the various ideas of what was Roman were often introduced from neighboring provinces rather than the city of Rome. ${ }^{35}$ This is especially true for Roman Dacia where an influx of immigrants did not bring acquired static Roman ideas but a reality of a flexible Mediterranean culture.

The level of Roman acculturation in Dacia, and the consistency of that influence after Roman withdrawal, retained longevity in Romanian history as an aspect of national identity. Contemporary political and cultural perceptions of Roman history may influence the continued use of Romanization and the preference for evaluating degrees of "Romanness." The Romans conquered Dacia in $106 \mathrm{CE}$ and abandoned the province during 271-275 CE under Aurelian. ${ }^{36}$ In 170 years of occupation, Rome never acquired the full region of modern Romania and many Dacians lived outside Roman territory as

\footnotetext{
${ }^{33}$ A few recent examples: Dzino, Illyricum in Roman Politics 229BC-AD68 (2010); Alföldy-Găzdac et al, "Project 'Necropolis Porolissensis' Methods and Perspectives" (2007); Simion et al, Alburnus Maior II (2005); Damian et al, Alburnus Maior I (2003); Jovanović, "Romanization and ethnic elements in burial practice" (2000); Lica, The Coming of Rome in the Dacian World (2000); Topál, "The connection between funerary rites and ethnic groups" (2000).

${ }^{34}$ An example appears in Stefan's focus on the Hellenization of the Dacian kingdom over Celtic influences in Late Iron Age Roman Dacia. For a discussion see Everett L. Wheeler, "Rome's Dacian Wars: Domitian, Trajan, and Strategy on the Danube, Part I," The Journal of Military History 74 (2010): 1213.

${ }^{35}$ If the city of Rome can even be interpreted as the most "Roman" or culturally consistent throughout the empire's history.

${ }^{36}$ The legions were first removed in $271 \mathrm{CE}$ and did not return to their Dacian stations. The Ostrogoths then occupied the most northern region, Dacia Porolissensis, in $275 \mathrm{CE}$ and there is little sign of displacement or disruption of Roman and Dacian settlements. A. Diaconescu, "The Towns of Roman Dacia: An Overview of Recent Archaeological Research," in Roman Dacia: The making of a Provincial Society, eds. W.S. Hanson and Ian Haynes (Portsmouth: Journal of Roman Archaeology, 2004) 129-130. Nonetheless, the province of Dacia continued to exist in the Roman Empire as a new area was carved out of Moesia Superior and Inferior south of the Danube to make room for the province. The Romans could not lose territory and the retention of Dacia was important to the psyche of the empire. Joonas Sipilä, The Reoganisation of Provincial Territories in Light of the Imperial Decision-Making Process: Later Roman Arabia and Tres Palaestinae as Case Studies (Helsinki: Societas Scientiarum Fennica, 2009) 21.
} 
"free Dacians" who came alternatively as refugees and raiders into the province. ${ }^{37}$ It is uncertain how many free Dacians and Roman colonists remained behind when Rome left and the initial nature of their partnership with new migrants such as the Ostrogoths is unknown. Nonetheless, Romanian is a romantic language derived from Latin and is largely associated with the Latin speaking colonists and Dacians who remained in Dacia after Roman withdrawal.

The longevity of Latin-based Romanian became part of the ethnic identity of the region which experienced Byzantine, Ottoman, Habsburg, Romanov, and Soviet empires that often redrew the Romanian borders. ${ }^{38}$ The possession of Transylvania was debated from the fall of Ottoman control in the eighteenth century until the Treaty of Paris in 1947. Arguments focused on the establishment of historical ethnic continuity: the Austro-Hungarians argued the land had been abandoned before Hungarian and Saxon settlement while the Romanians asserted the linguistic and cultural traditions of the region dated back to Roman colonization. ${ }^{39}$ Under Soviet rule in the 1950 s a policy of "de-Romanization" included the state enforced categorization of Romanian as a Slavic language and abandonment of research on Roman sites. ${ }^{40}$ The Roman occupation of

\footnotetext{
${ }^{37}$ Roger Batty, Rome and the Nomads: The Pontic-Danube Realm in Antiquity (Oxford: Oxford University Press, 2007) 365-366.

${ }^{38}$ The nationalist movement celebrated Roman ties and even reintroduced some Latin words into the Romanian language during the late nineteenth century. However, the language is still clearly connected with Latin even outside these efforts. Julian Bennett, Trajan: Optimus Princeps: A Life and Times (Bloomington: Indiana University Press, 1997) 172.

${ }^{39}$ L. Ellis, “"Terra Desert': Population, Politics and the [de]Colonization of Dacia,” World Archaeology. Population and Demography Series 30, no. 2 (1998): 220 and 222-224. These arguments resurfaced in the 1970s thru the 1980s with Hungarian historians then arguing that Roman settlers evacuated the province under Aurelian but migrated north across the Danube at a later date. Oltean, Dacia, 6.

${ }^{40}$ During the 1950s linguists at Romanian universities were threatened with time at labor camps if they did not recognize Romanian as Slavic. Ellis, “"Terra Desert,”" 224-225. Anyone who proposed projects on
} 
Dacia was recast as "oppressive imperialism" which used slaves and the lower classes to pillage the country. ${ }^{41}$ Under the dictatorship of Nicolae Ceausescu (1965-1989), the preRoman Dacian state was celebrated and research of the Late Iron Age kingdoms of Burebista and Decebalus were encouraged. In 1980 there was a national celebration of 2050 years of a unified Dacian state. ${ }^{42}$ Since the December Revolution of 1989 which ended Ceausescu's communist rule, there are new projects that examine both Dacian and Roman history. Despite communist efforts, the national conscience still associates Romanian identity with their Roman history. It is possible this national pride promotes the longevity of Romanization in research while it loses favor in studies of other provinces.

\section{The Impact of Empire and Conquest}

The elimination of Romanization as an analytical premise should not negate the impact of the Roman Empire on conquered regions. Military actions, imperial decisions, civil administration, new laws and processes, and even a commercialization of culture caused some levels of change in new provinces. Because these experiences were not consistent from one region to the next, an examination that allows for shifting imperialism and colonialism is better suited to the reality of transformation under the

Roman Dacia were accused of maintaining an interest in "bourgeois values." Diaconescu, "Towns of Roman Dacia," 87.

${ }^{41}$ Oltean, Dacia, 5.

42 Ellis, "“Terra Desert,"” 225. During the same celebrations, Romania also hosted an International Congress of Historical Sciences. Wheeler, "Dacian Wars,"1187. 
empire. ${ }^{43}$ Indeed, the idea of Roman imperialism has been challenged because of its lack of cohesion as a policy of expansion. ${ }^{44}$

There were real limitations on the amount of influence the Roman center had on the entirety of its new provinces in the periphery. Regions such as the Balkan Peninsula experienced post-conquest imperial tendencies that varied from one region to the next. When administrative independence was encouraged, handpicked local elites served as intermediaries who maintained their own local power by promoting Roman governance and organizing Roman taxation. Some indigenous elites were denied leadership immediately after conquest. To encourage easier governance by Roman representatives, groups who had resisted were purposefully separated and moved within the new province. This strategy did not often entice indigenous participation in civic life, and military bases and colonies remained isolated in these areas. In reality, the provincial borders were limited by the governor's ability to formalize power beyond urban and military centers. ${ }^{45}$ Thus, the Roman Empire was established, but the intensity of this presence was inconsistent from one region to the next. This shifting imperialism and colonialism in the provinces is useful for understanding the experience of conquest under an empire that did not expand under a consistent policy.

In Roman Dacia, the local elite were removed from power and colonists drove change in the province where new immigrant elites forged the public norms. ${ }^{46}$ However,

\footnotetext{
${ }^{43}$ Mattingly suggests that instead of examining Roman imperialism, imperialisms more adequately describe the "shape-shifting" power relationships. Mattingly, Power and Identity, 17.

${ }^{44}$ Sipilä, Reorganization of Provincial Territories, 5-7.

${ }^{45}$ Sipilä, Reorganization of Provincial Territories, 14.

${ }^{46}$ According to recent studies, Dacian names only appear in 2-3\% of the epigraphic record. Oltean places this number at $2 \%$ but Ruscu has the figure above 3\%. I.A. Oltean, "Rural Settlement in Roman Dacia:
} 
this is where Dacia also becomes problematic. The settlers came from different experiences of the Roman Empire in their home regions. Some were conquered through diplomacy, such as the absorption of the client-kingdom of Noricum, while others had a long history of violent conflict with the Romans, as seen in the interior regions of Dalmatia. Their experience with the empire was further intensified by the active role of Roman administrators in provincial life, especially in the control of imperial mines. Thus, Dacia is better seen under the guise of shifting power forms: the conquest and military occupation by empire, the indirect imperial control of the economy and resources, and the colonial presence that reordered the territory under new elites. ${ }^{47}$ Mobility

Power relationships and change in Roman Dacia cannot be fully understood without considering the influence of mobility in the ancient world. Although past explanations of change induced purely by group migration have been justifiably discarded, discussions that examine peoples as fixed populations are also incorrect. ${ }^{48}$ The movement of traders, craftsmen, soldiers, and families existed in both Iron Age and

Some Considerations," in Roman Dacia: The making of a Provincial Society, eds. W.S. Hanson and Ian Haynes (Portsmouth: Journal of Roman Archaeology, 2004) 152 and D. Ruscu, "The Supposed Extermination of the Dacians: The Literary Tradition," in Roman Dacia: The making of a Provincial Society, eds. W.S. Hanson and Ian Haynes (Portsmouth: Journal of Roman Archaeology, 2004) 78.

${ }^{47}$ This is largely adopted from Mattingly's discussion on the different roles of empire, imperialism and colonialism seen in the ancient world and Bartel's case study of Moesia Superior which examines the shifting "power and domination" realities under colonialism and imperialism. Mattingly, Power and Identity, 6-7 and Brad Bartel, "Acculturation and Ethnicity in Roman Moesia Superior," in Centre and Periphery Comparative Studies in Archaeology, ed. Tim Champion (Hoboken: Routledge, 1995) 174.

${ }^{48}$ Peter S. Wells, Beyond Celts, Germans and Scythians (London: Duckworth, 2001) 8. Archaeologists responded to earlier criticism against migrations by halting any consideration of people moving and concentrated instead on the exchange of ideas. Now movement is again seen in Iron Age Europe but with a population that more often "crawled" with instances of smaller communities and individuals moving greater distances. Batty, Rome and the Nomads, 14-15. 
Roman communities. ${ }^{49}$ This movement was intensified under the Roman Empire with the organization of garrisons and exploitation of resources. ${ }^{50}$ Utilizing new roads, the empire not only strategically positioned soldiers to protect Roman interests but also intentionally relocated entire populations from one province to another to supply labor and expertise. The latter comprised the settlement of Roman veterans in conquered territories but could also include indigenous communities utilized for activities such as mining. This mobility is evident in Dacia where immediately after conquest the majority of mining laborers came as groups rather than individuals. Most of these miners were of peregrine status and as protected foreigners were free to travel within a territory but it is likely they had to obtain legal permission to move between provinces. ${ }^{51}$ Therefore, the momentum of Roman conquest and provincial development often increased the mobility of ideas as well as individuals which directly influenced expressions of identity.

\section{Methods for Evaluating Identity}

The pressures of negotiating status after conquest combined with the social stress of increasingly diverse communities make identity an important point of inquiry. Since the 1980s the concept of identity has gained popularity in first archaeology and then historical studies for evaluating how groups and individuals distinguished themselves in

\footnotetext{
${ }^{49}$ Ray Laurence, "The Creation of Geography: An Interpretation of Roman Britain," in Travel and Geography in the Roman Empire (London: Routledge, 2001) 67 and 91. Epigraphic evidence is still used to track some movement of populations in the Roman Empire that is supplemented by the recent use of isotope data which provides examples of long distance travel. H. Eckardt et al., "A Long Way from Home: Diaspora Communities in Roman Britain," in Travel and Geography in the Roman Empire (London: Routledge, 2001) 104 and 112.

${ }^{50}$ By Augustus there was a "systematically organized flow of goods from the Mediterranean to the frontier garrisons" to support Roman interests and expansion. Michael Fulford, "Territorial Expansion and the Roman Empire," Archaeology of Empires 23 (1992): 296.

${ }^{51}$ This is clearly documented in Egypt where a diploma was required to leave the province. However, provincial rules varied and the legal status peregrini likely had a greater impact on the movement of miners. Moatti, "Translation, Migration and Communication," 125 and 118-119.
} 
ancient society. ${ }^{52}$ In part identity replaces ethnic and cultural narratives that looked for "distinct peoples" who were viewed as homogeneous groups in "bounded monolithic territorial entities."53 This tendency was often encouraged by ancient sources where there is evidence that indigenous groups began to adopt Roman and Greek labels, such as Celt or Gaul, as part of their group identity in response to their interactions with Mediterranean culture. ${ }^{54}$ In searching for these cultures, archaeologists associated material culture with specific ethnic groups while historians examined texts for tribal names and clues to their locations. The combination of these approaches created metanarratives that often ignored the inconsistencies present in the evidence.

Material culture does not provide a clear testament to ethnicity but can be used to survey expressions of identity. Archaeologist Siân Jones evaluates the social life of material culture by examining a large selection of items from a "bird's eye view" that includes several archaeological sites that overlap cultural boundaries. Jones argues that diverse samples can then lead to a better understanding of how material culture was used

\footnotetext{
${ }^{52}$ Tamar Hodos, "Local and Global Perspectives in the Study of Social and Cultural Identities," in Material Culture and Social Identities in the Ancient World, eds. Shelley Hales and Tamar Hodos (Cambridge: Cambridge University Press, 2010) 8 . Historians began writing more about identity in the 1990s with an increase after 2000 as a means to replace Romanization. Martin Pitts, "The Emperor's New Clothes? The Utility of Identity in Roman Archaeology," American Journal of Archaeology 111 (2007): 693-694.

${ }^{53}$ As further illustration of the complexity of ethnic identity, Jones states, "ethnic identity is based on shifting, situational, subjective identifications of self and others, which are rooted in ongoing daily practice and historical experience, but also subject to transformation and discontinuity." Siân Jones, The Archaeology of Ethnicity: Constructing Identities in the Past and Present (London: Routledge, 1997) 1314, 48 and 110 and David Mattingly, "Cultural Crossovers: Global and Local Identities in the Classical World," in Material Culture and Social Identities in the Ancient World, eds. Shelley Hales and Tamar Hodos (Cambridge: Cambridge University Press, 2010) 288.

${ }^{54}$ Wells, Beyond Celts, 32 and 104. Noted more in anthropology, as different groups interact, they tend to simplify their own image in order to promote a stronger unified picture to others. Hodos, "Social and Cultural Identities," 17.
} 
in social practice. ${ }^{55}$ Material culture from daily practice, such as cooking or dress, can be evaluated along with more specific manifestations of identity such as the dedications of religious monuments. ${ }^{56}$ This approach can also be used to examine immigrant communities where responses to new people, environs, and ideas often amplified the desire to express social identities. But immigrant communities were not always wealthy and the availability of materials could limit and adjust their expressions of identity. The extent to which an individual or community was able to participate was influenced by their physical, economic, and social access to items. Therefore, Jones's comprehensive approach that includes every day and non-elite items also provides a means for examining several strata within a society.

Studies in identity incorporate a plethora of sources which often encourages the recognition of new hybrid cultural identities. Evidence may include art, architecture, settlement, inscriptions, literature, monument, burial, pottery and other objects. All of these items provide a better understanding of the "lived experience" and patterns can be used as markers of identity. ${ }^{57}$ The communication of identity is present in both the intention of an individual and the influences present that stimulate action subconsciously. While the message may not always be clear, the product of making the statement, such as

${ }^{55}$ Jones, Archaeology of Ethnicity, 88 and 100.

${ }^{56}$ For daily practice Jones builds off Pierre Bourdieu's concept of habitus that focuses on the common practices in daily life which can create unconscious expectations of normal behavior. This approach has been successfully used in recent ancient histories to examine how imposed changes in routine can also create social norms. For example, in her recent evaluation of the Roman military, Phang uses this concept of habitus to show how routine created discipline (disciplina) and played a larger role in instilling expected behavior and hierarchy than prescriptive actions like participation in the imperial cult. Sara Elise Phang, Roman Military Service: Ideologies of Discipline in the late Republic and early Principate (Cambridge: Cambridge University Press, 2008) 27 and 31.

${ }^{57}$ Carla M. Antonaccio, “(Re)defining Ethnicity: Culture, Material Culture, and Identity," in Material Culture and Social Identities in the Ancient World, eds. Shelley Hales and Tamar Hodos (Cambridge: Cambridge University Press, 2010) 38. 
an elaborate funerary monument, provides an opportunity to examine choices to act. Likewise, the presence of new influences, such as the access to common goods, offers clues to the conditions that induced change. These approaches do not give the full story and the conclusions are not always applicable to everyone in the community. Instead, several types of evidence can be pieced together to create an overall picture. Time and again this diversity indicates that a hybrid culture replaced Roman, native, immigrant, and other groups in-between as none of them maintained static forms. ${ }^{58}$ Hybridization is used to describe this complex process of molding these new identities. The use of discrepant identities proposed by David Mattingly provides a more inclusive definition which takes into consideration the marginalization of groups and the "inharmonious aspects" of identities formed under empire. ${ }^{59}$ Not every group had access (whether physically, economically, or legally) to the changes under the empire and expressions of new identities could be limited by inequalities.

The utilization of several sources also responds to the real challenges created by the fluidity in identity and lack of clear distinctions in the evidence. Conductores (managers), mining specialists (e.g. engineers), miners (those who picked, sorted, washed, or smelted ores), and slaves lived at Alburnus Maior but did not find it necessary to record their exact occupation. For example, Memmius's contract is signed by two witnesses without a title. But in two other contracts these same men are identified with the title conductor. Evidence for this type of comparison is rare at Alburnus Maior. Additionally, although conductor appears in the wax tablet contracts, the title is not found

\footnotetext{
${ }^{58}$ Hodos, "Social and Cultural Identities," 4 and 21. Oltean, Dacia, 17-18.

${ }^{59}$ Mattingly, Power and Identity, 213.
} 
on any of the inscriptions at Alburnus Maior. They were heavily involved in the direction of activities at the mines and were undoubtedly involved in the communities where they lived. Therefore, it is not always possible to discern a person's occupation which would have influenced their status and income. This restricts some research questions and encourages a more collective approach. For this case study, the 'mining district' refers to all involved from state officials at Ampelum to the miners underground. The 'mining community' includes all who worked and lived at Alburnus Maior which included conductores to slaves. The general occupation 'miner' can only be limited to those who performed the physical labor and includes wage laborers as well as slaves. These inclusive terms provide a means to categorize participants in the mining industry that is not always apparent in the evidence.

The final challenge with identity is that while it highlights the disparate local narrative and experience, the study can become victim to the multifaceted reality of different levels of expression that diminishes into a narrative of "diversity for diversity's sake. ${ }^{, 60}$ Although modern social categories carry some assumptions and separations not defined in the ancient world, it helps to assign divisions for understanding the many aspects of identity. ${ }^{61}$ Patterns appear in expressions of government association, origin, status, wealth, employment, law, language, literacy, location, religion, and gender. ${ }^{62}$ Additionally, focusing on diverse groups that share some commonality in either the formation of a unique community and/or similar access to ideas and goods can help

\footnotetext{
${ }^{60}$ Pitts, "Identity in Roman Archaeology," 696.

${ }^{61}$ For example, terms like 'economy' are often more mixed in Roman and Iron Age societies and might include political and social relationships beyond our normal definitions. Wells, Beyond Celts, 16.

${ }^{62}$ Part of a long list suggested by Mattingly. Mattingly, Power and Identity, 217.
} 
create a framework for understanding the development of identity. ${ }^{63}$ The mining community at Alburnus Maior provides a case study with most of these conditions.

The mining district at Alburnus Maior was a unique rural community that balanced pressures from the imperial fiscus with the realities of the mining experience. Here colonists from different regions of the empire forged new communities and identities which are apparent in evidence ranging from written contracts to burial rites. At Alburnus Maior the hybridization of several cultural ideas forged identities that expressed association with the Roman Empire, defined membership within the local communities, and balanced these influences with individual expectations.

\section{Organization}

Identities at mining communities were formed by the realities of the industry as well as the conditions that encouraged immigrants to the region. In order to study these influences it is beneficial to review the larger historical narrative of the region before examining the public and private developments within the district.

Chapter 2 provides a historical background that focuses on events and circumstances that indirectly impacted the development of the Roman mines at Alburnus Maior. A brief evaluation of the incorporation of the western Balkan Peninsula into the Roman Empire highlights the experiences that influenced how immigrant miners created community and expressed identity. The drive to secure material resources is well evident in this region and others by the end of the first century $\mathrm{CE}$ and this economic influence on Roman expansion is also examined. Finally, the historical background to the conquest

\footnotetext{
${ }^{63}$ Pitts notes the papers on identity that are the most successful are those that include diversity within a unique community such as the military. Pitts, "Identity in Roman Archaeology," 697.
} 
of Dacia and the structuring of the new province shows how long standing disputes fueled the marginalization of the indigenous elite and created a vacuum of opportunity for immigrants. The massive colonization in Roman Dacia directly influenced the variety of Roman goods and ideas in the communities closest to the mining district.

In Chapter 3, the administrative structure and strong public presence of the imperial procurator and his staff, the military, and other elite are evaluated. Mining regulations influenced labor and restricted access while the organization of imports and personnel also affected daily life. The various members of the mining district ranged in status and duties which balanced the needs of the local community with the desires of the state. In this public sphere, the ways the mining community expressed affiliation with the empire and how miners adjusted to Roman laws and language will also be examined.

The following chapter will consider the physical realities of mining labor as well as the daily conditions of living in these communities. The distinct settlement patterns and community names provide a glimpse at how local membership was forged. The dangerous industry undoubtedly impacted which gods were worshiped while the wages earned facilitated the expression of religious belief and membership.

Finally, Chapter 5 examines the importance of familial and tribal ties maintained in commemoration and burial. While these more local and personal expressions of identity are difficult to outline with certainty, there is data to suggest plausible patterns that illustrate how miners embraced aspects of a Roman identity but maintained markers unique to their community and family.

Therefore, a larger view of conquest will gradually focus on public and private expressions of identity in a unique immigrant community. This case study illustrates how 
expressions of state, community, and personal identities often overlap and collectively show that the hybridization of ideas from several cultures was central to how those at Alburnus Maior negotiated their identity. 


\section{Chapter 2: Historical Background}

The miners who worked the Apuseni Mountains in Dacia for the Roman Empire came from different provinces and experienced diverse social change before they immigrated. The lack of a direct policy of expansion and the varied reactions of indigenous groups created disparate forms of conquest. A single narrative of how groups were incorporated into the empire is not possible and carefully constructed regional histories that address the several aspects of conquest quickly become complex. Examples that illustrate the political conversion of client kingdoms and the violent conquest of others offer a basis for identifying some common aspects of imperialism experienced in this region. A case study focused on Dalmatia illustrates how Roman expansion included both political conversion and violent conquest wherein the indigenous elite retained varied levels of local power. Although all of these indigenous groups experienced change under new Roman models of administration, such as taxation, the degree of continuity in local leadership affected the exercise of indigenous legal rights and settlement. Indigenous groups stripped of their local leaders were occasionally subject to forced relocation as laborers to work in imperial mines. A short evaluation of the Roman mines during the first century CE illustrates how the empire used conquest to meet the growing demand for metals.

The conquest of Dacia and colonization of the province provides another unique narrative of Roman expansion and explores further the importance of resources to the growing empire. This kingdom had a contentious history with Rome and was perceived as a continued threat to the empire's interests. By the time Dacia was conquered at the start of the second century CE, most of the western Balkan and Danube provinces had 
been under Roman rule for almost a century. Colonists from these regions would bring their past experiences to create new immigrant communities in one of the largest colonization efforts of the empire.

\section{The Conquest of the Western Balkans and Middle Danube}

The Balkan and Danube provinces that were the most influential in the colonization of Roman Dacia were Noricum, Pannonia, Dalmatia, and Moesia Superior (see Regional Map in Appendix D). To the north of these provinces, the Danube River created an artificial limes, or boundary to the Roman Empire, that followed the river from its origin in modern Germany to the Black Sea. ${ }^{64}$ Within the provinces were rich mineral resources of iron, silver, gold, and lead. The Alps dominated Noricum and the Dinaric Alps split Dalmatia into a coastal and mountainous province. Moesia Superior was mostly mountainous lying where the Dinaric Alps and the Balkan Mountains meet.

The Danube and Balkan regions interacted through trade networks that were influential in creating contacts and challenging identity long before Roman occupation. The movement of merchants, establishment of colonies, and immigration of peoples to new centers of opportunity encouraged awareness of other cultures around Europe. The Aegean and Adriatic Seas as well as the Danube River facilitated this exchange which began as early as ca.1500 BCE along the Amber Trade Route. ${ }^{65}$ The western Balkan

\footnotetext{
${ }^{64}$ The Danube limes was not a permanent fixture and territories north of the river were also brought under imperial influence if not lasting control. Dacia provides one of the most prominent examples. Full occupation was not required for Roman influence. For example, new archaeological evidence near Mušov, Czech Republic points to Roman camps and extensive trade in areas north of the Danube which were not part of the empire proper. J. Tejral, "The Roman Military Impact and the Natives North of the Middle Danube During the 1st centuries AD," in Roman Frontier Studies 1995: Proceedings of the XVIth International Congress of Roman Frontier Studies, ed. Willy Groenman-Van Waateringe (Oxford: Oxbow, 1997) 535-536.

${ }^{65}$ The Amber Route from the Baltic to the Adriatic Seas connected populations of the Balkan Peninsula and along the Danube River in trade.
} 
coast was already importing, processing, and eventually mining copper, tin, and gold from the tenth to eighth centuries BCE which likely influenced the trade across the Adriatic Sea. ${ }^{66}$ This trade intensified after the seventh century BCE as amber was especially popular on the Italian peninsula for both decorative embellishment and medicine. ${ }^{67}$ Evidence of hybridization is seen in modified urban structures that were inspired by models from Greek colonies as early as the fourth century BCE.

Construction technologies, such as tiled roofs, also appear piecemeal in the archeological record in places like the settlement at Radovin in modern Croatia. However, the layout of this city did not change and the idea of public and monumental architecture did not accompany the import of Greek building techniques. ${ }^{68}$ The Roman Empire did intensify the interactions of disparate groups and force them to further shape new identities. But evidence of pre-conquest trade suggests that many of these groups were already participating in the Mediterranean exchange for their own benefit and adjusting identities in response to these contacts.

The incorporation of these areas as provinces of the Roman Empire began in the first century BCE. Each area experienced conquest differently. Some areas, such as the Norican kingdom in the Alps and the coastal region of Liburnia in Dalmatia were established before the end of the first century BCE as a result of protecting and absorbing client-kingdoms and territories. Other regions, especially the more mountainous areas of

\footnotetext{
${ }^{66}$ An increasing presence of tumulus tombs near mineral sources may indicate some movement towards mining areas in mountainous regions. Wilkes, Illyrians, 35-37 and 58.

${ }^{67}$ John Boardman, The Greeks Overseas: Their Early Colonies and Trade (London: Thames and Hudson, 1980) 235 and Wilkes, Illyrians, 35-37. Although during the first century CE, the account by Pliny the Elder attests to the continued popularity of amber as a well carved piece was worth more than a slave. Amber also had several medicinal uses from lowering fevers to curing stomach diseases. Plin. NH 37.12.

${ }^{68}$ Wilkes, Illyrians, 126-127 and 188.
} 
Dalmatia and Moesia Superior, were conquered through violent conquest that often created scattered and incomplete occupation until the end of the first century CE. The different experiences of conquest in these regions directly influenced the colonists who immigrated into Dacia. Two case studies from the eventual province of Dalmatia provide examples of both of these forms of political and violent conquest.

The contact between the Romans and the people of the western Balkans intensified in 299 BCE when the Romans first invaded the land they called Illyricum across the Adriatic Sea. A disruption in trade encouraged Roman intervention. According to the Greek historian Polybius, King Agron unsettled the area as he expanded his kingdom in the western Balkans and in 232/1 BCE attacked Roman allies. After Agron's death, his queen, Teuta, encouraged attacks along the Adriatic Sea. The Romans viewed this as piracy that further threatened their trade routes. The Roman Senate approved military action after an envoy was killed at Teuta's court and this conflict was known as the First Illyrian War. ${ }^{69}$ The Greek cities Epidamnus, Apollonia and Corcyra were "liberated" by Rome in 229 BCE and Queen Teuta surrendered and agreed to pay tribute a year later while additional mainland kingdoms also became client-kings to Rome. ${ }^{70}$ These mainland kingdoms were now under the protectorate of Rome and as client-kings their political status changed to one of unequal but mutual partnership.

The client-king status is a modern construction that attempts to label these unique political relationships between sovereign kings and the state of Rome. The rex sociusque et amicus populi Romani or "friendly kings" held ambiguous power that was negotiated

\footnotetext{
${ }^{69}$ Polyb. 2.2, 2.5 and 2.8.

${ }^{70}$ Wilkes, Illyrians, 162 and Polyb. 2.12.
} 
with representatives of the Roman senate during the Roman Republic. ${ }^{71}$ Often these kings were expected to provide manpower and supplies for Roman endeavors. In return, Rome would aid in protecting their kingdoms. Responses to requests by client-kings were one of the factors that pulled the early empire beyond its territories, expanding its sphere of influence. Client-kings that failed to uphold their duties to the Roman Republic were annexed into the empire. During the early Principate (27 BCE-160 CE), many client-kingdoms were adsorbed and any new relationships between client-kings and Rome formed a direct tie between the Roman emperor and the king. ${ }^{72}$

In the western Balkans - conflicts with Rome initially caused by a disruption of trade networks - continued under the new guise of client-kings. These client-kings proved troublesome to Rome and frequently attempted to break ties. This happened most famously with King Demetrius of Pharos in $221 \mathrm{BCE}$ and ended with King Gentius in $168 \mathrm{BCE}$ in the Second and Third Illyrian Wars respectively. ${ }^{73}$ After these wars, many of the client-kingdoms were absorbed as possessions of Rome in the province Illyricum. A few remaining protectorates appear in the sources as they continued to ask for aid. For example, in 158 BCE Rome responded to a complaint against the Delmatae who attacked the colonies Epetion and Tragurion established on the mainland by the Greek colonists at

\footnotetext{
${ }^{71}$ Vasile Lica, The Coming of Rome in the Dacian World, trans. Carmen Patac and Mariana Neagu (Konstanz: Universitätsverlag Konstanz, 2000) 179. The phrase is found in Livy Per. 31.11.

${ }^{72}$ Mattingly, Power and Identity, 76-77.

${ }^{73}$ Wilkes, Illyrians, 163-162 and Dalmatia, 26.
} 
Issa. $^{74}$ The remaining protectorates lost their independence after the western coastal region sided with Ptolemy against Caesar during the Roman Civil War (49-45 BCE). ${ }^{75}$

The indigenous elite adsorbed from the coastal region adapted to Roman administration and retained status by continuing to organize around urban centers such as Scardona (m. Skradin, Croatia) and Lopsica (m. Sveti Juraj, Croatia) in the northwest coastal region of Liburnia (see Regional Map in Appendix D). ${ }^{76}$ At the most immediate level, urban centers allowed Rome to organize administration and tax their new territories. $^{77}$ Indigenous groups were formed into conventus (judicial assizes) which required them to travel to coastal towns for any administrative or judicial business and encouraged the association of city with government. ${ }^{78}$ The indigenous elite were promoted to direct taxation and local civic administration which was a model used repeatedly in new Roman territories. In Liburnia, the indigenous elite were elevated to administrative positions and some of these praefecti did receive Roman citizenship immediately. In the provinces, most attained citizenship through grants that elevated urban centers to municipia or after service in auxiliary military units. Citizenship usually conveyed the right to vote, exemption from some taxes, and legal rights protected by local magistrates. Most of the indigenous elite were given citizenship rights before their communities as representatives between Rome and the local population. They promoted

\footnotetext{
${ }^{74}$ Wilkes, Illyrians, 189 and Dalmatia, 30-31.

${ }^{75}$ Caes. B Civ. 3.9.

${ }^{76}$ The western Balkans had developed urban centers and trade networks with Greek colonists which Rome protected and continued to develop after these areas were added to the empire.

${ }^{77}$ Rober L. Dise, Cultural Change and Imperial Administration: The Middle Danube Provinces of the Roman Empire (New York: P. Lang, 1991) 17-18.

${ }^{78}$ Wilkes, Illyrians, 213.
} 
Roman civil law and utilized Latin which illustrated and preserved their own status in their communities. ${ }^{79}$ This familiarity with Roman administration was brought with them when they migrated to other regions of the empire including Dacia.

While Roman power over the west coast of the Balkans was the result of both negotiation and conflict, areas further east largely experienced violent conquest. The group known as the Delmatae in the western Balkans had a long history of disputes with the coastal communities. A cycle of conflict with Romans during the second century BCE influenced the construction of oppida, community strongholds, in the region as the Delmatae increased their defenses. ${ }^{80}$ By $45 / 4$ BCE, when P. Vatinius was sent to suppress the Delmatae, who had supported Pompey, he complained that instead of twenty hill forts to conquer he had over sixty. ${ }^{81}$ Augustus continued to battle tribes in the western Balkans from 35-33 BCE and after defeating the Delmatae, he established a colony of veteran soldiers at Aequum (m. Čitluk, Croatia). Unlike the urban areas in Liburnia, this center attracted few indigenous settlers and there is no record of early participation of the native elite in local governance. ${ }^{82}$ The proliferation of oppida before conquest suggests the Delmatae had previously established some form of centralized administration but did not participate (or were blocked from participation) in the Roman centers.

\footnotetext{
${ }^{79}$ Alka Starac, "The Countryside in Liburnia," in Dalmatia: Research in the Roman Province 1970-2001: Papers in Honour of J.J. Wilkes, eds. David Davison et al. (Oxford: Archaeopress, 2006) 107 and 110-111.

${ }^{80}$ Wilkes, Illyrians, 190-191.

${ }^{81}$ Cic. Fam. 5.10a.

${ }^{82}$ Wilkes, Dalmatia, 46 and 242-243.
} 
After the Pannonian War (14-8 BCE) the Romans controlled the western Balkans from Macedonia in the south to the Danube River in the north. ${ }^{83}$ Groups such as the Pannonians, Delmatae, and Pirustae were not absorbed politically as client-kings but conquered militarily which led to future unrest. During campaigns against the Germans, the Romans ordered a new auxiliary unit from Dalmatia. The gathering indigenous soldiers instead followed their leader, Bato, in rebellion against Rome in $6 \mathrm{CE}^{84}$ The Roman sources suggest the uprising was in response to heavy taxation and stress the role of strong, charismatic leaders inciting the unrest. ${ }^{85}$ But the revolt likely had a wider spectrum of causes that are not specified in these sources. The Roman historian Cassius Dio states that Bato complained to Tiberius, "You are responsible for this; for you send as guards of your flocks, not dogs or shepherds, but wolves." ${ }^{86}$ This suggests the new Roman administration was not necessarily local and that officials, such as tax collectors, were likely promoting their own interests for personal gain. The disruption in communities may have been greater than in regions where the local elite were employed.

In $9 \mathrm{CE}$ most of the tribes of the region of Illyricum were defeated. It was then split into two provinces, Pannonia and Dalmatia, and as military occupation was increased, the settlement of Roman veterans in these provinces was also used to stabilize

\footnotetext{
${ }^{83}$ Wilkes, Illyrians, 205-207.

${ }^{84}$ There were actually two men named Bato involved in the conflict. The instigator Bato was from central Dalmatia (Daesitatian) and part of the forming Roman auxiliary unit. The second Bato was from central Pannonia (Breuci). They fought together for a short time, but the Pannonian Bato betrayed his King, Pinnes, and was granted the right to rule by Rome. His time as a client-king was short as the Dalmatian Bato captured him and put him to death. Cass. Dio 55.34.4-5.

${ }^{85}$ Dise, Imperial Administration, 33 and Cass. Dio 55.29.1-2.

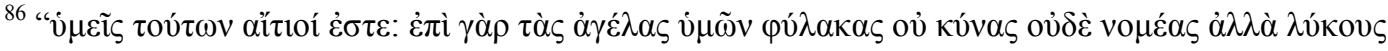
$\pi \varepsilon ́ \mu \pi \varepsilon \tau \varepsilon . "$ Cass. Dio 56.16.3.
} 
the region. ${ }^{87}$ The Roman army became a fixture on the Danube limes during the first century CE and this region became a "loyalist heartland" for emperors seeking military support by the third century and even produced several emperors. ${ }^{88}$ To achieve this, auxiliaries were taken from these provinces to serve the Roman military, which removed young indigenous men from the territory. ${ }^{89}$ Large indigenous tribes were broken apart while smaller ones were combined into administrative districts or conventus like those created on the coast. Within two or three generations, the indigenous elite began to move into the Roman cities. ${ }^{90}$ Some groups, such as the Iapodes of Dalmatia, would receive the right to use indigenous administrators, principes shortly after the revolt. ${ }^{91}$ However, it would not be until Trajan that this ius civitates peregrinae, or right of indigenous self government, would be allowed in most of the Pannonian and Dalmatian provinces. ${ }^{92}$ Within these areas were mining communities that would supply miners for Dacia.

Conquest by diplomacy and violence were common in the region that provided the majority of the miners that immigrated to other Danubian provinces. Most of the major conflicts happened almost a century before the conquest of Dacia. But accounts of continued resistance suggest conditions were not universal or ideal. Indeed, as seen in recent research on other provinces thought to be relatively peaceful, such as Gaul, the Romans were not forthcoming with details on rebellions and uprisings that often

\footnotetext{
${ }^{87}$ Wilkes, Illyrians, 207 and 212.

${ }^{88}$ Dise, Imperial Administration, 19.

${ }^{89}$ Mócsy, Pannonia and Upper Moesia, 39.

${ }^{90}$ Wilkes, Illyrians, 213.

${ }^{91}$ Wilkes, Dalmatia, 266-267.

92 Starac, "Liburnia," 112 and Mócsy, Pannonia and Upper Moesia, 134.
} 
continued up to a century after conquest. ${ }^{93}$ This may explain some of the encouraged and forced relocation of groups from troublesome regions to other areas or provinces. For example, the Roman historian Florus states that the Delmatae were forced to mine gold for the empire in Dalmatia and Ptolemy mentions the removal of the Pirustae to work at the gold mines in Dacia. ${ }^{94}$ Marginalized indigenous groups became a source of labor for extracting mineral resources for the Roman Empire.

\section{Roman Mining in the First Century CE}

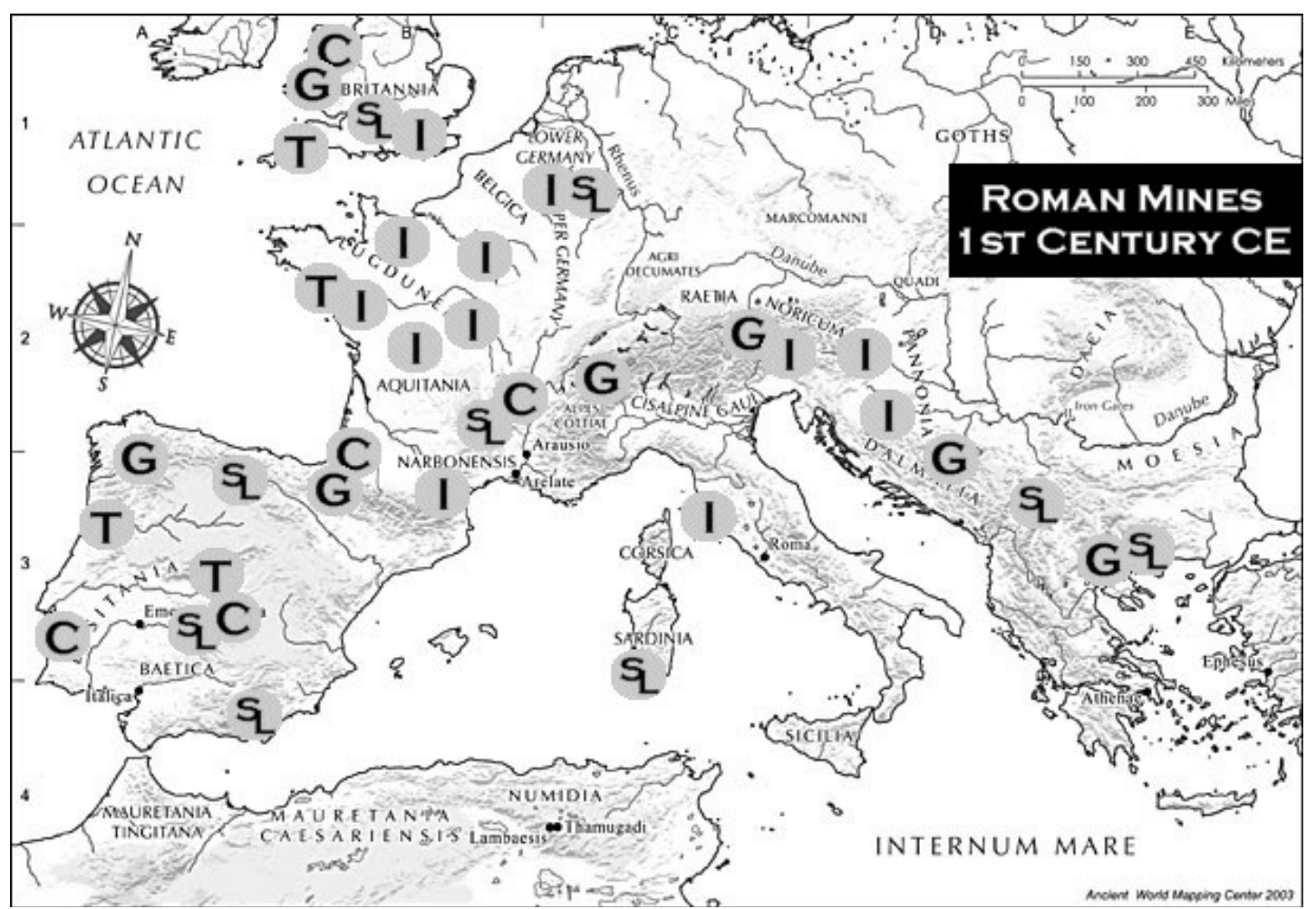

Figure 2.1: Roman Mines in the First Century CE

Approximate locations of Roman mining operations for copper (C), gold (G), iron (I), silver and lead (SL), and tin (T). Map adapted from Rome's Northern Provinces Around A.D. 100, Ancient World Mapping Center, http://www.unc.edu/awmc/awmcmap41.html.

${ }^{93}$ For example, Roman Gaul was considered conquered by 52 BCE but revolts and uprisings continued until at least 69-70 CE. Greg Woolf, Becoming Roman (Cambridge: Cambridge University Press, 1998) 30-32.

${ }^{94}$ Flor. 4.12.11-12 and Ptol. Geog. 2.16. 
"Cuneis eam ferreis adgrediuntur et isdem malleis nihilque durius putant, nisi quod inter omnia auri fames durissima est."

[She [mother earth] has to be attacked with the same iron wedges and hammers and nothing is more inflexible, except that hunger for gold which is the most inflexible of all things.]

Pliny the Elder, Naturalis Historia 33.21.72

After conquest the Romans often intensified preexisting works and provided better infrastructure to mining regions. Operations were enhanced with new technology that exploited harder rock and deeper shafts were worked from the late first century BCE through the late third century CE. ${ }^{95}$ For example, at the lead mines at Mt Kosmaj in Moesia Superior millions of tons of waste were found by archaeologists and deep shafts reached the ground water beneath the rock. ${ }^{96}$ The Romans also provided better roads that further aided the extraction of resources from these conquered regions. ${ }^{97}$ The pollution evident in ice samples from Greenland points to a spike in copper and lead production during the Roman Empire. ${ }^{98}$ This boost by the first century CE was due to an increase in supply rather than a replacement of older mines. There were some mines that were depleted by the end of this century, such as the silver and lead mines in Carthago Nova, Spain and possibly the gold mines along the Vrbas Valley in Dalmatia (see Fig. 2.1). But many gold resources were still active and the Asturian mines in northwest Spain would

\footnotetext{
95 Jean Andreau, “Recherches récentes sur les mines romaines, II,” Revue Numismatique 32 (1990): 98.

${ }^{96}$ Mócsy, Pannonia and Upper Moesia, 133.

${ }^{97}$ This increased trade in the Danube region in general. But not all roads were finished until the mid second century $\mathrm{CE}$ and even the river routes were not completely established until the end of the first century. Mócsy, Pannonia and Upper Moesia, 88 and 122-123 and Wilkes, Illyrians, 212.

${ }^{98}$ Metalwork in the Chinese, Indian and Parthian/Persian empires also contributed to this spike in pollution. Mattingly, Power and Identity, 169 ftnt 4.
} 
be profitable for another 100 years. ${ }^{99}$ Complaints of the failure of mines and the use of laws to keep mining laborers on location are not evident until the turn of the fifth century. $^{100}$

The accelerated mining activities influenced the amount of labor required. During the Roman Republic, mines were the property of the Roman people and could be leased to individuals or municipalities who then used an assortment of hired, unpaid, and enslaved labor. ${ }^{101}$ The free labor of miners appears as a later development and the term for a miner, cuniculator, does not appear as a profession until Augustus. ${ }^{102}$ During the early Principate mining territories were state owned and the provincial representatives leased the mines but still relied heavily on slave labor. ${ }^{103}$ Additionally, the elite in areas that experienced violent conquest, such as northwest Spain, could be required to ensure a specific level of production as their munera, or required duties, which encouraged unfree labor and relocation of workers. ${ }^{104}$ By the first century, the movement and establishment of miners as whole communities were supported by imperial administrators.

\footnotetext{
${ }^{99}$ Almudena Orejas and F. Javier Sánchez-Palencia, "Mines, Territorial Organization, and Social Structure in Roman Iberia: Carthago Noua and the Peninsular Northwest," American Journal of Archaeology 106, no. 4 (2002): 586-587 and 589.

${ }^{100}$ Specifically Cod. Theod.10.19.3 and 5. Oliver Davies, Roman Mines in Europe (New York: Arno Press, 1979) 2 .

${ }^{101}$ Historian Oliver Davies suggests that even piecemeal corvée or unfree labor could be requisitioned from rural farmers as the need required. And further comments that the Romans were "scarcely capitalists." Davies, Roman Mines, 11.

${ }^{102}$ Before Augustus only barbarians and Italians were noted doing mining work and not Roman citizens. Interestingly the terms for mine, fodina and metallum can also be traced to Hispano Iberian terms, fossor

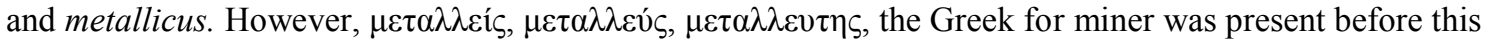
time. John F. Healy, Mining and Metallurgy in the Greek and Roman World (London: Thames and Hudson, 1978) 133.

${ }^{103}$ F.H. Thompson, The Archaeology of Greek and Roman Slavery (London: Duckworth, 2003) 156.

${ }^{104}$ Mattingly, Power and Identity, 172.
} 
The combined effect of entrepreneurial opportunity and the state involvement in moving communities to exploit mines was a trend seen in the Danube provinces before the conquest of Dacia. During the first century there is evidence the empire used force to establish labor at the mines in Dalmatia and Moesia Superior as they had in Spain. When miners were needed, distance was not an issue and evidence at modern Wiesenau, Germany suggests miners from Dalmatia may have been moved to Noricum to work the mines (as they would be for Dacia later). ${ }^{105}$ As stated above, Florus writes that after the provincial revolt of 6-9 CE, Augustus appointed C. Vibius Postumus who oversaw transfer of the Delmatae to the gold mines. ${ }^{106}$ Other groups who were relocated to work in the mines included the Pirustae in Dalmatia and the Dardani in Moesia Superior. ${ }^{107}$ The treatment and mobility of these miners varied. At Domavia (near m. Srebrenica, Bosnia-Herzegovnia), elaborate baths were built before the end of the first century for the mining district, especially for the silver miners - an investment for their health which suggests they were not invaluable or disposable labor. ${ }^{108}$ Nonetheless, at the same location, a block of 120 homes has been interpreted as both slave housing or a restricted community, possibly under military surveillance. ${ }^{109}$ Perhaps it was a community strategy for living in the harsh mountainous environment. But the numisitic evidence also paints Domavia as an isolated settlement where most of the coins in circulation were locally

\footnotetext{
${ }^{105}$ Thompson, Greek and Roman Slavery, 180.

${ }^{106}$ Florus also criticizes the barbarians for mining with such zeal one would think they were keeping all the profits which suggests this was anything but the Roman expectation. Flor. 2.25.12

${ }^{107}$ The movement of the Dardani may have been as late as Trajan. Dise, Imperial Administration, 63.

${ }^{108}$ More about the health of miners and the efforts to counter their work hazards will be discussed in Chapter 4. Wilkes, Dalmatia, 381-382.

${ }^{109}$ Thompson, Greek and Roman Slavery, 180.
} 
made suggesting that the conductores or overseers controlled the distribution of goods. ${ }^{110}$ In other areas of the Danube provinces, small coins, quadratnes and semisses, once thought to be unique to mining regions have a larger distribution suggesting that trade at all mines was not limited within one community. ${ }^{111}$ It appears the Romans were more interested in getting labor to the mines which included forced labor but likely held opportunities for contracted laborers as well.

The Roman Empire needed resources and extracting them expediently and efficiently influenced the focus on infrastructure and labor. New water-lifting technology allowed for deeper exploration and a combination of forced indigenous workers, slaves, and free laborers supplied the increasing demand. Although a few mines were producing less in the first century CE, most were at their peak or slowly building rather than declining. The conquest of Dacia, like that of the provinces above, was a multifaceted process with numerous causes. Nonetheless, extra money for the Danube army and the emperor's treasury was not an opportunity that would be wasted by an expanding empire.

\section{The Conquest of Dacia}

In the archaeological record, evidence of a related material culture labeled as Geto-Daci, Dacian, and sometimes northern Thracian, ranged from the eastern Carpathian Basin to the Black Sea coast, mostly north, but also found south, of the Danube River. ${ }^{112}$ The kingdoms of Dacia that challenged Rome were primarily focused

\footnotetext{
${ }^{110}$ Davies, Roman Mines, 13-14.

${ }^{111}$ These coins were $1 / 4$ as (quadrantes) and $1 / 2$ as (semisses). Alfred Michael Hirt, Imperial Mines and Quarries in the Roman World: Organizational Aspects, 27 BC - AD 235 (Oxford: Oxford University Press, 2010) 65.

${ }^{112}$ As noted in the introduction, labeling cultures is problematic. These labels are the most common in discussions of the region during the Late Iron Age but do present a precise or static picture. For example, in a first century BCE cemetery at Orlea in southern Romania near the Danube River, the pottery suggests a
} 
around the Transylvanian Plateau of modern Romania. The alluvial plains surrounded by the Carpathian Mountains create a "natural fortress" that protects fertile land and abundant natural resources. ${ }^{113}$ Before Roman occupation, wheat, rye, millet, barley and lentils were harvested and Strabo states that wine was also cultivated. ${ }^{114}$ The majority of Late Iron Age Dacian settlements were rural with nuclear family units and larger communities developed around "citadel" structures. In the larger citadels, religious structures and industry were protected inside and the bulk of settlement remained outside. $^{115}$ One of these larger citadels, excavated at Grădiştea Muncelului, is identified as the center of the Dacian kingdom, Sarmizegetusa Regia. ${ }^{116}$

Sarmizegetusa Regia, a citadel high in the Orăştia Mountains, and the surrounding regions provide evidence that the Dacian kingdom controlled the majority of metallurgy and mining. ${ }^{117}$ In the Apuseni Mountains north of the citadel, evidence of Dacian forts

Geto-Daci cemetery but evidence of sacrifices show a "Celtic" influence or difference in practice from other Geto-Daci settlements in the region. E. Comşa, "Contributionà l'étude des rituels funéraires des Iie-Ie siècles av.n.è. Dans le sud-est de l'Oltenie (Les sépultures d'Orlea)," in Apulum X: Arheologie-IstorieEtnografie in Memoriam Avram Iancu: 1872 - 1972 (Alba Iulia: Muzeul de Istorie, 1972) 78.

${ }^{113}$ I.P Haynes and W.S. Hanson, "An Introduction to Roman Dacia," in Roman Dacia: The making of a Provincial Society, eds. W.S. Hanson and Ian Haynes (Portsmouth: Journal of Roman Archaeology, 2004) 12.

${ }^{114}$ Haynes and Hanson, "Roman Dacia," 14 and Strabo 7.3.11.

${ }^{115}$ K. Lockyear, "The Late Iron Age Background to Roman Dacia," in Roman Dacia: The making of a Provincial Society, eds. W.S. Hanson and Ian Haynes (Portsmouth: Journal of Roman Archaeology, 2004) 36-37.

${ }^{116}$ Although undoubtedly a major center for the Dacian kingdom, the only direct evidence of the leader Decebalus possibly ruling from Grădiştea Munceluiui is a vessel with DECEBALVS PER SCORILO inscribed four times on the lip. Lockyear, "Late Iron Age," 44. Ioana Oltean argues the massive religious structures at Grădiştea Munceluiui point to more religious significance than political. However, these are not necessarily exclusive. I.A. Oltean, "Dacian Ethnic Identity and the Roman Army," in The Army and Frontiers of Rome: Papers Offered to David J. Breeze on the Occasion of his Sixty-Fifth Birthday and his Retirement from Historic Scotland, eds. W.S. Hanson, Lindsay Allason-Jones, and David John Breeze (Portsmouth: Journal of Roman Archaeology, 2009) 91.

117 These mountains are in the southern section of the Carpathians in this region. 
surrounding the mining region (a pattern later adopted by the Romans) also suggests elite control over mineral resources. ${ }^{118}$ The evidence of gold mining but a lack of gold items in elite burials in the Carpathian Mountains may suggest that the Dacian royalty held a monopoly over precious metals. Indeed, the preference for silver jewelry in Dacian elite burials may be a further indication of the limited access to gold. ${ }^{119}$ Similar elite control appears in evidence for the extraction of iron ores and metallurgy. Professional craftsmen were focused at Sarmizegetusa Regia where manufacture outnumbered agricultural production. ${ }^{120}$ The large amount of storage and intensity of production coincides with the placement of these workshops in the immediate vicinity of the temples which may indicate a tie to religion. ${ }^{121}$ Once Sarmizegetusa Regia was conquered by the Romans in the First Dacian War (101-102 CE), the religious structures were destroyed, the population forcibly moved, and mining activity was not resumed in this region as in other areas of the province, despite the rich iron ores. ${ }^{122}$ It is likely the region was too

\footnotetext{
${ }^{118}$ Diaconescu, "Towns of Roman Dacia," 123.

${ }^{119}$ Oltean, Dacia, 106. Gold may have had reserved for religious rights. Although after conquest, a dedication to the Nymphs by Decebalus Luci, a Dacian, on a gold tablet may suggest some continued association between the precious metal and religious activity. The tablet is $16.2 \times 6.9 \mathrm{~cm}$ and reads "Nymfis(!) Decebalus Luci posuit / Decebalus, son of Lucus dedicated to the Nymphs" AE (1992) 1483.

${ }^{120}$ Oltean, Dacia, 74, 104 and 115.

${ }^{121}$ Oltean, Dacia, 110. This matches the Greek and Roman perception of Dacian religion. In the Geography, Strabo identifies the holy mountain Kogaionon (Kwyoiovov) with the Dacian priest Zamolxis who became the first of priestly counselors to the Dacian kings. It is plausible this legendary priest co-ruler provided a partial explanation for the foundation of a strong Dacian state for the Greeks and Romans. While most barbarian states where viewed as susceptible to excess and disorganization this was not the stereotype for Dacia. In the same passage, Strabo states that Zamolxis was first a slave to Pathagoras and then studied further in Egypt before returning to the Getae. Through his guidance, a religion based on restraint was established. In a later passage, Decaeneus, mirroring the earlier Zamolxis, aids Burebista in uniting the Getae through religious doctrine that encouraged discipline, sobriety and obedience - this created a formidable enemy on the field. Strabo 7.3.5 and 7.3.11. Archaeologists now think this mountain was in the Orăştia Mountains, near the citadels like Sarmizegetusa Regia. Oltean, Dacia, 48.

${ }^{122}$ Oltean, "Dacian Ethnic Identity," 91.
} 
symbolic of the Dacian kingdom both politically and religiously and, after a series of wars, Rome had little interest in keeping the region populated.

This centralized Dacian state, like other Late Iron Age societies, participated in considerable trade in both goods and ideas before the conquest by Rome. Although intensity of trade varied, Roman, Italic, and Hellenistic coins appear in the region by the fourth century BCE. ${ }^{123}$ By the time of Roman conquest, the Dacians were minting counterfeit Roman denarii at Sarmizegetusa Regia. In addition to coin styles, Roman lead and stone single-plated scale weights were also found at the citadel, likely used for trade. ${ }^{124}$ Many of the elite fortifications and larger citadels, like Sarmizegetusa Regia, also show the hybridization of Dacian and Greek building technology, labeled by archaeologists as murus dacius. These unmortared stone walls with a rubble core included Greek letters inscribed on various blocks, possibly suggesting placement or order. ${ }^{125}$ Exchanges also included merchants and craftsmen who traveled from other areas of the Roman Empire to Late Iron Age Dacia. ${ }^{126}$ During the end of the first century $\mathrm{CE}$, if not earlier, runaways and deserters from the Roman Empire found refuge in

\footnotetext{
${ }^{123}$ Davies, Roman Mines, 204.

${ }^{124}$ Oltean, Dacia, 91 and 112.

${ }^{125}$ Lockyear, "Late Iron Age," 36. However, the Dacians continued to use timber to hold the blocks contrary to the Greek practice of using iron. Ioan Glodariu, Dacian Trade with the Hellenistic and Roman World, trans. Nubar Hampartumian (Oxford: BAR International Series, 1976) 91.

${ }^{126}$ Oltean, Dacia, 52. Change of products and coins suggest trade shifted predominantly west with the Italian traders holding a bigger market than the Greek traders by the first century BCE. Glodariu, Dacian Trade, 72. These exchanges appear in the ancient sources as experts in crafts of peace and war traveled to Dacia as arranged in a peace settlement between the Dacian king Decebalus and Domitian in 89 CE. Cass. Dio 67.7.4.
} 
Dacian territory. ${ }^{127}$ The region and resources of Dacia were known to Roman merchants before conquest which likely aided the swift development of the region under Roman rule.

Although the real extent of their kingdoms is uncertain, the Romans discuss two kings who had unified the region and were viable opponents, Burebista (ca. 82-44 BCE) and Decebalus (d. $106 \mathrm{CE}$ ). King Burebista controlled a vast area that stretched to the Black Sea and threatened areas south of the Danube. During Caesar's Civil War (49-45 BCE), an inscription found at Dionysopolis (m. Balchik, Bulgaria) from ca.48 BCE suggests Burebista negotiated an alliance with Pompey. ${ }^{128}$ After the death of Burebista, the unity fell apart and a series of smaller kingdoms remained that appear both in the Roman literature and in the archaeological record by the coins they produced. ${ }^{129}$ The central citadel, Sarmizegetusa Regia, which was founded under King Burebista's rule, continued as an elite center which is evident in a partial dynastic list compiled from coins and Roman and Greek sources. ${ }^{130}$ These smaller kingdoms continued to attack Roman allies and territories south of the Danube.

Dacia was perceived by the Romans as a unified and organized threat to the Roman territories along the Danube limes. Unlike the inconsistent alliances of groups in the recently conquered provinces of Dalmatia, Pannonia, and Moesia Superior, Dacia

\footnotetext{
${ }^{127}$ Most famously was Dio Chrysostom who went in exile with Getae north of the Danube whom he described as intelligent but uninterested in leisure and impatient for action (like pawing horses). Dio Chrys. Or. 12.16-19.

${ }^{128}$ Oltean, Dacia, 47 and IGBulg $I^{2}$ 13: 32-37.

${ }^{129}$ Radu Florescu, The Art of Dacian-Roman Antiquity (Bucharest: Meridiane Publishing House, 1986) 59 and Lica, Dacian World, 100.

${ }^{130}$ Oltean, Dacia, $48-49$.
} 
appears in Roman accounts as united under strong kings, even after the death of

Burebista. The Dacians could be powerful allies and Suetonius states that Augustus at one time considered marrying his sister to the Dacian King Cotiso. ${ }^{131}$ There is some question as to the veracity of this proposal. However, the inclusion of it in Suetonius's biography must have retained some plausibility for his elite Roman audience. Strabo, a contemporary of Augustus, described the Dacian kingdoms after Burebista as humbled but still capable of fielding an army of $40,000 \cdot{ }^{132}$ Thus, even a military alliance was a possible motivation for establishing some relationship with the Dacian kings. Cotiso may have been an amicus et socius to Rome or Augustus, an ally that did not require submission as a client. ${ }^{133}$ Despite this possible alliance, the skirmishes between Rome and Dacia continued. Augustus later claimed to succeed against the Dacian threat when he restricted these groups to the north side of the Danube and ensured the return of Roman captives. ${ }^{134}$ Florus notes that the Dacians were not subdued at this time, "but had been repelled and scattered." ${ }^{, 135}$

Later conflicts increased the perceived threat of a strong Dacian state. During another Roman civil war, "The Year of the Four Emperors" (69 CE), the historian Tacitus

\footnotetext{
${ }^{131}$ Suet. Aug. 61. It is interesting to note that Suetonius, a Roman biographer, identifies King Cotiso with the Getae. As discussed in Chapter 1, the difference between Getae and Daci can be ambiguous and the Getae were sometimes associated with groups south of the Danube. However, Florus also mentions Cotiso and makes it clear his kingdom was north of the Danube from which he raided south in the winter over the frozen Danube. Flor. 2.28.

${ }^{132}$ Strabo 7.3 .12

${ }^{133}$ In his examination of the judicial relationship between Dacia and Rome, Lica suggests that Rome could often impose the terms of deditio on neighboring client kingdoms but Dacia was too powerful to force into this unequal partnership. He defines the creation of deditio as the "unconditional surrender contained in itself both the dissolution of the other party and, at the same time, its reconstruction, now subject to Rome, with a legal status determined at Rome's discretion." Lica, Dacian World, 175 and 117-118.

${ }^{134}$ Res Gestae 30.

135 "Sic tum Dacia non victa, sed summota atque dilata est." Flor. 2.28.
} 
states that there was a real concern that the Dacians, who attacked the Danube limes (yet again), would work with Germanic groups to invade northern Italy. ${ }^{136}$ Reinforcements prevented this Dacian invasion but not long after, Decebalus again unified the western territories and conflict with Rome under Domitian (r. 81-96 CE) escalated. In 85/6 CE the Governor of Moesia, Oppius Sabinus, and his legion were defeated by the Dacians and the avenging army sent by Domitian under the prefect Cornelius Fuscus was also defeated. ${ }^{137}$ Two years later, Tettius Julianus gained a victory against the Dacians at Tapae. ${ }^{138}$ But Domitian suffered a defeat against the Marcomanni in the same year and by $89 \mathrm{CE}$, the Roman Emperor negotiated a peace settlement with Decebalus. Cassius Dio, who was a harsh critic of Domitian and accentuated his faults with examples of the emperor's depravity, writes that the peace treaty with Decebalus was not favorable to Rome and when the emperor celebrated his triumph, it lacked war trophies and was more comparable to a funeral. ${ }^{139}$ As part of the peace agreement Domitian paid money to the Dacians and supplied them with "all sorts" of skilled craftsmen related to both "peace and war." ${ }^{\text {A40 }}$ Although Cassius Dio paints this as a fault of Domitian, providing such "subsidies" could be done with established client-kingdoms and was practiced by other

\footnotetext{
${ }^{136}$ Tac. Hist. 3.46.

137 The date estimates are from Mócsy who also notes that the legion lost by Oppius Sabinus was likely the V Alaudae. Mócsy, Pannonia and Upper Moesia, 82, Suet. Dom. 6 and Eutr. 7.23.

${ }^{138}$ Cass. Dio 67.10 .

${ }^{139}$ Cass. Dio 67.6.3. Cassius Dio's bias is evident in many passages - while Domitian's ill fated armies waged war with Dacia, the emperor remained in Moesia and feasted. The lackluster triumph is substantiated by Suetonius who, unlike Cassius Dio, was a contemporary to Dacian conquest and does not comment on the righteousness of Domitian's actions. Another heavily biased account by the Christian author Orosius also notes that Domitian's triumphs celebrated the destruction of his legions. Cass. Dio 67.9.6; Suet. Dom. 6; Oros. 7.10.

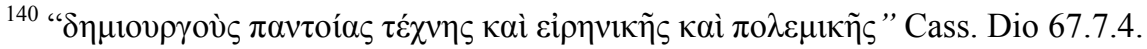


emperors as well. ${ }^{141}$ The fact that Domitian crowned Decebalus's representative suggests that although the Dacians gained some immediate benefits, their status with Rome had changed. ${ }^{142}$ This unequal relationship was one of the factors that influenced the deteriorating relationship between the two and encouraged the eventual conquest of Dacia.

For the Romans, Decebalus proved to be untrustworthy and conflict led to conquest and the creation of a new province. Many reasons for the conquest of Dacia have been proposed, including: a war created to solidify the newly appointed Emperor Trajan's power among his legions, a Roman concern for establishing frontier security, a war of honor after Domitian's disgraceful peace agreement, or a grab for rich timber and mineral resources. ${ }^{143}$ According to Cassius Dio, Trajan's First Dacian War began in 101 $\mathrm{CE}$ due to a concern that the kingdom was regaining too much power and confidence while still receiving money from Rome. ${ }^{144}$ At this point Trajan did not have intentions to conquer the region but only aimed to check the growth of Rome's client. The coins that celebrated the Roman victory over Dacia, stamped with Dacia Victa, included the image

\footnotetext{
${ }^{141}$ Lica points to Trajan who gave subsidies to the Roxolani which were later increased by Hadrian as seen in the SHA Hadr. 6.8. Lica, Dacian World, 189.

${ }^{142}$ Cassius Dio suggests that Domitian crowned Decebalus's representative Diegis in error or without merit. It seems unlikely that this gross of an error would be made, especially when Dio Cassius also states Decebalus submitted a letter to Rome (of course forged by Domitian), rather than Diegis. Cass. Dio 67.7.3. The crowning of defeated kings was not unknown. For example, Tiridates of the Armenians traveled to Rome to receive his crown after his defeat by Nero. Tac. Ann. 15.

${ }^{143}$ B. Rankov, "A 'Secret of Empire' (imperii arcanum): An Unacknowledged Factor in Roman Imperial Expansion," in The Army and Frontiers of Rome: Papers Offered to David J. Breeze on the Occasion of his Sixty-Fifth Birthday and his Retirement from Historic Scotland, eds. W.S. Hanson, Lindsay Allason-Jones, and David John Breeze (Portsmouth: Journal of Roman Archaeology, 2009) 168, Haynes and Hanson, "Roman Dacia," 15, and S. Baron et al., "Lead isotope analyses of gold-silver ores from Roşia Montană (Romania): A first step of metal provenance study of Roman mining activity in Alburnus Maior (Roman Dacia)," Journal of Archaeological Science 38 (2011): 1093.

${ }^{144}$ Cass. Dio 68.6.1.
} 
of Mars the Avenger (Mars Ultor). This symbolism possibly points to revenge for the earlier losses under Domitian and/or disciplinary action against a client-kingdom proving disobedient to Rome. ${ }^{145}$ At the end of the First Dacian War, Decebalus agreed to "hand over his weapons, machines and engine-makers, give up deserters, take down walls and withdraw from conquered territories, and besides consider their [Rome's] enemies the same as their own."146 The conditions cited by Cassius Dio suggest that the Dacians lost their privileges granted by Domitian because, as a client-kingdom, they were acting against Roman interests. Decebalus also agreed to return deserters and soldiers from the Roman Empire who added to his military prowess. ${ }^{147}$ The Second Dacian War began in 105 CE after Decebalus began to rebuild his forts and military and strike against those who had aided the Romans in the first war. ${ }^{148}$ A letter from Pliny the Younger to Trajan also mentions contacts with Roman enemies as he relates that a Callidromus, arrested by two employers, confessed he had recently escaped from Parthia, an enemy of Rome, where he had been sent by Decebalus to the Parthian king. ${ }^{149}$ The second war was one of total conquest and before Decebalus was dead, D. Terentius Scaurianus was appointed to the governorship of the new province of Dacia. ${ }^{150}$ The coins after this war mark the

\footnotetext{
${ }^{145}$ Bennett, Trajan, 87 and 95.

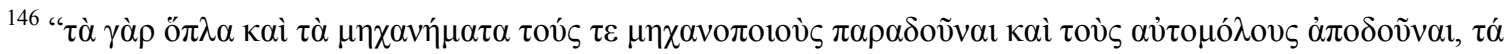

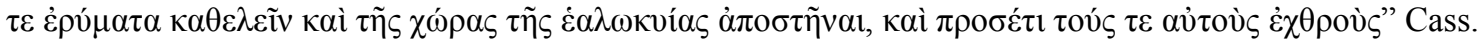
Dio 68.9.5.

${ }^{147}$ Cass. Dio 68.9.6.

148 This justification is common in Roman rhetoric about the cause of war and may be in part accentuated by Cassius Dio who wrote after the events and made a clearer cause for action than may have existed. Cass. Dio 68.10.3.

${ }^{149}$ Plin. Ep. 10.74.

${ }^{150}$ This was directly after Decebalus had lost strongholds like Sarmizegetusa Regia and was trying to regroup. He would commit suicide shortly after. Bennett, Trajan, 101 and 163.
} 
capture of Dacia (Dac(ia) Cap(ta)) rather than a victory or vengeance and in Rome the conquest was celebrated during 123 days of spectacles including 10,000 gladiators fighting in the arena and 11,000 animal sacrifices. ${ }^{151}$ Trajan's Forum included over eighty-two statues of defeated Dacians and the famous column which commemorated the two wars. ${ }^{152}$ The fate of the Dacians is still debated today and, unlike other provinces where the local elites were used to establish Roman civitates governments, the local elite hierarchy was eliminated from immediate power and inhabitants from around the empire were encouraged to colonize and demonstrate Roman government.

\section{The Colonization of Dacia}

"Dacia enim diuturno bello Decibali viris fuerat exhausta." [In fact, Dacia had been exhausted of men by the long war of Decebalus.] Eutropius, Breviarium ab urbe condita, 8.6

Due mostly to this fourth century passage from Eutropius, which describes the reason for the mass colonization of Dacia under Trajan, the imperial conquest of Dacia has been historically viewed as especially violent in which the kingdom was "exhausted of men" because of the number of Dacians killed or deported as slaves in the two wars. ${ }^{153}$ The tumultuous relationship between Rome and Dacia was often used as a raison d'être for the severe reprisals and sometimes deemed annihilation of the Dacians. ${ }^{154}$

\footnotetext{
${ }^{151}$ Bennett, Trajan, 102 and Cass. Dio 68.15.1.

${ }^{152}$ Wheeler, "Dacian Wars," 1205.

${ }^{153}$ Ioannes (John) Lydus states 500,000 Dacians were enslaved in his sixth century account. Lydus Mag. 2.28 .

${ }^{154}$ Ruscu gives a detailed review of this problem in his article. He notes that as recently as 2000 this has been debated by C.C. Petolescu and M. Babeș. The interpretation of similar passages from Julian's Caesares where he states the Dacians were conquered/annihilated depends on the translation. Ruscu, "Extermination of the Dacians," 75-76.
} 
Evidence within the province of Dacia paints a more complex picture to the outcome of conquest. ${ }^{155}$ Some Dacians retreated outside the province after conquest and were known as "free Dacians" who lived beyond the reach of the governor. However, the exchange of goods and later refuge offered to them during the Marcomannic Wars (ca.167/8-180 CE) may suggest they were not completely untouched by changes in the Roman province. ${ }^{156}$ The abandonment of some Late Iron Age sites, like Sarmizegetusa Regia, substantiates the forced removal of some Dacians. As noted above, the destruction of this site may have had more to do with its political and religious significance to the Dacian kingdom. ${ }^{157}$ Recent archaeology illustrates repeatedly that Dacians continued to inhabit the region. Rural sites, such as Obreja, Uioara de Jos, and Slimnic Şarba-Stempen, have shown post conquest continuity with varying levels of acquired Roman material goods and technology. ${ }^{158}$ A recent reinterpretation of rural

\footnotetext{
${ }^{155}$ Evidence of Dacians conscripted into the Roman military suggests that not all Dacians were forced into slavery. These soldiers maintained a Dacian identity and like other conquered groups were encouraged to retain their military specialization and equipment. Hadrian had "barbarian" units continue to practice their unique skills. Arr. Tact. 44.1. The equipment of Dacian soldiers, namely the Dacian sword known as a flax, is seen on altars and building inscriptions in Britain. These soldiers had more reason to identify their Dacian identity away from the province and interestingly, a century after conquest a Dacian soldier might still name his son Decibalus(!). D.B. Saddington, "Recruitment Patterns and Ethnic Identities in Roman Auxiliary Regiments," in The Army and Frontiers of Rome: Papers Offered to David J. Breeze on the Occasion of his Sixty-Fifth Birthday and his Retirement from Historic Scotland, eds. W.S. Hanson, Lindsay Allason-Jones, and David John Breeze (Portsmouth: Journal of Roman Archaeology, 2009) 88.

${ }^{156}$ These Dacians were not cut off from Rome and in $180 \mathrm{CE}$ were granted admittance into the province during the Marcomannic Wars. Mócsy, Pannonia and Upper Moesia, 187.

${ }^{157}$ Oltean, Dacia, 217.

${ }^{158}$ Additional sites include Cristeşti, Cicau-Saliste, Hunedoara/Sempetru Hill, Şura Mică and possibly Noslac. Roman pottery, kilns, and bread ovens are the most frequent examples of Roman goods and technology. Oltean argues the use of Roman materials and technology had more to do with availability than ethnicity. Adrian Husar and Nicoleta Man, "The Roman Rural Settlement of Cristeşti," in La vie rurale dans les provinces romaines: vici et villae: actes du IIIe Colloque roumano-suisse, Tulcea, 8-15 octobre 1995 à l'Institut de recherches eco-muséales de Tulcea, ed. Victor Henrich Baumann (Tulcea, Roumanie: Institutul de cercetări eco muzeale, 1998) 58-60, Dumitru Protase, "Un village Daco-Romain des Iie-Ive siecles a Obreja en Transylvanie," in La vie rurale dans les provinces romaines: vici et villae: actes du IIIe Colloque roumano-suisse, Tulcea, 8-15 octobre 1995 à l'Institut de recherches eco-muséales
} 
villas suggests that some of these sites may have belonged to elite Dacians instead of colonists. The mixture of goods and architecture at villa sites like Vintu de Jos, preconquest coin hoards at villas Teius and Decea as well as the pre-conquest preference for settlement outside citadel centers may suggest the Dacian elite remained in rural areas where they were able to retain some status. ${ }^{159}$ Indeed, Cassius Dio mentions that many Dacians transferred their allegiance to Trajan before the completion of the second war - it is doubtful they would necessarily be completely disregarded when Rome had historically shown a preference for loyal elite local leadership. ${ }^{160}$ Nonetheless, the rural areas were not untouched and there was a dramatic increase in the number of rural settlements from $140 / 50$ before conquest to 270 under Roman colonization which clearly indicates the immigration of colonists did have an impact on the local landscape. ${ }^{161}$ In the urban centers the evidence of colonization is more direct and many were founded on sites that do not show evidence of pre-conquest inhabitancy. Even places named after Dacian centers, like Ulpia Traiana Sarmizegetusa and Apulum (m. Alba Iulia), were new Roman foundations established at a distance from their pre-conquest counterparts. ${ }^{162}$ In the growing urban communities the Dacian elite are represented in

de Tulcea, ed. Victor Henrich Baumann (Tulcea, Roumanie: Institutul de cercetări eco muzeale, 1998) 83 and 86, Oltean, Dacia, 147 and 201 and Lockyear, "Late Iron Age," 37.

${ }^{159}$ Oltean, Dacia, 206 and Ioana Oltean and W.S. Hanson, "Villa Settlements in Roman Transylvania," Journal of Roman Archaeology 20 (2007): 115.

${ }^{160}$ Cass. Dio 68.11.1.

${ }^{161}$ Oltean, Dacia, 211.

${ }^{162}$ Ulpia Traiana Sarmizegetusa was established $42 \mathrm{~km}$ away from Sarmizegetusa Regia and the new Apulum was $20 \mathrm{~km}$ from the native center. Oltean, Dacia, 210. 
only $2-3 \%$ of the found epigraphic evidence. ${ }^{163}$ To a limited degree, this may suggest a preference by the native elite. More likely, this lack of involvement in urban public life illustrates that Dacia's provincial government, economy, and culture was heavily influenced by immigrants instead. While the region was not "exhausted" of all Dacians, they definitely had become the minority.

The colonists were central to the changes in the region and the development of the new province. Onomastic data from the urban centers provides evidence of immigrants from Italy, Noricum, Pannonia, Dalmatia, Moesia Superior and other areas of the Greek East with this last group making up 1/5 of the urban populations of Ulpia Traiana Sarmizegetusa and Apulum alone. ${ }^{164}$ Indeed, the influx of settlers was greater than other areas of the western Roman Empire as both veterans and entrepreneurs were enticed by an area rich in resources. ${ }^{165}$ Most colonists with Roman citizenship settled in the new urban centers. Peregrini or foreign residents in the empire also immigrated but, as in the case of those with Illyrian names, were more focused in rural occupations, such as mining. ${ }^{166}$ The colonists' perception of what was Roman undoubtedly varied and appears in the material record. There is continued disagreement by historians and archaeologists concerning the level of Romanization in the population; some view the differences

\footnotetext{
${ }^{163}$ Oltean places this number at 2\% but Ruscu has the figure above 3\%. Oltean, "Rural Settlement," 152 and Ruscu, "Extermination of the Dacians," 78.

${ }^{164}$ Haynes and Hanson, "Roman Dacia," 21.

${ }^{165}$ Oltean notes the influx into towns in Dacia was spurred by the higher number of veterans and immigrants. Oltean, Dacia, 174-175.

${ }^{166}$ For example, in Vargas study of peregrine names, Illyrian names are the third most attested behind Italic and Greek names. When the rural mines of Alburnus Maior are added, they then jump to first place. Varga, "The Peregrine Names from Dacia," 239 and 242. Sotropa's review of inscriptions at Apulum have also shown that 3/4 had Roman tria nomina while 1/4 were peregrine. Valeriu Sotropa, Le droit Romain en Dacie (Amsterdam : JC Gieben, 1990) 158.
} 
between colonists illustrate that they were still becoming Roman while others argue they were already well attuned to Roman civic life and public expectations. ${ }^{167}$ Romanization again proves an inadequate concept to examine the complexities in provincial society as quantifying their success in Roman acculturation can be subject to the scholars own interpretations of what is Roman.

Every effort was made to increase resources already extracted from the region. In addition to harvesting timber and mining iron, copper, silver and salt, Dacian gold drew the most attention from the ancient authors and it is estimated that 1.3 tons were extracted from the province in less than 170 years. ${ }^{168}$ Earlier historians, such as Oliver Davies, who is cited often for his comprehensive research in his Roman Mines in Europe, estimated that there was a lag between conquest and the development of mining activities. ${ }^{169}$ Recent research has shown that there was continuity at many sites as well as the increased development of new sources by both Dacians and colonists. Pre-Roman mining activity is now recognized near Alburnus Maior and the continuation of surface exploitation of gold from sand is noted at Pianu de Sus. The site of Uioara de Jos, mentioned above for its evidence of continued Dacian habitation, also maintained salt mining activity. Although these are only a few concrete examples, the relatively fast

${ }^{167}$ Oltean, Dacia, 204 and Haynes and Hanson, "Roman Dacia," 21.

${ }^{168}$ Mining is believed to have started shortly after conquest. Dacia was a Roman province 106-271/5 CE (ca.170 years). The mines were not active the entire time as there was a break during the Marcomannic Wars (ca.167/8-180 CE) and although the mines were reopened, the exact date is uncertain. Hanson and Haynes believe the estimate of 1.3 tons is too low and more gold than this was extracted over the span of Roman occupation. Haynes and Hanson, "Roman Dacia," 13.

${ }^{169}$ Davies is still cited often for his comprehensive review of mines throughout the Roman Empire although the text was originally published in 1935. The trapezoidal tunnels at Alburnus Maior Davies recognized as distinct from Roman works but attributed them to later medieval miners. Carbon dating of items found in these tunnels has since dated them to pre-Roman conquest and continued into Roman occupation which suggests there was only a short break (if any) between conquest and mining activity (more on this in Chapter 4). Davies, Roman Mines, 205 and 200. 
development of mining illustrates that the exploitation of rich sites continued shortly after conquest. $^{170}$

The Roman colonists wasted little time organizing administration and establishing urban centers where the extraction of resources could be easily accomplished. ${ }^{171}$ The organization of the province officially started in 106 CE. ${ }^{172}$ The veteran Colonia Ulpia Traiana Sarmizegetusa was founded in a location that provided close access to the exploitation of the western Apuseni and Poinana Ruscă Mountains as well as direct control of the salt route that connected trade from Pannonia to Upper Moesia (see Regional Map in Appendix D). This colony was a magnet for new immigrants and the seat for the governor who managed taxation and the judicial system. ${ }^{173}$ Apulum (m. Alba Iulia) served as the base for legio XIII Gemina and was also well situated near the Apuseni Mountains closer to the mining district which included Alburnus Maior (m. Roşia Montană) and Ampelum (m. Zlatna). Apulum benefited from its location in a fertile valley but its proximity to the gold mines supplied the wealth that resulted in the nickname of Chrysopolis or the city of gold. Indeed, Apulum would become one of the largest cities in all the Danube provinces. ${ }^{174}$ In testament to the urgency of production, the rustic foundations of many settlements date directly after Trajan's conquest, as early

\footnotetext{
${ }^{170}$ Oltean also adds that silver, copper and tin were likely mined as well although less pre-Roman evidence exists. Oltean, Dacia, 105, 181 and 201.

${ }^{171}$ Only one major Roman city, Romula, developed in the eastern area of the province where the natural resources were scarce. Haynes and Hanson, "Roman Dacia," 18.

${ }^{172}$ IDR I 1. Also see V. Mihailescu-Birliba, "Some inferences from the numismatic evidence across a Roman frontier segment (north-west of Dacia Porolissensis)," OXBOW MONOGRAPH 91 (1997): 241.

173 Diaconescu, “Towns of Roman Dacia,” 103.

${ }^{174}$ Chrysopolis appears in an inscription to Emperor Volusianus. AE (1989) 628. Diaconescu, "Towns of Roman Dacia," 109.
} 
as $107 / 8 \mathrm{CE}$, and there is evidence that Roman roads were connecting these "villages," like the future important centers of Potaissa and Napoca (m. Cluj-Napoca), in the infancy of their development. ${ }^{175}$

The province was partitioned throughout its history but the central region around Alburnus Maior was consistently united as the center of government and continued as the focus for most provincial activities. Dacia was attacked by the Sarmatians in 117/8 CE and Hadrian remitted some western territories before he reorganized the remaining province into three parts: Dacia Superior, Dacia Inferior and Dacia Porolissensis. ${ }^{176}$ In this new configuration, Dacia Superior remained the heart of the province as it contained the colony, legion, and rich resources while the other two provinces were garrisoned by auxiliaries and had smaller settlements. After the Marcomannic Wars (ca.167/8-180 CE) the provinces were again reorganized into Dacia Apulensis, Dacia Malvensis and Dacia Porolissensis. Dacia Apulensis, with a similar footprint to Dacia Superior, also maintained the colony, legionary bases and most of the mining works. Colonia Ulpia Traiana Sarmizegetusa continued to act as the financial and judicial center under a procurator and provincial parliament respectively. ${ }^{177}$ A senatorial governor at Apulum, the consularis trium Daciarum, controlled the military in all three provinces. Apulum replaced Colonia Ulpia Traiana Sarmizegetusa as the seat of power and two separate cities developed near the legionary base. During the wars the vicus two kilometers away

\footnotetext{
175 “Imp(erator) Caesar Nerva Traianus Aug(ustus) Germ(anicus) Dacicus pontif(ex) maxim(us) (!) pot(estate) XII co(n)s(ul) V imp(erator) VI p(ater) p(atriae) fecit per coh(ortem) I Fl(aviam) Ulp(iam) Hisp(anam) mil(liariam) c(ivium) R(omanorum) eq(uitatam) a Potaissa Napocam m(ilia) p(assuum) X. " dates 107-108 CE. CIL III $1627=$ ILD 536.

${ }^{176}$ This reorganization was completed by 120 CE. Haynes and Hanson, "Roman Dacia," 18-19.

${ }^{177}$ The $V$ Macedonica was based at Potaissa either during or after the Marcomannic Wars. Haynes and Hanson, "Roman Dacia," 19-20.
} 
became a municipium (Aurelium Apulense) under Marcus Aurelius (r. 161-180 CE) and afterwards a colonia (Aurelia Apulensis) by Commodus (r. 180-192 CE). The second city, the cannaba, became a municipium (Septimium Apulense) under Septimius Severus (r. 193-211 CE). ${ }^{178}$ The formation of both a colonia and a separate municipium in close proximity again highlights the wealth created in the region. Throughout these provincial administrative changes, Apulum and Colonia Ulpia Traiana Sarmizegetusa remained closely tied with the mining industry. The presence of legionaries and colonists from these larger urban centers influenced the administrative base at Ampelum and the mining community of Alburnus Maior.

Alburnus Maior was the main center at the heart of the mining district and connected the mining community to imperial officials from Ampelum and Apulum. The exact layout and functions of Alburnus Maior are unknown due to subsequent habitation and mining but the reference to the settlement in contracts suggests some administrative function and civic influence. The names of other smaller communities and material remains of settlements dotting the hillsides create a web of linked communities connected to Alburnus Maior at the center (see Map of Alburnus Maior in Appendix F). This mining region was connected via Roman road to the administrative center at Ampelum which served as the base for the procurator aurariarum who was initially a member of the imperial household, usually a freedman of the emperor. Although he and his staff undoubtedly visited the mines as part of their duties, their monuments and inscriptions were focused around Ampelum suggesting they identified with this community rather

\footnotetext{
${ }^{178}$ Usually decuriones were limited to one hundred in a city. The abundant number of decuriones in the epigraphic record of Apulum may suggest that both the colonia and municipium had one hundred each. Sotropa, Le droit, ix and xxi.
} 
than Alburnus Maior. Additionally, the legionnaires from Apulum were present in both Ampelum and Alburnus Maior. Their presence appears more often in the written record and a few military burials near the mines suggests some were laid to rest in a community that became a focus of their daily activities. Therefore, as a focal point for mineral wealth, Alburnus Maior was impacted by the ideas of the administration from Ampelum and military personnel from Apulum which influenced the development of identity within the mining community.

\section{Conclusion}

The Roman Empire did not expand through a consistent policy and the western Balkan and Danube provinces were created from a mixture of both diplomacy and war. Although the Roman literary tradition prefers to mark major events that build a growing narrative of the empire's success, these areas were incorporated inconsistently and often were revisited by revolt and unrest. The Romans quelled some of these indigenous groups by separating populations and moving them to other regions of the empire. This often served a double purpose as indigenous groups also provided labor in the growing extraction of resources for the empire. By the end of the first century CE, the Romans adopted the habit (if not the policy) of moving populations for control and profit.

The Romans were well aware of the material resources in Dacia through preconquest trade and the movement of merchants and specialists. The conquest of Dacia was unique for the substantial removal of the indigenous elite after years of conflict. After conquest, the new province became a magnet for colonists who participated in one of the largest colonization efforts in Roman history. Among their number were administrators, entrepreneurs, soldiers, and laborers who participated in the mining 
industry. Many came from the western Balkans and Danube provinces with different histories of conquest and varied experiences with the Mediterranean exchange. Together they would create a new immigrant community where the awareness of their association with the Roman Empire directly influenced the formation of public identities. 


\section{Chapter 3: Alburnus Maior in the Roman Empire}

The immediate awareness of the presence of the Roman Empire influenced daily life differently in each Roman community and province. Urban centers, political organization, and taxation often provide examples of the Roman impact on the conquered. At the mines, the continued presence of imperial freedmen and equites, the active participation by legionaries, and the increased levels of extraction through the utilization of new technologies created an additional level of Roman occupation.

The extent of a centralized policy dictated from the capital city of Rome to mining districts is debated. ${ }^{179}$ At the same time, the general assessment that the Roman Empire operated with "ad hoc yet functional" policies may not be accurate for mining operations either. ${ }^{180}$ Relatively uniform hierarchal structures adjusted to the particular challenges presented by a mine's location and available resources. There were two inherent concerns for mining organization: the operative processes (the procedures practiced by laborers) and the directive processes (planning and management of resources and personnel). ${ }^{181}$ Both of these could be handled at the local level. But the similarities between mining operations in the empire suggest that some intelligence and organization was shared between districts. There is no evidence to suggest that mandata, like those

\footnotetext{
${ }^{179}$ For further discussion see Slobodon Dušanić, "The Roman Mines in Illyricum: Organization and Impact on Provincial Life," in Minería y metalurgia en las antiguas civilizaciones mediterráneas y europeas, ed. Claude Domergue (Madrid: Ministerio de Cultura, 1989): 148-156.

${ }^{180}$ Sipilä also references Temin's theory that the Roman economy worked as a "conglomeration of interdependent markets." Instead, political structures were more influential in creating similarities than a centralized economic policy dictated from Rome. Sipilä, Reorganization of Provincial Territories, 5 and 72 .

${ }^{181}$ Hirt, Imperial Mines, 7.
} 
given to new governors, were provided to mining procuratores from Rome. ${ }^{182}$

Nonetheless, there was some network of knowledge that kept the emperor and his staff informed and either the emperor or his personnel proactively assigned posts and determined changes in policy with this intelligence. ${ }^{183}$ Many procuratores, both for mining districts and other appointments, were moved around the empire based on experience and need. ${ }^{184}$ Additionally, imperial slaves and freedmen at mines imply there was a strong attachment to the emperor who was keen to control state investments. ${ }^{185}$ Despite these ties to the center, state appointed administrators had to balance the realities of local circumstance with the expectations of the empire which limited any total uniformity between metalla (mining districts). ${ }^{186}$

In Dacia, the state regulations created by procuratores influenced the daily life of the miners, conductores (managers), and specialists working at the mines. An examination of how the district was administered and who was involved in the industry provides an outline for visualizing the public life at Alburnus Maior. The expressions of identity within the Roman state through cult, law, and language show how a rural community, albeit a unique one, communicated its role in the empire. Individuals within

\footnotetext{
${ }^{182}$ Only fragments of mandata for governors remain. Sipilä also creates a good case that the proximity of the emperor related more to his direct influence in a province and its economy. Sipilä, Reorganization of Provincial Territories, 48-49.

${ }^{183}$ In his expansive review of mines and quarries in the Roman Empire, Hirt noted that at least the costs of mines were well known by the emperor and/or his staff and changes in policy, such as how the mines were leased, or even the closure of mines could result. Hirt, Imperial Mines, 340.

${ }^{184}$ For example, T. Claudius Xenophon started his career as the procurator for the argentariarum Pannoniarum et Dalmatiarum and finished it with two higher fiscal appointments in Dacia. CIL III 7127.

${ }^{185}$ Hirt, Imperial Mines, 149-153.

${ }^{186}$ Although laws set by procuratores in other districts are informative, such as the second century CE lex Metalli Vipascensis (Vipasca) from Portugal, there were undoubtedly differences in policy at other districts based on the local circumstances such as type of laborers (predominantly free or unfree), environment, available resources, etc.
} 
these communities utilized Roman ideas to declare their state identity and maintain their rights within it.

\section{State Administration}

The gold mines of Dacia were an important asset to the Roman Empire and, as the property of the emperor, were closely controlled by his representatives. As part of the imperial fiscus, the profits were used for state, civil, and military expenses. ${ }^{187}$ Rather than directing every detail at the mines, most were managed through "indirect rule.", 188 The procurator and his staff regulated and leased the mining operations for the state but used taxes, fees, and policy to control production rather than dictate operations individually. ${ }^{189}$ This administrative style is applicable to Alburnus Maior. However, this indirect rule does not imply that the community was unaware of the presence of the empire, as mining operations and legal formalities were centralized under an imperial hierarchy.

\footnotetext{
${ }^{187}$ Hirt, Imperial Mines, 100. Although there is still some debate on this issue, most historians agree that these mines financed the state instead of the emperor privately. In part the debate stems from the fact that some mines were recorded as patrimonial property, or identified as the emperor's personal property which passed to his successor. Slobodan Dušanić, "Aspects of Roman Mining in Noricum, Pannonia, Dalmatia and Moesia Superior," in Aufstieg und Niedergang der Romischen Welt 2, no. 6, eds. Hidegard Temporini, Sechster Band, and Wolfgang Haase (Berlin: Walter de Gruyter, 1977) 81. Also, under the early Principate, some mines may have been awarded to the emperor's favorites who shared the profits. Slobodan Dušanić, "The Valle Ponti Lead Ingots: Notes on Roman Notables' Commercial Activities in Free Illyricum at the Beginning of the Principate," Starinar 58 (2008): 116.

${ }^{188}$ Direct imperial rule at mines (no leases) was less common and seen at mines where large waterworks were required, such as the massive alluvial works in Dalmatia and Northwest Spain. While Domergue argues that a hybrid of indirect and direct rule was more common in Noricum, Pannonia, Dalmatia and Moesia Superior, this mix of the two would likely fit Dacia as well. Claude Domergue, Les Mines Antiques: La production de métaux aux époques grecque et romaine (Paris: Picard, 2008) 200-203.

${ }^{189}$ The clearest example of this comes from the lex Metalli Vipascensis in second century Portugal. The laws dictate that the lease cost of a mining site was 4000 sesterces, paid to the fiscus. This was a flat fee as a leasee could sell their mining site to another entrepreneur for a higher price if they found a buyer and the fiscus already received its 4000 sesterces. In addition to fees, fines were also possible, such as 1000 sesterces for working at night which was strictly forbidden. Finally, more like a tax, the procurator collected half of all the mined ore before smelting. ILS 6891.
} 
Imperial mining districts, or metalla, were autonomous territories that were administered by procuratores. ${ }^{190}$ The first procurator aurariarum for Alburnus Maior was M. Ulpius Hermias, an Augusti libertus, or an imperial freedman, appointed by the emperor Trajan. ${ }^{191}$ Although freed from slavery, these men continued to serve the interests of the emperor. They often attained this high position at the peak of their career after serving the emperor's office for as long as thirty years. ${ }^{192}$ The procurator managed the operation of the mines similar to a project manager. In Dacia, the procurator aurariarum was based at Ampelum but likely traveled to areas of operations, especially those around Alburnus Maior, as required. ${ }^{193}$ The buildings with hypocausts at Alburnus Maior on Carpeni Hill were likely used for official business by the procurator or his staff. ${ }^{194}$ Although they may not have needed to know every detail of mining, procuratores regulated both mining activity and civic life around the mines. ${ }^{195}$ This included overseeing everything from safety and infrastructure in the mines to leasing access to conductores, or managers, and their crews. The details of many of the powers of the procurator are taken from the second century CE lex Metalli Vipascensis (Vipasca) from modern Portugal, a document that is considered applicable to most Roman mines at

\footnotetext{
${ }^{190}$ Hirt, Imperial Mines, 106.

${ }^{191}$ CIL III 1312. Dated to Trajan from S. Mrozek, "Die Goldbergwerke in römischen Dazien," in Aufstieg und Niedergang der Romischen Welt 2, no. 6, eds. Hidegard Temporini, Sechster Band, and Wolfgang Haase (Berlin: Walter de Gruyter, 1977) 67.

${ }^{192}$ Domergue, Les Mines Antiques, 197. Noeske estimates the average age was 40-45 years. HansChristoph Noeske, "Studien zur Verwaltung und Bevölkerung der dakischen Goldbergwerke," Bonner Jahrbücher 177 (1977): 296-297.

${ }^{193}$ Damian, Alburnus Maior I, 27 and Hirt, Imperial Mines, 165.

${ }^{194}$ Hypocaust construction heated the floor and walls by feeding a furnace that fed the hot air under the floor before it exited through shafts in the walls. Rare near Alburnus Maior, they were likely for administrative or elite housing. Damian, Alburnus Maior I, 432.

${ }^{195}$ Hirt, Imperial Mines, 257.
} 
this time. ${ }^{196}$ According to this statute, the procurator could also dictate punishment for crimes committed at the mines. Offenses such as stealing ore or damaging equipment could result in fines and even exile from the region. Daily life was touched as monopolies for services, such as those of barbers or shoemakers, could be purchased outright from the procurator. ${ }^{197}$ In Dacia, these procuratores also likely regulated the placement of public buildings and temples as well as the settlements of vici and kastella. $^{198}$

During the reign of Marcus Aurelius (161-180 CE) the office of procurator aurariarum in Dacia was transferred to equites, elites elevated by the emperor who often held officer posts and civil administrative positions. There was some overlap between the freedmen and the equites and it is possible the freedmen continued to monitor the mines on behalf of the emperor or split their duties between different mines. ${ }^{199}$ At the same time, the Marcomannic Wars (166-180 CE) caused disruption in the mining region and the position may have been redefined during the provincial reorganization. Perhaps the toll of the wars created a need to entice miners back to work with a change in administration and/or policy. Indeed, there are two apparent waves of immigration to the mines; the second begins after the Marcomannic Wars. ${ }^{200}$

\footnotetext{
${ }^{196}$ Domergue also notes that these laws were specifically for the silver mines rather than copper mines. This need for organization likely reflects the necessity and preference for certain precious metals. Hirt, Imperial Mines, 227 and Domergue, Les Mines Antiques, 68 and 198.

${ }^{197}$ ILS 6891.

${ }^{198}$ These small civil settlements that surrounded Alburnus Maior will be discussed more in Chapter 4. Damian, Alburnus Maior I, 289-290.

${ }^{199}$ Noeske, "Goldbergwerke," 299-301 and Mrozek, "Die Goldbergwerke," 97.

${ }^{200}$ Noeske, "Goldbergwerke," 316-317.
} 
Many minor offices under the procurator were held by equites, freedmen, slaves, peregrini, and soldiers. In Dacia, records were managed by the tabularii, or archivists, and the commentarii who also supervised official reports. Dispensatores handled money and paid bills for the procurator and librarii acted as secretaries. ${ }^{201}$ The presence of mining engineers or specialists was encouraged by the procurator. In the lex Metalli Vipascensis both underground supports and drainage systems receive special attention as necessary to mining operations and policy dictates their maintenance and protection. ${ }^{202}$

Conductores often associated with tax farming and customs collection were more akin to overseers or general managers who leased a mine, usually for an affluent patron or corporation of wealthy investors, and directed the miners in their work. ${ }^{203}$ They contracted directly with the procurator and were responsible for communicating policies and regulations to the miners. The miners entered wage contracts directly with the conductor and he then became their official contact with the state administration. ${ }^{204}$ Policies set by the procurator directly influenced how conductores managed mining labor. For example, at the mines in Vipasca, a conductor could lose the mine he leased if work ceased more than ten days. At the same time, the conductor could be penalized if

\footnotetext{
${ }^{201}$ Noeske, “Goldbergwerke,” 309-311.

${ }^{202}$ ILS 6891.

${ }^{203}$ Peter Garnsey and Richard P. Saller, The Early Principate: Augustus to Trajan (Oxford: Clarendon Press, 1982) 15-16 and Dise, Imperial Administration, 81. Unlike other enterprises, it was legal for partnerships to form corporations to invest in gold, silver, and salt mines according to Ad edictum provinciale by Gaius. Hirt, Imperial Mines, 91.

${ }^{204}$ CIL III pp.948-949 and p.952 Tablets IX, X, XI, and XIV.
} 
he kept his crew working longer shifts since working through the evening hours was explicitly forbidden. ${ }^{205}$ Both policies would impact the hours worked by miners.

Military personnel also contributed service in the mining district. As a province at the edge of the empire, Dacia remained heavily defended. Evidence of as many as sixty auxiliary units and two legions has encouraged high estimates of active duty soldiers as many as 55-60,000 in the province. ${ }^{206}$ The most obvious benefit these soldiers provided was security. While legions could be dispatched as needed, auxiliaries, who where themselves new members of the empire that did not yet possess Roman citizenship, often manned forts in more rural areas. These auxiliaries usually became the primary contact rural populations had with Roman administration. While they assured peace in the countryside, they were also used to enforce tax collection and regional custom duties. ${ }^{207}$ A dedication by Felix Caesaris, an imperial freedman, provides evidence of a customs office located at the auxiliary fort Micia near the iron mines of the Poiana Rusca Mountains in Dacia. ${ }^{208}$ At mines throughout the empire soldiers also provided extra security to guard convict labor and prisoners of war and protected the movement of precious metals as needed. ${ }^{209}$

\footnotetext{
${ }^{205}$ The prohibition against working evenings was to prevent theft - but indirectly it would also impact the miners' shifts. ILS 6891.

${ }^{206}$ Oltean, Dacia, 217 and Diaconescu, "Towns of Roman Dacia," 120.

${ }^{207}$ Roy W. Davies, David John Breeze, and Valerie A. Maxfield, Service in the Roman Army (New York: Columbia University Press, 1989) 56 and Diaconescu, “Towns of Roman Dacia," 127-128.

${ }^{208}$ CIL III $7853=$ IDR III/3 102. The ala I Hispanorum Campagonum, cohors II Flavia Commagennorum and the numerous Maurorum Miciensium were stationed at the fort Micia where a substantial vicus developed. Oltean, Dacia, 217-218 and 161.

${ }^{209}$ Davies, Roman Army, 63.
} 
At Ampelum and Alburnus Maior, most evidence points to the presence of legionaries from the legio XIII Gemina stationed at Apulum who supported both administration and infrastructure. The provincial governor usually had 100 personnel from each legion in their province who acted as beneficiarii, or junior officers who aided in administration. ${ }^{210}$ Some of these beneficiarii are well attested at Alburnus Maior where they found it important to make dedications near the community (see I.O.M. Table in Appendix B). Legionnaires might also aid in such civil tasks from taking the census to providing the special skills of an interpreter or engineer. ${ }^{211}$ Their expertise could involve administrative duties for the mining procurator. For example, M. Aurelius Antoninus and P. Helvius Primanus were both from the XIII Gemina and each acted as librarii, or secretaries, for the mining administration at Ampelum. ${ }^{212}$ A specific skill set might influence the placement of a soldier away from his unit, sometimes a legionary was moved to mines across the empire by the emperor's command. ${ }^{213}$ For example, Ti. Claudius Proculus Cornelianus of the II Italica served as a procurator for the mines in Syria, then the Danube Provinces, then Spain and finally in northern Africa during his long career. ${ }^{214}$ Entire auxiliary units might also be stationed due to their expertise such as

\footnotetext{
${ }^{210}$ Boris Rankov, "The Governor's Men: The officium consularis in Provincial Administration," in The Roman Army as a Community, eds. Adrian Keith Goldsworthy, Ian Haynes, and C. E. P. Adams (Portsmouth: Journal of Roman Archaeology, 1999) 25 and 27.

${ }^{211}$ Davies, Roman Army, 37. Evidence of soldiers with knowledge of Dacian (interpres Dacorum) has been found in Lower Pannonia and it is not hard to believe that similar interpreters would be at work in the new province as well. Daniel Peretz, "The Roman Interpreter and His Diplomatic and Military Roles," Historia: Zeitschift für Alte Geschichte 55 no. 4 (2006): 453-454. Rankov also notes that in Dacia the knowledge of German and Sarmatian would be also be required due to its position on the frontier. Rankov, "The Governor's Men," 22.

${ }^{212}$ CIL III 1317 and 1318.

${ }^{213}$ Wilkes, Dalmatia, 122 and Hirt, Imperial Mines, 332.

${ }^{214}$ Hirt, Imperial Mines, 246. AE (1956) 123.
} 
the $2^{\text {nd }}$ Cohort Austurian (from the gold region of northwest Spain) which was placed near mines in Britain. ${ }^{215}$ Despite any acquired knowledge of mining, it is doubtful that soldiers were used as miners. Dispatches of soldiers sent to the mines do not detail their duties but most epigraphic evidence suggests that their roles were defensive and administrative and that their labor was better directed towards building projects. ${ }^{216}$

Soldiers built roads, official buildings, and aided infrastructure by utilizing both their manpower and expertise in building techniques and project management. ${ }^{217}$ Although based at Apulum the bricks stamped by the XIII Gemina at Alburnus Maior and Ampelum have provided evidence of their building activities near the mines. Stamps were used to mark who owned and manufactured bricks. They do not necessarily indicate who constructed the structures made with them. But legions were well known for building activities and the construction with Roman architectural forms at Alburnus Maior, such as buildings with hypocaust systems, used 'LEG XIII GEM' stamped bricks which suggests legionaries were likely involved. ${ }^{218}$ Additionally, the bricks were made of the same base materials but fired at different temperatures at Apulum and Alburnus Maior. ${ }^{219}$ This eliminates the chance that the soldiers were working from one factory in

\footnotetext{
215 Thompson, Greek and Roman Slavery, 177

${ }^{216}$ A record of the Cohors I Hispanorum from Lower Moesia in 105 CE states simply, "in Dardania at the mines" next to the soldier's reported location. Davies, Roman Army, 35 and Andreau, "Les mines romaines," 92-93.

${ }^{217}$ Hirt, Imperial Mines, 201 and W.S. Hanson, "Building the Forts and Frontiers," in The Army and Frontiers of Rome: Papers Offered to David J. Breeze on the Occasion of his Sixty-Fifth Birthday and his Retirement from Historic Scotland, eds. W.S. Hanson, Lindsay Allason-Jones, and David John Breeze (Portsmouth: Journal of Roman Archaeology, 2009) 34.

${ }^{218}$ Damian, Alburnus Maior I, 431-432.

${ }^{219}$ Corina Ionescu, Lucreţia Ghergari and Ovidiu Țentea. "Interdisciplinary (Mineralogical-GeologicalArchaeological) Study on the Tegular Material Belonging to the Legion XIII Gemina from Alburnus Maior
} 
Apulum and shipping bricks to other areas. Instead, they were involved in or overseeing the manufacture of bricks in the mining community. The manufacture of these bricks at Alburnus Maior provides further evidence that the soldiers were employed in activities at the mines. ${ }^{220}$ These stamps are connected with settlement sites and official buildings rather than military installments and date from the early second century CE suggesting the legion was involved in the development of the mines from the beginning of Roman occupation. $^{221}$

Finally, the combined effort of imperial administrators and the military provided miners access to goods and ideas through policy and the construction of infrastructure. Mining communities are often considered isolated from urban culture and tradition. Rural communities often had less access to commercial goods and new ideas that had a large impact on changing identities. But mining officials wanted to keep miners well supplied and in place. At the mines, the daily products used were a mixture of Roman and local manufacture but reflect a shift toward the import of cheap and ready-available items. Before conquest, higher elevation sites worked self-sufficiently and made items such as pottery and iron tools as needed. ${ }^{222}$ Under the organization by Roman administration, household items were supplied so miners could spend more time working.

(Roşia Montană) and Apulum (Alba Iulia): Possible Raw Materials Sources," Cercetări Arheologice 13 (2006): 413 and 430.

${ }^{220}$ The only clearly identified fortification at Alburnus Maior is at Abrud-Cetăţuia point. Damian, Alburnus Maior I, 443.

${ }^{221}$ Stamps are at Balea, Tomuş, and Bisericuţă settlements. Hirt, Imperial Mines, 41. The building with the hypocaust was likely a structure for an official. Noeske has suggested similar buildings at other mining sites, such as Domavia, were likely used by officials and their families. Noeske, "Goldbergwerke," 288. LEG XIII GEM (GE and G) type stamps date this early. Ovidiu Țentea, "Legion XIII Gemina and Alburnus Maior," Apulum 40 (2003): 256. The stamps were also used in Pannonia earlier than this date suggests these stamps were some of the earliest used in this area. Damian, Alburnus Maior I, 431-432.

${ }^{222}$ Oltean, Dacia, 74. 
Only small furnaces have been found which were used to forge tools and items on a limited basis. ${ }^{223}$ Most household ceramics were manufactured by Roman provincial factories while there remained only intermittent local and "poor quality" products. ${ }^{224}$ Oil lamps were imported for work, home, and religious life. ${ }^{225}$ Workshops in urban centers like Ampelum and Apulum encouraged low prices and a steady supply. ${ }^{226}$ Other than a small seasonal garden, most crops were also imported into the mining region. Vici and villas worked the rich farmland of the Mureş Valley around Apulum and Ampelum. Surplus was not exported from Dacia but supported the military, administration, and the mining community. ${ }^{227}$ Meat was imported from local pastoralists as is noted on the wax tablet contract found at Alburnus Maior noting the purchase of lambs and pigs. The itemized list on Tablet XV cost 166/9 denarii and shows a number of bulk items such as

\footnotetext{
${ }^{223}$ Again, as stated in Chapter 2, a much larger industrial site has not been found and may be lost due to subsequent mining activity. However, smaller ore furnaces, with no slag, have been found at Găuri site. Damian, Alburnus Maior I, 47.

${ }^{224}$ Archaeologists generally record Roman ceramics at Alburnus Maior but some non-Roman items used for food preparation have also been found at a few sites like Tăul Țapului. This does not mean Dacian, just local manufacture using simpler techniques and materials. Damian, Alburnus Maior I, 88-89. This preference for cheap Roman goods happened in other rural areas of Dacia where communities with indigenous Dacian populations imported Roman pottery in preference to locally made goods. At Obreja Dacian pottery is only $10-15 \%$ of the inventory although the settlement continues other Dacian material culture. Interestingly, the community also adopted Roman tools and a bread oven but did not change their architecture from pre-Roman styles. Oltean, Dacia, 145-147.

${ }^{225}$ Many different lamps are found around Alburnus Maior including OCTAVI, Litogenes and FORTIS. Damian, Alburnus Maior I, 389, 446 and 503. Over forty different styles of lamps have been found in Dacia and popular forms, especially those from northern Italy, were often forged to meet local demand. C.C. Petolescu, "Les relations économiques de la Dacie Romaine," Memorias de Historia Antiqua 4 (1980): 54.

${ }^{226}$ Oltean, Dacia, 197. The last rescue dig at Ampelum before the sites destruction turned up pottery kilns in a possible villa factory. Popa, "Ampelum (Zlatna)," 115.

${ }^{227}$ Diaconescu argues that despite the rich area, Dacia was not known for grain exports and most of these crops were locally consumed. Diaconescu, "Towns of Roman Dacia," 120. For the cooperation between villas and farms in Dacia, see Oltean, Dacia, 180.
} 
vinegar, salt, and white bread. ${ }^{228}$ This purchase was made through one merchant who likely paid a fee to the procurator for permission to trade in the community as seen at Vipasca. $^{229}$ Finally, it is possible the bread ovens found at Alburnus Maior were also controlled through a similar lease for the communities. ${ }^{230}$ Again this suggests every effort was made to supply the miners and focus their labor on mineral exploitation.

This partnership between rural settlements, like mining communities, and the larger urban centers provided cheaper goods and more access to services. Normally this exchange did not expand distances beyond 10-15 kilometers. ${ }^{231}$ Apulum was 75 kilometers and Ampelum 35 kilometers away from Alburnus Maior which generally would put their services and goods beyond everyday reach. ${ }^{232}$ Despite these distances and the increased difficulty and elevation of the Roman road, many bulk items and services still found their way to the mining center. ${ }^{233}$ Blown glass was imported from Apulum and was used in household and funerary practices. ${ }^{234}$ Few personal items remain in the domestic spaces but mirrors, small bronze tools, and glass tubular unguentaria have been found which were not locally manufactured. ${ }^{235}$ Again, as mentioned above, pottery was also largely imported. The use of standard altar forms combined with an

\footnotetext{
${ }^{228}$ Frankincense was also purchased and taken in whole with the other items may suggest a purchase for a religious event. CIL III p. 953 Tablet XV.

${ }^{229}$ ILS 6891.

${ }^{230}$ Oltean, Dacia, 160.

${ }^{231}$ Oltean, Dacia, 197.

${ }^{232}$ Baron, "Lead isotope," 1098.

${ }^{233}$ Țentea, "Legion XIII Gemina," 258.

${ }^{234}$ Florescu, Art of Dacian-Roman, 135.

${ }^{235}$ Damian, Alburnus Maior I, 384 and 487.
} 
inconsistency of engraving suggests altars were manufactured in Ampelum or Apulum and then engraved at Alburnus Maior. ${ }^{236}$ A combination of available cash used by the miners, protected markets, and the interest of administrators to keep miners equipped (and in place), encouraged the import of needed and even desired goods. In essence this was a connected but closed rural community.

The awareness of the Roman Empire at the mines was primarily established through handpicked imperial administrators and the continued presence of legionaries. Their proximity in this rural community ensured clear hierarchical structures and provided examples of legal and fiscal standards. Mining activity was governed by the procuratores and their staff ensured documentation for the imperial fiscus. Most miners would not know the procurator directly but were made aware of expectations and deadlines by their conductores who had to comply with Roman regulations.

Additionally, while legionnaires worked within this administrative structure, they also provided examples of Roman architecture and religious dedications near the mines.

Finally, access to new and cheap goods was facilitated by the combined efforts of the procurator, his staff, and the legionaries in an effort to keep the miners focused on their labor. Under this state administration were private entrepreneurs and colonists who also participated.

\footnotetext{
${ }^{236}$ The same pattern is seen in Moesia Superior where rural areas had access as long as there was a demand. Mócsy, Pannonia and Upper Moesia, 179-180. Apulum was very influential in the art forms of stelae in the region. While every form found in Dacia is present in Apulum, the extenuated "baroque style" carving popular in the area likely came from Apulum. Lucia Țeposu-Marinescu, Funerary Monuments in Dacia Superior and Dacia Porolissensis (Oxford: B.A.R., 1982) 70.
} 


\section{Colonists and Dacians}

Citizens, civitates peregrinae (foreign residents), and slaves participated in several aspects of the mining industry. Because social and economic mobility was not limited by citizenship status there, Alburnus Maior is an informative case study in how these identities could be negotiated in immigrant communities.

Those with the least amount of direct involvement, but likely the greatest chance for profit, were the wealthy elite who invested in the development of the mines or related infrastructure. Although leasing mines was not ideal, "since the greatest part [of the labor] is accomplished through criminals or barbarians," the use of technology, prospective profits, and legal ability to form corporations (not always allowed), reduced the stigma normally attached to this industry. ${ }^{237}$ In fact, there is no evidence in Dacia that there were concerns over the propriety of engaging in mining ventures. Most of the wealthy colonists, many with Roman citizenship, remained at the urban centers of Colonia Ulpia Traiana Sarmizegetusa, Apulum, and Ampelum where they contributed to the public monuments and infrastructure. ${ }^{238}$ Their investment in the mines was practical such as P. Celsenius Constans a decurionus, or member of local council, both in Dalmatia and then Dacia, who brought mining specialists to Dacia from Dalmatia. ${ }^{239}$ These

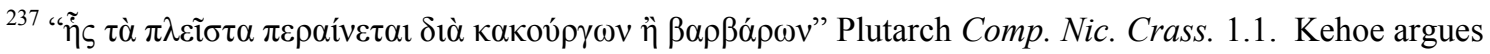
that the use of technology countered the stigma attached to participation in other industries. Dennis P. Kehoe, "The early Roman Empire: Production," in The Cambridge economic history of the Greco-Roman World, eds. Walter Scheidel, Ian Morris and Richard P. Saller (Cambridge, UK: Cambridge University Press, 2007) 567-568. If the lex Metalli Vipascensis can again serve as a gauge, in Portugal investors were allowed to keep half of the extracted silver and copper. It may have been less for gold. ILS 6891.

${ }^{238}$ While most colonists in the colony were awarded with ius Italicum, Apulum would not receive this right until Emperor Septimius Severus (193-211 CE). Oltean, Dacia, 199 and 221.

${ }^{239}$ Diaconescu, “Towns of Roman Dacia,” 122 and CIL III 1323.
} 
investors commissioned others, such as conductores, to oversee the actual mining activities.

Conductores (managers) often managed investments for the elite or gained enough wealth to run their own projects. Some served in urban government as decuriones and a few had enough money to be members of the equites order. ${ }^{240}$ Due to this fluctuation of social status and wealth, conductores participated in a number of mining investments with different levels of responsibility. P. Aelius Strenuus, an equites from Apulum, was a conductor and decurionus who acted as patron to artisans, textile manufacturers, and river boatmen (usually associated with trade). He also managed farmers and salt miners (possibly at an earlier point in his long career). ${ }^{241}$ Meanwhile, other conductores, who were not as wealthy, continued to contract mining labor at Alburnus Maior. For example, the conductores listed in the contracts hiring wage laborers were doing so from Alburnus Maior and smaller settlements around the mining center, such as Immenosus Maior, rather than at the larger towns of Ampelum or Apulum. $^{242}$

At the initial colonization of the mining district, the majority of miners working at Alburnus Maior did not have Roman citizenship but were instead civitates peregrinae. These foreign citizens were usually the recently conquered who had attained some level of self-representation through their native elite or principes who often gained citizenship

\footnotetext{
${ }^{240} \mathrm{P}$. Aelius Strennus was a member of the equites order which would have required an estimated 400,000 sesterces. CIL III 1209.

${ }^{241}$ CIL III 1209. Note, Strennus uses the title conductor on his monument, "conduc(tori) pascui salinar(um)."

${ }^{242}$ CIL III p.948 Tablets IX and X.
} 
status before their compatriots. ${ }^{243}$ Indeed, peregrine residents could use their own local laws and administration structures as long as they correlated to the Roman system and worked to meet Roman expectations for taxation and service. ${ }^{244}$ Some principes moved with peregrini from their home region and provided representation for them. T. Aurelius Aper, who was commemorated at Ampelum, was a representative of the Delmatae from Dalmatia. $^{245}$ Not all principes were citizens. Maximus Veneti was a peregrinus princeps who stood as witness for a sale of a slave girl near Alburnus Maior. ${ }^{246}$ Nevertheless, most of the peregrini at the settlements of Alburnus Maior were not members of the elite.

Due to the arduous work and dangerous conditions, ancient miners are usually associated with slaves, damnati (criminals), and the "depressed sectors" of the population. ${ }^{247}$ The gold mines at Dacia provide an example where free men willingly contracted themselves for a wage that far surpassed manual and farm labor. A comparison between the quarry workers at Mons Claudianus in Egypt and the miners at Alburnus Maior, shows comparable wages were paid in year and six month contracts for both. These salaries were higher than the wages earned by day laborers. ${ }^{248}$ At 70 denarii

\footnotetext{
${ }^{243}$ Mócsy, Pannonia and Upper Moesia, 134.

${ }^{244}$ Sotropa, Le droit, 160.

${ }^{245}$ Note the tria nomina was granted during/after Marcus Aurelius. CIL III 1322. Dušanić notes that the principes in the other Danube provinces also acted as intermediaries with Roman administration at mines which ensured production and promoted their own position. Slobodan Dušanić, "Late Roman Mining in Illyricum: Historical Observations," in Ancient mining and metallurgy in Southeast Europe: International Symposium Donji Milanovac, May 20-25, 1990, 247-270 (Belgrade: Archaeological Institute, 1995) 262.

${ }^{246}$ CIL III pp. 937-939 Tablet VI. As will be discussed in Chapter 5, Maximus was a popular Latin name adopted into the Illyrian naming conventions at Alburnus Maior and the name here followed by the father's name in genitive strongly suggests this princeps did not have Roman citizenship. Also, as will be discussed at the end of this chapter, at Alburnus Maior witnesses did not need to be citizens.

${ }^{247}$ M.I. Finley, The Ancient Economy (Berkeley: University of California Press, 1973) 72.

${ }^{248}$ Helene Cuvigny, "The Amount of Wages Paid to the Quarry-Workers at Mon Claudianus," The Journal of Roman Studies 86 (1996): 145.
} 
for half a year's labor, miners earned a salary comparable to an auxiliary solider or a little less than half the salary of a legionary. ${ }^{249}$ But provisions for food, clothing, shelter, and tools are not specified. ${ }^{250}$ Also, these miners lost money if they missed work and could be penalized with additional fines. ${ }^{251}$ Even with these expenses, the price of foodstuffs at Alburnus Maior noted on wax tablet XV (including lamb, pork, bread, and vinegar), suggest a miner could feed a family and still have enough money for other small expenses. ${ }^{252}$ The contract between Memmius and the conductor Aurelius Adiutor also specifies that the miner could receive his pay in installments. ${ }^{253}$ Evidence of bronze and brass coins found around Alburnus Maior suggest that the miners were paid some salary and did not live entirely on credit. ${ }^{254}$

\footnotetext{
${ }^{249}$ Noeske notes that auxiliaries were paid 100 denarii per year and Duncan-Jones provides the average wage of the legionary soldier c.85-c.200 CE at 1200 sesterces per year (or 300 denarii). At Alburnus Maior Memmius contracted half a year (180 days) as a miner for 70 denarii (Tablet X) - if Memmius's wage could be simply doubled for one year, then he could have made more than an auxiliary soldier. Six months earlier Socratio Sacritus contracted a little over a year (388 days) for 90 denarii, 10 less than the auxiliary wage provided (Tablet IX). Richard Duncan-Jones, The Economy of the Roman Empire: Quantitative Studies (Cambridge: Cambridge University Press, 1974) 10; Noeske, "Goldbergwerke," 75; CIL III p.948 Tablets IX and X.

${ }^{250}$ Pick axes have not been found in domestic spaces suggesting that they were held by the conductores or other officials. However, lamps, which are abundant, seem to be more personal as they accompanied the miner to light his way from home through the tunnels. Inscriptions were scratched on after they were fired, personalized with symbols, names, and possibly initials. Damian, Alburnus Maior I, 481-482.

${ }^{251} 5$ sesterces and 8 asses per day of lost work. CIL III p.948 Tablet X.

${ }^{252}$ For example, Noeske believed there were baths at Ampelum that the miners could access with these extra funds. Noeske, "Goldbergwerke," 76. On the tablet some prices were: five lambs for 18 denarii, pork for 5 denarii, white bread for 2 denarii and vinegar for $1 / 2$ a denarius. The purchase was likely for a religious festival. CIL III p.953 Tablet XV.

${ }^{253}$ CIL III p.948 Tablet X.

${ }^{254}$ G.L. Duncan, Coin Circulation in the Danubian and Balkan Provinces of the Roman Empire, AD 294578 (London: Royal Numismatic Society, 1993) 166-167 and 171 and Damian, Alburnus Maior I, 209. Dušanić notes that mining coins were less in value and may not have traded well outside the mining community in other Danube provinces. To my knowledge there is not a study of the coins found at Alburnus Maior that suggests they were of lesser value than those used in Ampelum or Apulum. Dušanić, "Aspects of Roman Mining," 62-63.
} 
The status of indigenous labor at the mines is less clear. In other areas of the empire, such as Hispania Tarraconensis and Moesia Superior, newly conquered peregrini were "obliged to work" in the mines. ${ }^{255}$ Florus also states that Vibius forced the "savage" Dalmatians to work in the gold mines after conquest. ${ }^{256}$ A relocation of Dacians to work at the mines cannot be verified since a clear post-conquest Dacian settlement has not been found and dated. But recent surveys note geometric tunnels that are unique to Dacia that can be carbon dated from before and after Roman conquest. It is possible Dacian miners remained active in the area. Because these tunneling techniques were not changed for some galleries, it is also possible these mines remained under Dacian supervision but worked within the new Roman administration. ${ }^{257}$ Besides conscripted or free labor, there is also the chance that the Dacians became a source of slave labor as prisoners of war. Again there is no direct evidence, but the use of prisoners of war at mines directly after conquest was not unknown in the empire.

The amount of participation by slaves in mining activities is uncertain. As already seen, imperial slaves worked directly in mining administration for the emperor. Although these slaves were of a lower legal status than freedmen and civitates peregrinae, they often had more funds (peculium) and could even afford to buy their own slaves. $^{258}$ More typically, slaves were used for labor. At other mines in the empire,

\footnotetext{
${ }^{255}$ Quote from Slobodon Dušanić, "Army and Mining in Moesia Superior," in Kaiser, Heer und Gesellschaft in der Römischen Kaiserzeit, eds. Géza Alföldy, Brian Dobson, and Werner Eck (Stuttgartt: Franz Steiner Verlag, 2000): 344. Discussions of Spain include the Astures in the northwest who may have been enslaved by Augustus to work in the mines or "compelled" to work there. Hirt, Imperial Mines, 4 and Thompson, Greek and Roman Slavery, 161.

256 "efferum genus" Flor. 2.25.

${ }^{257}$ Recent carbon dating has also verified this continuation. Damian, Alburnus Maior I, 503.

${ }^{258}$ Noeske, "Goldbergwerke," 306.
} 
slaves made up a large workforce and could be purchased as teams by one conductor from another. ${ }^{259}$ Dangerous and unskilled tasks were often performed by slaves at mines. The large water wheels, like those found at Dacia, were run by slave labor at other mines in the empire operating at a similar scale. ${ }^{260}$ The presence of wage labor at Alburnus Maior may have influenced the number of slaves. The provisions of food, shelter, and clothing, even when a slave was too sick to work, made them more expensive than wage earners who did not get paid for lost days. ${ }^{261}$ While there is not concrete evidence for a large slave labor force at Alburnus Maior, a monument at Ampelum which differentiates between dedicators who are liberti (freedmen) and leguli aurariarum (gold pickers) could possibly suggest the latter were slaves. ${ }^{262}$ Also in one of the wax tablet contracts, Secundus, the slave of Cassius Palumbus, enters a partnership on his master's behalf for 267 denarii. ${ }^{263}$ Unfortunately, while the contract mentions that the profits were to be split evenly, it does not directly state the partnership was a mining venture.

The immigrants to the Dacian gold mines came from different backgrounds that highlight the mobility of participants in the mining industry. Diodorus Siculus describes Italians flocking to the mines in Spain as both investors and conductores. ${ }^{264}$ Strabo's account of the Noricum gold rush provides a later echo of similar excitement and notes

\footnotetext{
${ }^{259}$ Slobodan Dušanić, "Prosopographic Notes on Roman Mining in Moesia Superior: The Families of Wealthy Immigrants in the Mining Districts of Moesia Superior - Summary." СТАРИНАР 56 (2006): 102.

${ }^{260}$ Thompson, Greek and Roman Slavery, 173 and 179.

${ }^{261}$ Noeske, "Goldbergwerke," 343.

${ }^{262}$ CIL III 1307.

263 "Secundus Cassi Palumbi servus a[ctor] intulit * ducentos sexaginta septem ” CIL III p. 951 Tablet XIII, 9-11.

${ }^{264}$ Diod. Sic. 5.36.3-4.
} 
that the gold was so plentiful that Italians were willing to work as miners themselves. ${ }^{265}$ The gold rush in Dacia mobilized a similar movement. However, the means for traveling 650 kilometers or more is uncertain. ${ }^{266}$ Road construction was slower in remote areas, but the connections between Pannonia, Dalmatia, and Moesia Superior were aided at the end of the first century CE by the preparations for the Dacian Wars. ${ }^{267}$ Once conquered, road and river routes were quickly developed by the army and the use of river travel, considered faster and cheaper, was established along the Mureș River valley. ${ }^{268}$ A few wealthy entrepreneurs may have independently followed the army as they constructed these earliest roads. In Britannia, Nipius Ascanius, a mining conductor, followed the

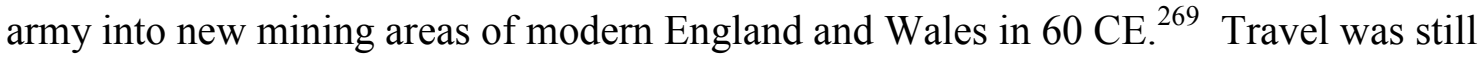
costly even when easier routes were developed. Some records of individual travel from Egypt record that soldiers and their wives were spending between 54-60 drachmas (roughly equal to denarii) for river journeys that were 480 kilometers. Most civilians

\footnotetext{
${ }^{265}$ Strabo 4.6.12. Hirt in his expansive review of mines and quarries in the Roman Empire notes that gold and silver mines, became, "focal points of migration." Hirt, Imperial Mines, 366.

${ }^{266}$ This distance was calculated "as the crow flies" using Google Maps Distance Calculator between modern Obrovac, Coratia (near the ancient site of Ansium) and modern Roşia Montană, Romania (Alburnus Maior). With modern roads the distance jumps to over $1000 \mathrm{~km}$. www.daftlogic.com/projects-googlemaps-distance-calculator.htm.

${ }^{267}$ Petar Petrović, Roman Limes on the Middle and Lower Danube (Belgrade: Archaeological Institute, 1996) 27.

${ }^{268}$ Roads north of Apulum between Potaissa and Napoca have already been dated to $108 \mathrm{CE}$ using the milestone raised by the cohors I Flavia Ulpia Hispanorum. Florin Fodorean, "Viae militaris in Dacia during Trajan - Abstract," DACIA AVGVSTI PROVINCIA: Crearea provinciei, actele simpozionului desfăşurat (October 2006): 1. For discussions on the speed and cost of river travel see Mócsy, Pannonia and Upper Moesia, 122-123 and Oltean, Dacia, 26 and 194.

${ }^{269}$ William S. Hanson, "Civilians on Frontiers," in Limes XIX: Proceedings of the XIXth International Congress of Roman Frontier Studies held in Pécs, Hungary, September 2003, eds. Zsolt Visy and Pécsi Tudományegyetem (Pécs: University of Pécs, 2005): 304.
} 
would not be able to afford this cost and group travel was likely the common practice. ${ }^{270}$ It is possible some conductores, like Nipius Ascanius, followed opportunity with a hired crew already familiar with Roman methods and expectations. ${ }^{271}$ In the case of Dacia, contracted miners technically could pay their travel expenses out of their wages in less than a year. Since they contracted directly with the conductor, it is possible their labor was sometimes bargained initially in their home province. It has also been suggested that at the very early stages the emperor funded transportation of laborers contracted by his procurator aurariarum. ${ }^{272}$

The initial movement of miners into the region was possibly under the emperor's order and, perhaps more importantly, with the aid of his funds. The movement of indigenous laborers by order of the emperor is mentioned at the development of other mines. The Asturians in northern Spain and the Dalmatians in the Vrbas Valley of Dalmatia were forcibly moved to mining districts. ${ }^{273}$ Eutropius also writes that Trajan moved people from the whole Roman world to Dacia to promote urbanization and agriculture. ${ }^{274}$ The level of organization and speed of colonization makes central control plausible but the impact of the wealthy elite and their corporations also likely played a role. $^{275}$ But the quick establishment of mines in new territories wherever resources were available suggests the emperor or his staff would not sit idly by waiting for elite

\footnotetext{
${ }^{270}$ C.E.P. Adams, "There and Back Again: Getting Around in Roman Egypt," in Travel and Geography in the Roman Empire (London: Routledge, 2001) 147.

${ }^{271}$ Mattingly, Power and Identity, 174.

${ }^{272}$ Mrozek, "Die Goldbergwerke," 109.

${ }^{273}$ Hirt, Imperial Mines, 334.

274 “ex toto orbe Romano infinitas eo copias hominum transtulerat ad agros et urbes colendas." Eutr. 8.6.2.

${ }^{275}$ Dušanić, “Aspects of Roman Mining,” 93 and Noeske, “Goldbergwerke,” 342.
} 
entrepreneurs to make an investment. The combined efforts of metallum administration and military manpower aided any imperial orders to move whole communities. At the same time, "gold rush" attitudes encouraged the mobility of conductores, specialists, and miners. The employment contracts from the late 160s CE are often used in arguments for free wage labor. This does not necessarily set the only precedent for mining labor in Dacia. ${ }^{276}$ It is likely a combination of the two took place with forced resettlement in the beginning and a later shift to contractual work after a large enough labor force was in place.

Once in Dacia, the various administrators, clerks, legionnaires, entrepreneurs, conductores, and miners left behind written evidence of their presence in Ampelum and Alburnus Maior. The occupations listed in Table 3.1 provide a short summary to the roles present in the mining district. ${ }^{277}$ The list does not include all the records available but provides selected examples that illustrate status and location. Most of the evidence for administrative personnel comes from Ampelum where the procurator and his staff kept their headquarters. As mentioned above, it is likely they also traveled to Alburnus Maior on occasion despite their absence from the local evidence. At Alburnus Maior there is evidence of legionaries, scribes, conductores, and principes who worked more closely with the miners. The actions and presence of state officials as well as the maintenance of a local hierarchy influenced the miners' perception of membership in the Roman Empire.

\footnotetext{
${ }^{276}$ This argument appears in Noeske, "Goldbergwerke," 342 and again in Hirt, Imperial Mines, 233-235.

${ }^{277}$ Not every position is evident. For example, special skills such as engineering or carpentry are not listed but there is clear evidence from the mines that complex hydraulic devices were used. Likely these skills were secondary to other positions, i.e. legionaries did not list these skills.
} 


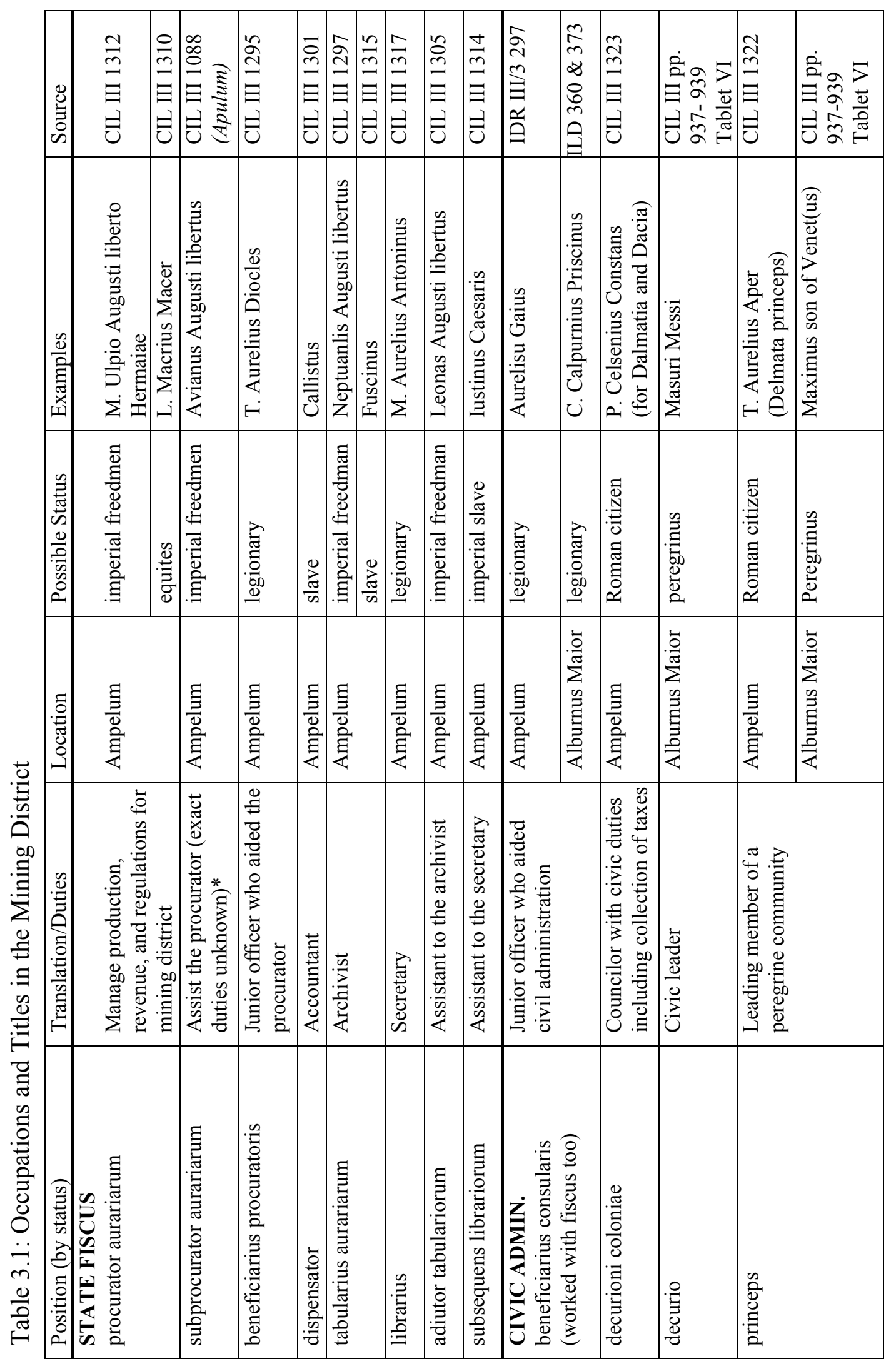




\begin{tabular}{|c|c|c|c|c|c|c|c|c|c|}
\hline $\begin{array}{l}0 \\
0 \\
0 \\
\vdots \\
0\end{array}$ & $\begin{array}{l}\vec{\Xi} \\
\stackrel{\Xi}{\Xi} \\
\exists\end{array}$ & 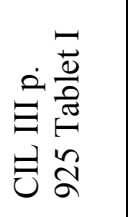 & 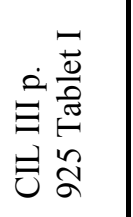 & 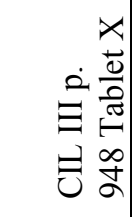 & 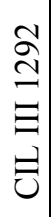 & 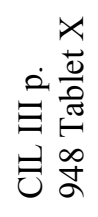 & 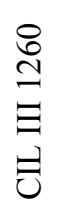 & 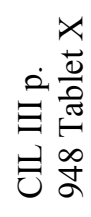 & 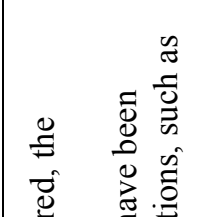 \\
\hline 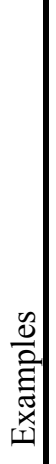 & 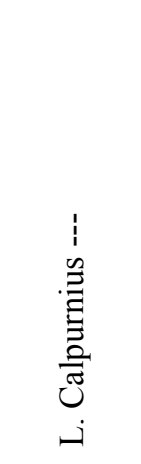 & 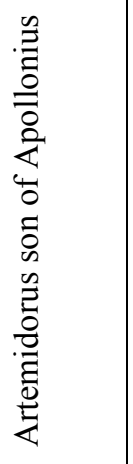 & 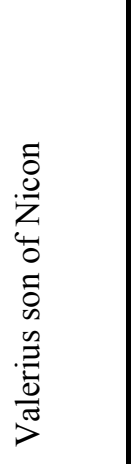 & 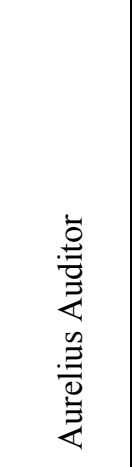 & 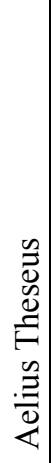 & 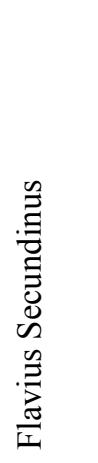 & 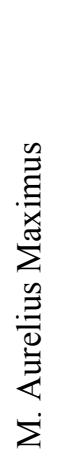 & 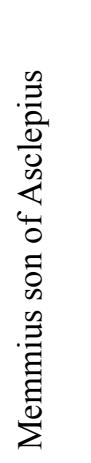 & 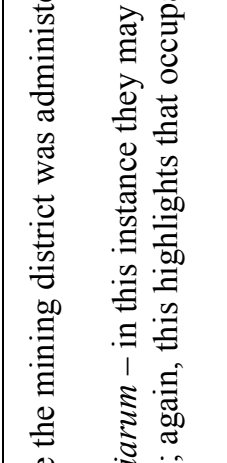 \\
\hline 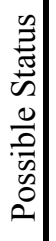 & 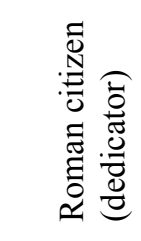 & 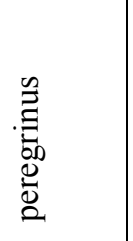 & 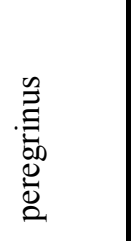 & 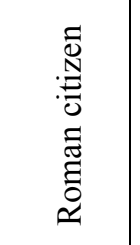 & 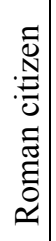 & 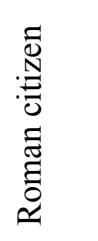 & 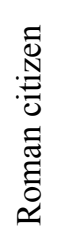 & 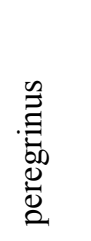 & 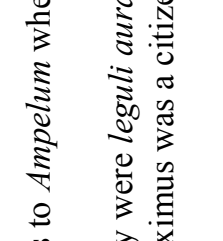 \\
\hline 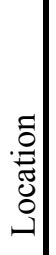 & $\begin{array}{l}\Xi \\
\stackrel{\Xi}{0} \\
\stackrel{\Xi}{Z}\end{array}$ & 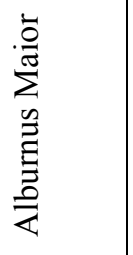 & 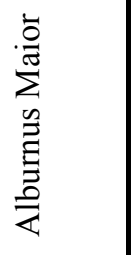 & 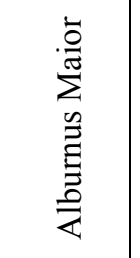 & 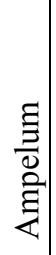 & 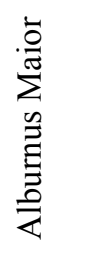 & 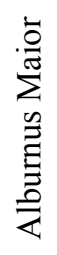 & 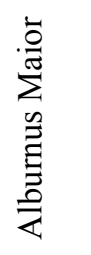 & 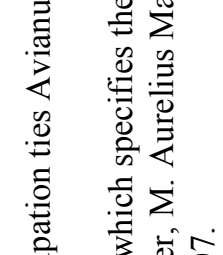 \\
\hline 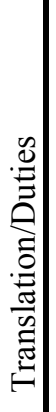 & 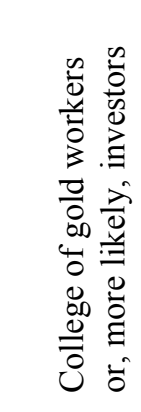 & 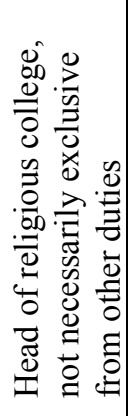 & 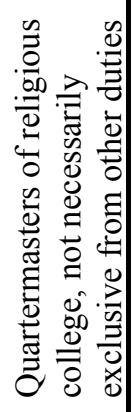 & 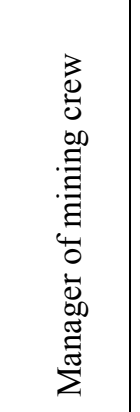 & $\begin{array}{l}\frac{5}{\Xi} \\
\frac{\Xi}{0} \\
\frac{0}{0} \\
0\end{array}$ & 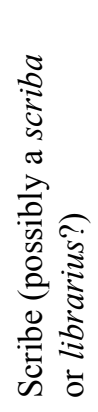 & $\begin{array}{l}\frac{1}{0} \\
\frac{0}{0} \\
0 \\
0 \\
\frac{0}{0} \\
0\end{array}$ & 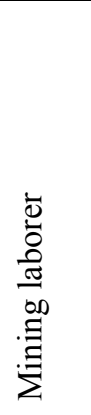 & 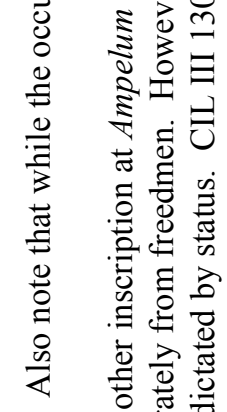 \\
\hline $\begin{array}{l}0 \\
: 0 \\
0 \\
0 \\
0\end{array}$ & 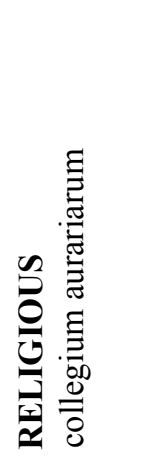 & 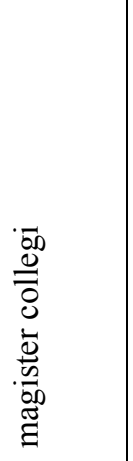 & 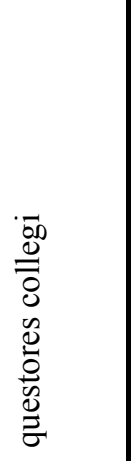 & 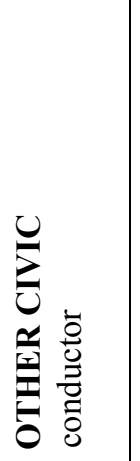 & 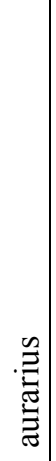 & 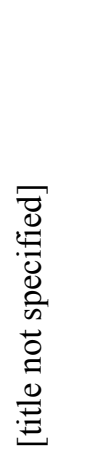 & 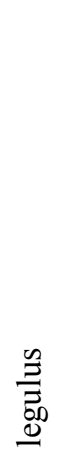 & 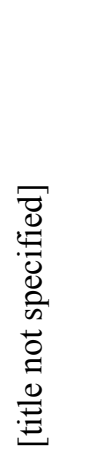 & 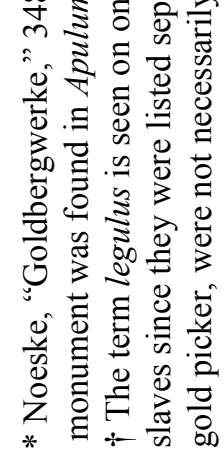 \\
\hline
\end{tabular}




\section{State Identity}

The Roman Empire's use of the local elite to promote Roman laws, the economy, and order is often noted in discussions of provincial histories. ${ }^{278}$ Any coherent expression of Roman identity was communicated through the wealthy and the military, the latter both while on duty and as retired veterans. However, the empire's reach combined with a tolerance for cultural difference created a series of discourses about what made one Roman. The impact of elite "personal interest" on the creation of community norms was a constant variable and the limitations of elite power made their approaches responsive to local conditions. ${ }^{279}$ Even if one had a clear idea of what they perceived as Roman, their economic, social, and regional status could influence their access and expression of these ideas.

In the mining communities this experience of elite influence varied between the state representatives (imperial officials and the military) and local community leaders. Common challenges of the occupation and access to imported goods forged a macro mining culture that incorporated Roman technology, material culture, and ideas. In the larger mining district, miners and conductores recognized their membership in the empire and expressed this inclusion through the worship of state associated cults, the incorporation of Latin, and the use of Roman legal conventions. The degree of involvement by imperial officials versus local leadership in facilitating access to Roman

\footnotetext{
${ }^{278}$ Some recent examples include Clifford Ando's Imperial Ideology and Provincial Loyalty in the Roman Empire (2000), Greg Woolf's Becoming Roman: The Origins of Provincial Civilization in Gaul (1998), J.E. Lendon's Empire of Honour (1997), and Martin Millet's The Romanization of Britain (1990). In Britain, Tacitus famously describes the local elite adopting Roman dress, habits, and language that he equated with servitude to the empire. Tac. Ag. 21.

${ }^{279}$ Sipilä, Reorganization of Provincial Territories, 6-7 and 13-14.
} 
ideas is uncertain. But the combined physical, epigraphic, and written evidence suggests both elite groups played a role in shaping the mining community.

\section{$\underline{\text { State Cults }}$}

There was not a single supreme deity for the mining community at Alburnus Maior. Both state example and local preference created an unofficial pantheon of mining deities that was very similar to the deities found in other imperial mining districts. ${ }^{280}$ Both the Romans and indigenous cultures were polytheistic and evidence suggests there was a hybridization of deity attributes. ${ }^{281}$

The procurator's staff, soldiers, technology experts, merchants, and miners worshiped many deities that ultimately focused on the common goal of a productive mining district. Gods protected the bounty of the earth above, such as the trees necessary for mining and smelting operations, as well as the subsoil filled with precious ores. Gods partially associated with fertility, such as Liber and Libera, Silvanus, Diana, and Terra Mater, had dedications around Alburnus Maior and again in fewer numbers at the administrative center of Ampelum (see Appendix A). Combined, there are twenty altars to these deities at Alburnus Maior which makes up one quarter of the total dedications in the mining community to date. Many of the Roman gods retained the traits they were known for in the Roman pantheon. For example, both Diana and Apollo were popular at Alburnus Maior, likely due to their association with the ores they represented, Diana with

\footnotetext{
${ }^{280}$ Domergue, Les Mines Antiques, 25.

${ }^{281}$ Indigenous deity names are mostly absent in the epigraphic record. Therefore, their beliefs are more apparent in the added or accentuated character traits of Greco-Roman deities. This will be seen more in the discussions of Neptune and Silvanus in the following chapter.
} 
both silver and lead, and Apollo with gold. ${ }^{282}$ Some Roman gods gained local significance related to fertility. For example, dedications found to the divine couple of Liber and Libera are especially common in the Danube provinces where this couple had a special association with fertility which may have been related to an indigenous deity couple adapted to the Roman names. ${ }^{283}$

There were a few gods worshiped at Alburnus Maior that expressed membership in (and allegiance to) the Roman Empire. Terra Mater was not only associated with the fertility of the earth and the dangers present underground but also a patroness to miners and others involved in the metallum. ${ }^{284}$ At mines in Dalmatia, Terra Mater was worshiped by officials in a series of dedications in the Una and Sana Valleys celebrated every April $21^{\text {st }}$ by the conductor and then the procurator. ${ }^{285}$ This date was also Rome's birthday; it marked the founding of Rome in $753 \mathrm{BCE}$, which further supports the connection between this cult and the state. ${ }^{286}$ In Moesia Superior near Mt Kosmaj, state nummi metallorum (mining coins) depicting Terra Mater circulated. ${ }^{287}$ At Alburnus Maior, Terra Mater was worshiped by a possible unnamed collegium and dedicators of

\footnotetext{
${ }^{282}$ Apollo appears in six dedications and Diana in five at Alburnus Maior (see Appendix A). These gods were often associated with these precious metals at other mines and on the coinage directly. Slobodan Dušanić, "The Miner's Cults in Illyricum,” PALLAS 50 (1999): 132.

${ }^{283}$ Damian, Alburnus Maior I, 346-347.

${ }^{284}$ Domergue, Les Mines Antiques, 27 and Dušanić, “Miner's Cults,”132-133.

${ }^{285}$ A total of nine inscriptions were raised between 201-229 CE. Wilkes, Dalmatia, 268. ILJug I 157-159, and 161-162 and ILJug II 778-781.

${ }^{286}$ H.H. Scullard, Festivals and Ceremonies of the Roman Republic (Ithaca, N.Y.: Cornell University Press, 1981) 103-105.

${ }^{287}$ Terra Mater also had a temple in the mining area of Moesia Superior near modern Rudniča. Damian, Alburnus Maior I, 296.
} 
peregrine status. ${ }^{288}$ The cult appears more often closer to mining activity as is seen at other metalla. Unfortunately, the same direct tie to state officials does not exist in the record at Alburnus Maior since the procurator or his staff did not erect dedications at the mines.

A stronger example of association with the state appears in monuments to the imperial family. The imperial cult that was popular in Roman provinces focused on the divine emperor and royal family but largely expressed loyalty to the state than a particular personality. ${ }^{289}$ In the mining district, most dedications were by those connected to the administration. For example, the monument to Commodus in Ampelum was erected by the procurator and another to Septimius Severus by the city council. ${ }^{290} \mathrm{~A}$ dedication from Ampelum ca.167 CE by the collegium aurariarum (college of gold workers) to "Jupiter Optimus Maximus and for the health of the emperor," shows another direct connection between the mining industry and the empire. This monument was erected by L. Calpurnius [---], a member of the collegium who was already a Roman citizen when most miners working at the mines were of peregrine status. This collegium was more likely made up of entrepreneurs or conductores. ${ }^{291}$ A dedication at Alburnus

\footnotetext{
${ }^{288}$ There are two different readings of the dedication placing this connection in some doubt. While the archaeologists read the inclusion of possible ele[(c)?]tis?, the inscription in ILD reads it as part of a proper name Sumeletis. Damian, Alburnus Maior I, 295-296 and ILD 397. The dedications to Terra Mater are more frequent at Alburnus Maior than Ampelum where the two dedications at the administrative center were erected by the same citizen. IDR III/3 330-331 = CIL III 1284-1285.

${ }^{289}$ Clifford Ando, Imperial Ideology and Provincial Loyalty in the Roman Empire (Berkeley: University of California Press, 2000) 40-41.

${ }^{290}$ The full name of the procurator is lost only the cognomen Maximus is clear. CIL III 1306a $=$ IDR III/3 281. The dedication to Lucius Septimius Severus "pro [c]onsul[i] ordo Ampele[nsium]" CIL III $1308=$ IDR III/3 284. Similar examples are found in mining districts of Dalmatia and Moesia Superior. CIL III 8359 and CIL III 6313.

${ }^{291}$ CIL III 941 and Noeske, “Goldbergwerke,” 367.
} 
Maior to Fortuna Augusta by Plator, son of Baotus, indicates cults to the emperor were also practiced by those of peregrine status. ${ }^{292}$

The clearest indication of an imperial cult appears in the dedications to Jupiter Optimus Maximus (I.O.M.). Jupiter, the best and greatest, was a popular deity who represented Rome's power and sovereignty and was often tied to the emperor with dedications like the one by the collegium aurariarum noted above. As the imperial headquarters of the mines, it is not surprising that there was a temple to I.O.M. at Ampelum. ${ }^{293}$ The popularity of I.O.M. at Ampelum is attested by his appearance in 50\% (or 27 of 54) of the dedications (see Appendix A). Most inscriptions to I.O.M. at other imperial mines were by Roman citizens who were often administrative officials and/or imperial freedmen. ${ }^{294}$ At Ampelum this same pattern exists as nineteen of the twentyseven dedications are by citizens. At Alburnus Maior, $20 \%$ of the dedications were to I.O.M. Half were erected by Roman citizens and a majority of these by the acting beneficiarii consularii, legionaries who worked in provincial administration. ${ }^{295}$ Another dedication belongs to M. Aurelius Maximus (enfranchised sometime after $161 \mathrm{CE}$ ), who identifies himself as a legulus which may mean he was a gold picker. ${ }^{296}$ This illustrates again that both citizens and non-citizens worked as miners at Alburnus Maior. It also suggests the I.O.M. cult was not limited to the imperial hierarchy. Nor was this cult

\footnotetext{
${ }^{292}$ ILD 402.

${ }^{293}$ Damian, Alburnus Maior I, 297.

${ }^{294}$ Dedications to I.O.M. were often erected by procuratores, their staff and conductores at imperial mines. Dušanić, "Miner's Cults," 135.

${ }^{295}$ ILD 359, ILD 360, ILD 370, and ILD 373. Also see Appendix B for the full text.

${ }^{296}$ CIL III $1260=$ IDR III/3 390. The only other inscription in Dacia to use legulus is by the leguli aurariarum who dedicated a funerary monument in Ampelum. CIL III 1307 = IDR III/3 283.
} 
limited to citizens as the remaining dedications to I.O.M. belong to miners of peregrine status (see Appendix B). There does seem to be some difference in the quality of altars as those by citizens, especially the beneficiarii consularii, are better carved, more embellished, and average about ten centimeters taller than those by peregrine groups. ${ }^{297}$ Although only one peregrine altar indicates it was erected on behalf of a collegium, it is likely that most of these were dedicated by representatives of a larger group. ${ }^{298}$ These altars to I.O.M. currently outnumber those to any other deity at Alburnus Maior with fourteen to I.O.M. out of eighty-two (the second most popular deity, Silvanus, appears with eleven as seen in Appendix A). Due to this cult's popularity in Ampelum and further examples by beneficiarii consularii near Alburnus Maior, it is likely those raising these monuments were aware of the state affiliation dedications to I.O.M. expressed. This indicates there was an awareness of the Roman Empire and a desire to show affiliation regardless of citizenship status at the mines.

These state cults seem to show a closer adoption of Roman ideas than an adaptation to local beliefs. At this macro level, identity was focused on being part of the Roman Empire and dedicators were determined to fit in with those expectations. On the contrary, when Latin and legal documents were used, they were not so clearly utilized to match Roman expectations.

\footnotetext{
${ }^{297}$ This average was calculated using all the altars but IDR III/3 390 which did not have dimensions listed. The average height for altars by citizens was $81 \mathrm{~cm}$ and those commissioned by peregrini was $72 \mathrm{~cm}$.

${ }^{298}$ collegii Sardiat(a)e ILD 398. Archaeologists and historians argue the poor quality engravings and misspellings indicate many of these altars were engraved by miners. If many were earning salaries similar to Memmius, then they could afford these altars by pooling their funds but did not hire a stone mason to finish the altar - this will be discussed more in Chapter 4 .
} 


\section{Language and Law}

Outside Italy, Latin was an urban language that slowly influenced vernacular languages in rural areas. ${ }^{299}$ Equally remote, mining communities were unique in their connection with both imperial administration and the military, entities noted for their use and spread of literacy. ${ }^{300}$ Additionally, the influx of immigrants into the area required a universal language for communication and cooperation. In the end, although these areas lacked many of the comforts associated with urban life, they were not devoid of the ideas and uses of reading and writing. The Roman presence encouraged the use of Latin and written agreements as seen on the wax tablet contracts.

Although most miners could not write, the written contract was recognized as valuable. Three contracts between miners and conductores illustrate the use of legal documentation to negotiate terms and guarantee pay. ${ }^{301}$ The contract between the miner Memmius, son of Asclepius, and Aurelius Adiutor lists penalties that ultimately seem to favor the conductor. ${ }^{302}$ Only the last part specifies that if there is any delay in the payment of salary to Memmius, then Aurelius Adiutor can also be fined. The creation of the contract is attributed to Memmius who asked the scribe Flavius Secundus to write for him since he did not know how. ${ }^{303}$ However, Memmius did sign his own name on the

\footnotetext{
${ }^{299}$ Moatti, "Translation, Migration and Communication," 111-112.

${ }^{300}$ Ian Haynes, "Military Service and Cultural Identity in the auxilia," in The Roman Army as a Community, eds. Adrian Keith Goldsworthy, Ian Haynes, and C. E. P. Adams (Portsmouth: Journal of Roman Archaeology, 1999) 171.

${ }^{301}$ CIL III pp. 948-949 Tablets IX, X, and XI.

${ }^{302}$ Although wages were not calculated daily for these contracts, it is interesting to note that Memmius's 70 denarii for 180 days of work would have equaled less than 2 sesterces a day. Therefore, the fee of 5 sesterces 8 asses for each day missed was substantially high. See Appendix G for full contract.

303 “se litteras scire negavit.” CIL III p. 948 Tablet X.
} 
document which suggests he did have some education and may have even been able to read the final draft. ${ }^{304}$ Despite his writing ability or knowledge, Memmius found value in paying for a written contract to protect his rights. Additionally, a fourth contract written in Greek charges a conductor for back pay owed to a group of Greek speaking miners. Although in Greek, the contract follows the same format as the Latin contracts and suggests the parties were more interested in being able to understand (possibly read) the contract than introduce a new legal form. ${ }^{305}$ Thus both individuals and groups utilized Roman law to protect their rights.

Participation in forming legal contracts included those of disparate status. The witnesses to many of the contracts were a mixture of men of peregrine status and those with Roman citizenship (see Table 3.2 for examples). This suggests that although they had separate rights under Roman law, they could enter and provide testimony for contracts despite this difference. Usually there were limitations to the legal rights of civitates peregrinae who needed a patron with citizenship to express their rights in legal cases. Elite guarantors are not recorded as instigating the wax tablet contracts on behalf of peregrinae. But some hierarchy is evident. An examination of witnesses for the contracts reveals that a majority were Roman citizens (an asterisk marks witnesses on Table 3.2). When citizens are not involved, higher peregrine officials, such as a princeps or decurio, are evident (see Table 3.2, example 2). Additionally, although Memmius, son

\footnotetext{
${ }^{304}$ Adolf Berger, “A Labor Contract of A.D. 164: CIL, III, P. 948, No. X,” Classical Philology 43, no. 4 (1948): 232.

${ }^{305}$ Note that Tablet IV is in Greek suggesting the workers and the conductor were more comfortable with Greek. Although the whole contract does not remain, it seems to specify a penalty for back pay - twentythree denarii due by Sept $28^{\text {th }}$ or $1 \%$ interest per month as well as an additional twenty-five denarii fine. CILL III p. 933 Tablet IV
} 
of Asclepius, hired the scribe to write the contract between him and the citizen conductor Aurelius Auditor, his two witnesses are also both conductores. ${ }^{306}$ This may suggest some hierarchy was involved and perhaps the completion of contracts was limited by the participation of witnesses of a minimum social status. Miners were not completely marginalized with regard to legal protection but their access to it was limited.

Finally, although conductores, decuriones, and principes appear on the wax tablets, higher officials from the nearby cities were not always involved. The local community leaders, clerks, and officers likely had a greater impact on the use and adaption of Roman legal norms. Although the sources are limited, it is interesting to note that the contracts between conductores and laborers make no mention of the procurator or a submission of the agreement to a records office at Ampelum. Officials and local offices, such as the scribe for Memmius at Immenosus Maior, were likely the primary contacts for the imperial hierarchy (see Table 3.2 for additional contract locations). This does not mean standards set by the procurator were not in place. The three labor contracts all use the same formulaic language and include similar conditions which suggest they followed a standard form. ${ }^{307}$ Additionally, soldiers and veterans are present in some contracts that include witnesses of peregrine status from Alburnus Maior which suggests the soldiers' experience of Roman legal norms was shared with the mining

\footnotetext{
${ }^{306}$ Socratio son of Socratio (Socratio Socrationis) and Titus son of Beusan, called Bradua (Titus Beusantis qui et Bradua) are both listed as conductores in other contracts: CIL III p. 948 Tablet IX and CIL p. 949 Tablet XI respectively.

${ }^{307}$ However, there was some local variation as the contracts are not sectioned into three parts which was a normal Roman legal practice. Theodor Mommsen, ed., CIL III/2 p. 922.
} 
community. ${ }^{308}$ For example, Appius Proclus, who identifies himself as a veteran of the legio XIII Gemina was a witness in a sale of a slave between two peregrinae identified with the mines. ${ }^{309}$

Table 3.2: Contracts and Citizenship Status (*Indicates witness for the contract.) ${ }^{310}$

\begin{tabular}{|c|c|c|c|c|c|}
\hline & Contract & Citizen & Peregrine & Location & Source \\
\hline 1 & $\begin{array}{l}\text { Dissolution } \\
\text { of a } \\
\text { Collegium } \\
\text { in } 167 \mathrm{CE}\end{array}$ & $\begin{array}{l}\text { L. Vasidius Victor* } \\
\text { C. Secundinius Legitimus* } \\
\text { Ulpius Felix* } \\
\text { Stertinius Rusticus* } \\
\text { Aelius Plator* }\end{array}$ & $\begin{array}{l}\text { Artemidorus Apolloni } \\
\text { Offas Menofili } \\
\text { Valerius Niconis } \\
\text { Julius Juili } \\
\text { Septemboris Platoris* }\end{array}$ & $\begin{array}{l}\text { Resculum } \\
\text { (near } \\
\text { Alburnus } \\
\text { Maior) }\end{array}$ & $\begin{array}{l}\text { CIL III } \\
\text { p. } 925 \\
\text { Tablet I }\end{array}$ \\
\hline 2 & $\begin{array}{l}\text { Loan of } \\
140 \text { denarii } \\
\text { in } 162 \mathrm{CE}\end{array}$ & $\begin{array}{l}\text { Julius Alexander (borrower) } \\
\text { Iulius Maximus* } \\
\text { Aurelius S---* }\end{array}$ & $\begin{array}{l}\text { Anduenna Batonis } \\
\text { (lender) }\end{array}$ & $\begin{array}{l}\text { Deusara (near } \\
\text { Alburnus } \\
\text { Maior) }\end{array}$ & $\begin{array}{l}\text { CIL III } \\
\text { p. } 931 \\
\text { Tablet III }\end{array}$ \\
\hline 3 & $\begin{array}{l}\text { Purchase of } \\
\text { a } 6 \text { year old } \\
\text { girl in } 139 \\
\text { CE }\end{array}$ & & $\begin{array}{l}\text { Maximus Batonis } \\
\text { Dasius Verzonis } \\
\text { Maximus Veneti* } \\
\text { (princeps) } \\
\text { Masurius Messii* } \\
\text { (decurio) } \\
\text { Anneses Andunocnetis* } \\
\text { Planius Verzonis* } \\
\text { Liccaius Epicadi* } \\
\text { Epicadus Plarentis* }\end{array}$ & $\begin{array}{l}\text { Kartum (near } \\
\text { Alburnus } \\
\text { Maior) }\end{array}$ & $\begin{array}{l}\text { CIL III } \\
\text { pp. 937-9 } \\
\text { Tablet VI }\end{array}$ \\
\hline 4 & $\begin{array}{l}\text { Purchase of } \\
\text { a Greek } \\
\text { boy in } 142 \\
\text { CE }\end{array}$ & $\begin{array}{l}\text { Appius Proclus (veterani } \\
\text { legionis XIII geminae)* } \\
\text { Antonius Celer* } \\
\text { Iulius Viator* } \\
\text { Ulpius Severinus* } \\
\text { L. Firmius Primitivus* }\end{array}$ & $\begin{array}{l}\text { Dassius Breucus } \\
\text { Bellicus Alexandri }\end{array}$ & $\begin{array}{l}\text { Canabae } \\
\text { Legionis XIII } \\
\text { Gemina } \\
\text { (Apulum) }\end{array}$ & $\begin{array}{l}\text { CIL III } \\
\text { pp. } 941-3 \\
\text { Tablet } \\
\text { VII }\end{array}$ \\
\hline 5 & $\begin{array}{l}\text { Purchase of } \\
\text { half a } \\
\text { house in } \\
159 \mathrm{CE}\end{array}$ & $\begin{array}{l}\text { L. Vasidius Victor* } \\
\text { T. Flavius Felix* } \\
\text { M. Lucanius Melior* } \\
\text { T. Aurelius Priscus* }\end{array}$ & $\begin{array}{l}\text { Andueia Batonis } \\
\text { Veturius Valens } \\
\text { Plator Carpi* } \\
\text { Bato Annaei* } \\
\end{array}$ & $\begin{array}{l}\text { Alburnus } \\
\text { Maior }\end{array}$ & $\begin{array}{l}\text { CIL III } \\
\text { p. } 945-7 \\
\text { Tablet } \\
\text { VIII }\end{array}$ \\
\hline 6 & $\begin{array}{l}\text { Contract } \\
\text { for labor in } \\
164 \mathrm{CE}\end{array}$ & $\begin{array}{l}\text { Flavius Secundinus (scribe) } \\
\text { Aurelius Adiutor } \\
\text { (conductor) } \\
\text { Titus Beusantis qui et } \\
\text { Bradua (conductor)* }\end{array}$ & $\begin{array}{l}\text { Memmius Asclepi } \\
\text { Socratio Socrationis } \\
\text { (conductor)* }\end{array}$ & $\begin{array}{l}\text { Immenosus } \\
\text { Maior (near } \\
\text { Alburnus } \\
\text { Maior) }\end{array}$ & $\begin{array}{l}\text { CIL III } \\
\text { p. } 948 \\
\text { Tablet X }\end{array}$ \\
\hline
\end{tabular}

\footnotetext{
${ }^{308}$ V. Moga, "Les détachements de la XIIIe légion Gemina en Dacie," in Apulum X: Arheologie-IstorieEtnografie in Memoriam Avram Iancu: 1872 - 1972 (Alba Iulia: Muzeul de Istorie, 1972) 152 and CIL III pp. 941-943 Tablet VII and p. 959 Tablet XXV.

${ }^{309}$ CIL III pp. 941-943 Tablet VII.

${ }^{310}$ For further discussion on citizenship, see Noeske, “Goldbergwerke," 386-396.
} 
The level of education of the miners varied. While some miners were literate enough to scratch their name on their lamp or sign their name, others may have completed some of the engravings on altars themselves. ${ }^{311}$ Inscriptions show the influence of handwriting and are often full of mistakes in grammar, order, and letter forms suggesting an incomplete education. ${ }^{312}$ Most of the monuments were raised by representatives of local collegia. Since they were expected to oversee the dedications for the community they may have been literate. There is variation in the execution of inscriptions and some of the more expensive and correctly inscribed monuments were erected by those directly associated with administration, such as the beneficiarii consularii. ${ }^{313}$ The administration may have encouraged (or at least allowed) access to education. In the lex Metalli Vipascensis, school teachers were granted a tax exempt status from the procurator and there is evidence of a Greek instructor in the mining region of Komaj in Moesia Superior. ${ }^{314}$ Evidence for a teacher at Alburnus Maior has not been found but archaeologists are certain some of the monuments were inscribed by miners. Finally, an increase in the use of Latin names by peregrine miners such as

\footnotetext{
${ }^{311}$ For example the cursive Latin inscriptions on the lamps found at Carnic $-I V S \lambda V C$ and $A B$. Damian, Alburnus Maior I, 482.

${ }^{312}$ In the thirty-five inscriptions found on Hăbad Hill only nine are engraved correctly. Damian, Alburnus Maior I, 152-153. The epigraphic data from Moesia Superior provides a similar example where some of the mistakes are bad enough to make the inscription illegible which may suggest the visual use of inscriptions may have been more important than the actual meaning in some instances. Mócsy, Pannonia and Upper Moesia, 216-217.

${ }^{313}$ Damian, Alburnus Maior I, 153.

${ }^{314}$ ILS 6891 and IMS I 150.
} 
Seneca, son of Biso, suggests the use of the language increased over time and may have been influenced by fashion, affiliation, or both. ${ }^{315}$

Indigenous vernaculars, such as Illyrian, Celtic, Dacian, and Thracian languages, were likely used at individual settlements near Alburnus Maior, but public dedications and official documents were limited to Latin or, more rarely, Greek. Some inscriptions are in Greek and one of the wax tablet contracts was written in Greek. Evidence from Domavia in northeast Dalmatia indicates that Greek was the universal language used at the silver mines and some immigrants to Dacia may have learned their Greek in the western Balkans (see Regional Map in Appendix D). ${ }^{316}$ The presence of Greeks in Dacia is well attested in urban centers where they made up as much as $1 / 5$ of the population. ${ }^{317}$ At Alburnus Maior only six religious dedications were inscribed in Greek and another three might be Latinized forms of Greek deities (see Appendix A). ${ }^{318}$ The names on these monuments also show peregrine dedicators and testify to the presence of local Greek collegia but at Alburnus Maior they were a minority. ${ }^{319}$

\footnotetext{
${ }^{315}$ Both Latin and Greek peregrine names were influenced by background and education. Rada Varga, "The Peregrine Names from Dacia," Acta Musei Napocensis 43-44, no. 1 (2008): 240. Seneca Bisonis AE (1944) $24=$ IDR III/3 388.

${ }^{316}$ Ante Škegro, "The Economy of Roman Dalmatia," in Dalmatia: Research in the Roman Province 1970-2001: Papers in Honour of J.J. Wilkes, eds. David Davison et al. (Oxford: Archaeopress, 2006) 150.

${ }^{317}$ Haynes and Hanson, "Roman Dacia,"21.

${ }^{318}$ Apollo Piruniinus does not have a direct Greek connection but a Latinized version of $\pi \varepsilon \rho \circ \eta \eta$ may refer to Apollo's piercing bow. Damian, Alburnus Maior I, 300 and ILD 400. The other two Latinized names are Maelantonius ILD 363 and Naoni ILD 372.

${ }^{319}$ The two Latinized dedications (Maelantonius and Naoni) have Illyrian elements to their names and two

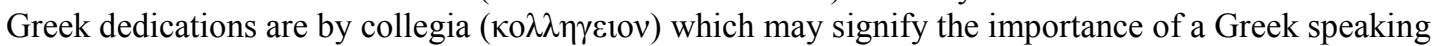
religious group for one of the local communities (see Appendix A). It is possible those with Greek names were slaves as it is uncertain if the use of genitive was an adoption of local peregrine custom or a retention of traditional naming conventions in other areas of the empire. IDR III/3 399 (also in Appendix A). The peregrine use of genitive to show familial ties rather than slave status is discussed in Chapter 5 .
} 
The mining community adopted Latin as the preferred common language for inscriptions and documents but their knowledge was often incomplete. Nonetheless, the incorporation of the written word to make public dedications and legal agreements expressed an added level of adaptation to Roman ideas. From religious cult to legal rights, Latin became a way of participating locally and established a continued association within the empire.

\section{Conclusions}

Civic and military administration maintained the presence of the Roman Empire through hierarchal structures and legal formalities. State officials encouraged early colonization and elite investments aided this effort and continued the process. The administrators controlled economic activity and supplied the miners to keep them in place. These efforts provided access to goods from nearby cities that would not have reached this rural community consistently on its own. Unlike most rural communities, at Alburnus Maior the administrative policies influenced daily life and maintained an awareness of the Roman Empire. Responding to these influences, some members of the mining community chose to express their membership in the Roman Empire through state cults. Additionally, the incorporation of legal documents followed Roman conventions with few alterations. Some miners found value in these contracts and were likely encouraged by examples from members of the local elite who promoted new ways for protecting business and personal interests. Citizenship status did not affect contracts but the presence of higher status witnesses may indicate some discrepant access wherein miners were still required to have someone of rank participate. Finally, Latin provided a common language for these colonists as they created a new community. Nonetheless, 
these immigrants still gravitated to separate community identities and formed their own distinct settlements. These group identities permeated daily life and became central to public participation in the mining community. The state administration and public regulation outlined above influenced the entire mining district, but it was through group membership that miners negotiated their local identities. 


\section{Chapter 4: Community Identity at Alburnus Maior}

The development of mining communities under Roman occupation is often examined using the concept of Romanization, which inherently measures the level of attained "Romanness" or their resistance to assimilation in the communities. When historians and archaeologists look at identity, it becomes easy to focus on expressions of polarity, as projections of identity generally "create rather than reduce social

distance. ${ }^{320}$ Especially in high immigrant communities, like mining districts, there was a strain on identities as groups and individuals faced everything from new languages to disruption of everyday living and expectations. This could trigger a focus on differences that both amplified and created social identities. At Alburnus Maior, settlements were separated by origin or tribal identity in a partial response to this social stress.

Mining settlements and their activities became the focal point of local group identity and membership, which distinguished one in the larger mining community. These local affiliations supported miners as they faced the challenges of the mining industry. The mines retained immediacy in daily life as the domestic and public spaces of the miners were built near exploitation sites. All miners, and likely many specialists and conductores, experienced some level of the physical impact from the mining environment. Additionally, inherent dangers in mining directed policy that encouraged disparate immigrant groups to work together and influenced religious responses for protection.

As is seen in the development of state identity, a larger mining community emerged at Alburnus Maior despite cultural differences. The smaller mining settlements

${ }^{320}$ Mattingly, “Cultural Crossovers,” 289. 
and collegia created another layer of group identity within this larger community. The ideas used to construct local communities and the purpose of these settlements is examined first. The mining experience is then evaluated for its influence on daily life and religious response. Finally, the prevalence of community worship provides another example of the importance of group identity in forging local ties and communicating status at Alburnus Maior.

\section{Constructing Community}

The community around Alburnus Maior is better understood as a district with a web of small settlements which were connected by their adherence to the same standards of production set by the procurator. The functions at the center, the namesake Alburnus Maior, is uncertain and any official or domestic buildings are now gone. Instead the smaller settlements provide the story of community development. Alburnus Maior was surrounded by seven massifs, or mountain points, and evidence of Roman works stretch 13,600 square meters. ${ }^{321}$ Mining settlements did not concentrate in the valley but dotted the slopes, often placed close to surface exploration sites and gallery entries. The map of Alburnus Maior in Appendix E shows a few examples of these settlements arranged in the mining community. At least twenty-one of these small settlements have been identified to date. ${ }^{322}$ These settlements were not permanent fixtures and there was some movement related to efficiency and environment. Additionally, mining access was not the sole consideration for the establishment of settlements as some were not located close to mineral exploration. It is possible these communities performed other surface

\footnotetext{
${ }^{321}$ The seven massifs are Cârnic, Cârnicel, Cetate, Coş, Orlea, Ţarina and Carpeni. Baron, "Lead isotope," 1093.

322 Damian, Alburnus Maior I, 82 and 27. Oltean, Dacia, 151.
} 
activities or worked at other sites. ${ }^{323}$ While the necessities of the mining industry influenced settlement foundations, these requirements were not the only driving force in creating these communities.

The two types of communities established around Alburnus Maior were vici and kastella. $^{324}$ Vici (villages) and kastella (generally translated as fort) were both civil settlements at Alburnus Maior and likely had some form of local leadership. ${ }^{325}$ It is uncertain if there were different legal rights given to these communities by the imperial procurator or if they worked together as districts coordinated through central representation at Alburnus Maior. ${ }^{326}$ The procurator or his staff likely assigned groups space based on their immigrant identity in the early development of the mines. Vici and kastella used tribal and regional names that appear to have correlated with their origin. These settlement names, established in the early second century, often became part of a miner's social identification at Alburnus Maior. The use of community names is evident by $139 \mathrm{CE}$ in the wax tablet contracts. For some, it became part of their personal identity that they used in both documents and inscriptions. For example, in the documentation of a slave trade, Dasius, son of Verzon, includes that he is from Kavieretium (a possible

\footnotetext{
${ }^{323}$ For example, at the Balea Site on the Carpeni massif, later drainage work cut through older dwellings. Damian, Alburnus Maior I, 385 and 289.

${ }^{324}$ Castellum is spelled with a ' $\mathrm{k}$ ' because this is how it appears in the epigraphic record around Alburnus Maior. Both of these settlements are attested in inscriptions and the wax tablets.

${ }^{325}$ Although kastella are often translated as forts it should be noted these were civic and not military communities. Archaeologists would not have used the name but for the epigraphic evidence using this term. Dušanić, "Late Roman Mining in Illyricum," 249 ftnt 5.

${ }^{326}$ It is believed the vici and kastella in Dalmatia acted as their own administrative units which is sometimes referred to as the "Dalmatic System". The higher population of Illyrian-Dalmatian settlers may suggest a similar system was set up around Alburnus Maior. Damian, Alburnus Maior I, 81-82.
} 
vicus) as part of his identification throughout the text. ${ }^{327}$ Not every miner used this type of identification and it is unlikely it was required by law. Instead, the settlement names were part of local group identity that distinguished miners in the larger mining community.

The names used by these immigrants suggest that different experiences of empire influenced how groups identified their origin. Some settlements used an urban center from their originating province such as the kastellum Ansis associated with those from Ansium, Dalmatia or kastellum Baridustarum with immigrants from Bariduum, Dalmatia. $^{328}$ Both of these communities were in the Liburnia region, which was conquered early and experienced faster urban development (see Regional Map in Appendix D). Settlers from these areas likely adopted the urban centers as representative for their group identity, but they were not citizens of the municipia as is evident in their civitas peregrina status. $^{329}$ Thus, these names may have also been tribal. But the Roman establishment of conventus (judicial assizes) often encouraged peregrine governance through the tribal elite. ${ }^{330}$ Their representatives were required to conduct legal business in town which forged a connection between the conventus and urban communities. In some instances the settlements at Alburnus Maior were associated with tribal names such

\footnotetext{
${ }^{327}$ CIL III pp. 937-939 Tablet VI. Historian V. Wollmann suggested that due to the scant early epigraphic record the initial immigrants to the region had assimilated with the native population and only later created these separate communities. However, this is unlikely due to the scale of immigration and this lack of early epigraphic evidence may have more to do with the origin of colonists and their experience of conquest by the Roman Empire. Baron "Lead isotope," 1093.

${ }^{328}$ A few of these settlements were located by comparing the epigraphic and archaeological record. For example, the kastellum Ansis has been identified with the Hăbad site on the Cetate massif. Damian, Alburnus Maior I, 127, 156 and 383. See the Map of Alburnus Maior in Appendix E.

${ }^{329}$ Damian, Alburnus Maior I, 156.

${ }^{330}$ Wilkes, Illyrians, 213. Pliny $N H 3.25$.
} 
as the vicus Pirustarum settled by the Pirustae and two settlements also named after Dalmatian tribes, Maniates and Sardeates. ${ }^{331}$ Tribal association was also added to the place name. The name Delmatae kastello Starvae identified that members of the Delmatae tribe were settled at kastellum Starva. ${ }^{332}$ For some groups, this tribal identity was more important than urban place names in their home region of Dalmatia. Both the Pirustae and the Delmatae partially developed their tribal identity in opposition to Roman expansion and experienced violent conquest which included the breaking apart of the tribes and marginalization of their own elite. ${ }^{333}$ This tribal association was retained into the third century. After the Marcomannic Wars, the funerary monument for T. Aurelius Aper, a princeps at Ampelum, notes that he was assigned as leader to the Delmatae from Splonum, another mining center in Dalmatia. ${ }^{334}$ The princeps was interested in showing both urban and tribal affiliation.

\footnotetext{
${ }^{331}$ Damian, Alburnus Maior I, 291.

${ }^{332}$ While not all communities have been found, this one was likely on the Trarina massif C. Ciongradi, A. Timofan and V. Bârcă, "Eine neue Erwähnung des kastellum Starva in einer Inschrift aus Alburnus Maior. Studium zu Epigraphisch bezeugten kastella und vici im Dakischen Goldbergwerksgebiet," Zeitschrift für Papyrologie und Epigraphik 165 (2008): 249-250.
}

\footnotetext{
333 Although they already had a tribal identity, both tribes had conflicts with Rome in the first century BCE as aggressors against Roman allies and both also participated in the Pannonian Revolt of 6-9 CE. The Pirustae were split into three or more groups near Narona and reputedly lived in mountainous regions which were difficult for the Romans to control. The Delmatae were likewise split and denied early native representation in governance. J.J. Wilkes, "The Population of Roman Dalmatia," in Aufstieg und Niedergang der Romischen Welt 2, no. 6, eds. Hidegard Temporini, Sechster Band, and Wolfgang Haase (Berlin: Walter de Gruyter, 1977) 762-763 and 765; Wilkes, Dalmatia, 173-174 and Illyrians, 196-197.

${ }^{334}$ By the time he was assigned the position, T. Aurelius Aper was also a Roman citizen. Volker Wollmann, "Nouvelles Donnees Concernant la Structure socio-ethnique de la zone minere de la Dacia Superior," in Minería y metalurgia en las antiguas civilizaciones mediterráneas y europeas, ed. Claude Domergue (Madrid: Ministerio de Cultura, 1989) 113. "Delmata princ(eps) adsignato (sic!) ex m(unicipio) Splono" CIL III $1322=$ IDR III/3 345. The first groups were also moved under the coordination of a local leader including principes and/or conductores. Principes also appear on the wax tablets which all date before the Marcomannic Wars. Damian, Alburnus Maior I, 290.
} 
This raises an interesting question for the Dacian named communities at Alburnus Maior which appear on the wax tablet contracts. Although archaeological evidence suggests Dacians continued working at the mines after conquest, a connection between the material found at the Carnic massif and the four place names found on the tablets, Resculum, Deusara, Kartum, and Immenosus, does not exist. ${ }^{335}$ Additionally, the use of Dacian place names instead of a tribal identity counters what is seen among Dacians resettled outside the province where the designation of the natione Dacus is the most frequent identifier found epigraphically. ${ }^{336}$ The pressures of a multicultural mining community might be expected to create the same expression of identity. Perhaps these communities did not feel this pressure or the names were used by mixed migrant communities who adopted something local - indeed, Alburnus is also a Dacian name. This latter co-settlement increasingly happened as occupation continued. Since three of these place names appear after $160 \mathrm{CE}$, they may reflect this change. The wide variety in burial practices near settlements around Alburnus Maior further indicates that by the end of the second century most vici and kastella were no longer ethnically homogeneous. Instead, settlement names increasingly represented a local group identity within the mining community. ${ }^{337}$

At these vici and kastella, domestic space was dictated by the environment, realities of the industry, and materials available. Most rural settlements were below 400 meters in Dacia. The mining communities were an exception situated in mountains that

\footnotetext{
${ }^{335}$ Unfortunately, Dacian names do not appear in the epigraphic record at Alburnus Maior. Ciongradi, "kastellum Starva," 253 and 255.

${ }^{336}$ Oltean, "Dacian Ethnic Identity," 98.

${ }^{337}$ Damian, Alburnus Maior I, 290.
} 
reached as high as 800-1200 meters (see Elevation Map in Appendix F). ${ }^{338}$ Houses were placed above mining activities and oriented east-west to allow for more sunlight and warmth. ${ }^{339}$ There were only a few dwellings with hypocaust systems which were likely for administrative staff or conductores. Their construction often involved the legio XIII Gemina who built with more brick and stone and followed Roman architectural forms. ${ }^{340}$ The dwellings for the miners were wooden structures which were partially sunken into the ground when possible; a common pre-Roman building technique in the rural areas of Dacia and the other Danube provinces. ${ }^{341}$ When stone walls were added, clay mortar was used, which was not common for Roman construction but consistent with other mountainous communities. ${ }^{342}$ These popular building techniques were more indicative of mountain living and were not associated with a particular group like the Delmatae or Pirustae. A few unique styles of construction appear at some sites. For example, the floors made of clay and river stone at Tăul Țapului and Hop-Botar sites are associated with colonists from Noricum and Pannonia where this construction was also popular. ${ }^{343}$

\footnotetext{
338 Oltean, "Rural Settlement," 161 and Oltean, Dacia, 28.

${ }^{339}$ Similar orientation has been noted at other mountain communities in Moesia Superior. Damian, Alburnus Maior I, 91.

${ }^{340}$ Noeske noted that rooms for management and records would be in larger complexes. Noeske, "Goldbergwerke," 289. Although most administration was focused in Ampelum, the recorded location for Memmius's contract done at Immenosus Maior was likely one of the small settlements near Alburnus Maior. CIL III p. 948 Tablet X. Evidence of the XIII Gemina involved in the construction of the hypocaust at Carpeni Hill is taken from their stamped bricks. Țentea, "Legion XIII Gemina," 254-255. Hypocausts at the Bisericuță and Tomuş sites show evidence of upkeep and the use of lime mortar and plasters (opus signium) not used on most of the other buildings. Damian, Alburnus Maior I, 429-431 and 444-446.

${ }^{341}$ Oltean, Dacia, 66.

${ }^{342}$ Some of the recent excavated sites showing these techniques are at the Balea site on Carpeni massif and the Găuri site west of the Cetate massif. Damian, Alburnus Maior I, 45-48, 51, 90, 388-390.

${ }^{343}$ Damian, Alburnus Maior I, 91. This is further linked at Tăul Țapului which has been tentatively associated with kastellum Baridustarum from the Liburnia area with a culture considered more Celtic than Illyrian. Wilkes, Dalmatia, 161.
} 
Communal space was predominant in these mining settlements. Rectangular buildings were sectioned into rooms that shared a courtyard. Common areas usually had votive altars raised in a courtyard or niche. ${ }^{344}$ These altars were generally raised by the settlement. For example, the altar to Ianus Geminus in the courtyard at the Găuri site was raised by Aelius, son of Baebius and Beus, son of Plator who were likely representatives for the kastellum. ${ }^{345}$ Large cooking vessels and the presence of a few grinders suggest cooking activity and meals were often shared. ${ }^{346}$ As will be discussed more below, the collegia at Alburnus Maior focused on settlements rather than occupations. Having communal meals as members of collegia was common and perhaps due to limited space or a further alteration of Roman ideas, the feasts were held in domestic spaces as religious and community membership were sometimes one in the same. ${ }^{347}$ This contrasts with the pre-conquest Dacian pattern where rural homes were focused around nuclear family units instead of extended families or communal living within the same structure. ${ }^{348}$ Miners had a room or part of room which they could purchase or possibly rent. For example, in $159 \mathrm{CE}$ Andueia, son of Bato, purchased half a house with a

\footnotetext{
${ }^{344}$ Again, recent examples are at the Găuri, Hăbad and Carpeni massif sites. Damian, Alburnus Maior I, 35-36 and 50.

${ }^{345}$ Damian, Alburnus Maior I, 50-51 and CIL III $7824=$ IDR III/3 389.

${ }^{346}$ The communal "kitchen" with the larger cooking vessels was located at the Hop-Botar site and grinders at different areas. Some of these grinders may have been used in processing ore, but others were used for their domestic function. Damian, Alburnus Maior I, 88-89.

${ }^{347}$ Ramsay MacMullen, Roman Social Relations, 50 B.C. to A.D. 284 (New Haven: Yale University Press, 1974) $77-78$.

${ }^{348}$ Oltean, Dacia, 117.
} 
window from Veturius Valens for 300 denarii in the vicus Pirustarum at Alburnus Maior. $^{349}$

The domestic sites excavated to date are associated with immigrant communities who shared both settlement name and personal space. These mining settlements and spaces solidified local group identities for miners in their new community. However, the realities of the industry encouraged larger group awareness for success and safety in mining. Miners lived in the immediate vicinity of the mines or related industry and their daily experience was shaped by the mining environment.

\section{The Mining Experience}

The physical experience of the mining industry permeated daily labor and life. Therefore, understanding the conditions miners faced illuminates aspects of identity such as their decisions to raise altars or whom they worshiped. Since these actions were usually done by settlements, the mining cults bridged the individual settlements with the aims and beliefs in the larger mining community. Their collective experience was reflected in the popularity of specific deities in the region that spoke directly to local concerns for health, protection, and preservation. This religious identity was directly influenced by the working and living conditions at the mines.

Gold and silver was exploited through surface and underground mining with an efficiency that highlights the organization, communication, and mineral knowledge used in the operations. Surface, or opencast mining, involved working softer stone from deposits found on the surface, usually resulting in open air pits. Underground gallery

\footnotetext{
${ }^{349}$ CIL III pp. 945-947 Tablet VIII. Note this is over two years pay if the miner was paid the seventy denarii for six months like Memmius, son of Asclepius.
} 
mining was either started directly into the mountain face or the result of following a vein of ore discovered in a surface pit. At many sites near Alburnus Maior, such as the Cetate and Cârnic massifs, a combination of both surface and gallery mining coexisted. ${ }^{350}$ This coordinated effort utilized surface exploration to search for new deposits while galleries exploited rich veins of ore underground. ${ }^{351}$ Archaeologists have noted a high level of organization not only between surface and underground works but also between the galleries. Miners communicated their location and were able to unite tunnels skillfully. They exploited veins and broken breccias of ore with such precision as to minimize needless mining or rock waste. ${ }^{352}$ To ensure this efficiency, some ore was processed underground. In a chamber in the Cârnic massif archaeologists found what appears to be a testing area where ores were washed and examined. ${ }^{353}$ This coordination ensured the best use of resources and labor.

Mining was grueling work which was undertaken with iron tools and fire. A miner may have owned his own protective gear such as a hat to protect his head, thick soled shoes, and a pair of knee pads. ${ }^{354}$ Depending on the season or the depth of the mine, the temperature increased and the miner often worked in a loin cloth or naked.

\footnotetext{
${ }^{350}$ Damian, Alburnus Maior I, 199 and 472-3.

${ }^{351}$ Archaeologists classified two strategies used at Alburnus Maior - exploration works which were predominantly surface operations that might include short drifts (horizontal adits) into the mountain and exploitation works which were extensive long galleries that followed the ores deep in the mountains. Damian, Alburnus Maior I, 496.

${ }^{352}$ Damian, Alburnus Maior I, 495. There is evidence of some galleries being pursued with the purpose of connecting different areas of the mine rather than solely following a vein or deposit. At Alburnus Maior, one of these connecting works was 70 meters (230 ft) long. Domergue, Les Mines Antiques, 69.

${ }^{353}$ A wooden pan, found in situ was likely used in this process. Domergue, Les Mines Antiques, 120.

${ }^{354}$ These items have not been found in Dacia but have been recovered in the Spanish mines where leather and hemp products have survived. Thompson, Greek and Roman Slavery, 165.
} 
Any controlled fire setting in the galleries made the temperature and air quality poor while limited ventilation was provided through shafts. ${ }^{355}$ The Romans used lamps to check for "strong vapors" when digging and if the oxygen dropped below $15 \%$ the oil lamps would extinguish. ${ }^{356}$ Poor lighting was provided at Alburnus Maior by a small oil lamp placed on a niche carved in the rock above each miner as they worked. Nystagmus, an eye condition caused by poor lighting attested in the modern mining profession, likely caused blindness and decreased coordination for ancient miners as well. ${ }^{357}$

Fire setting was a common practice in ancient mining which aided in breaking down harder stone both on the surface and underground. These fires could be fed to last for hours as attested in the sixteenth century pre-industrial source De re metallica by Georgius Agricola. ${ }^{358}$ Recent attempts to recreate the process in surface pits resulted in successfully charred stone that flaked more easily. ${ }^{359}$ At Alburnus Maior, evidence of fire setting underground has been successfully carbon dated between the second and fourth centuries $\mathrm{CE}$ where both galleries and large underground chambers or halls were worked by charring. ${ }^{360}$ Fire setting did not always work and there is evidence that some

\footnotetext{
${ }^{355}$ The air quality and conditions changed with the season with spring and fall creating the most stagnant air. R. Shepherd, Ancient Mining (London: Elsevier Applied Science, 1993) 30-31 and 34.

${ }^{356}$ The use of lamps to check for oxygen is noted in Vitruvius's description of digging wells where a lamp was lowered to see if the flame was put out $a$ vi vaporis. If the lamp extinguished then shafts were built. Vitr. De arch. 8.6.13. The oxygen percentage is taken from modern measurements. Shepherd, Ancient Mining, 31.

${ }^{357}$ Shepherd, Ancient Mining, 40.

${ }^{358}$ Georgius Agricola, De Re Metallica (1556), 119-121.

${ }^{359}$ To quench the fire, the Romans believed vinegar would create a more brittle surface than dousing the flames with water. Vitr. De arch. 8.3.19. However, it seems that water was more commonly used and recent experiments of the process have shown that the duration of the exposure to fire had more impact than how it was extinguished. P.T. Craddock, Early Metal Mining and Production (Washington, D.C.: Smithsonian Institution Press, 1995) 34-35.

${ }^{360}$ Damian, Alburnus Maior I, 474-475 and 480.
} 
harder rock did block and redirect underground tunnels. ${ }^{361}$ Controlling the fires

underground and the impact on air quality undoubtedly added to the miner's subterranean

toil.

The conditions above ground also impacted the miners' environment and health. As mentioned above, some miners worked in open exploratory pits, searching for new veins of precious metals. Although lumps of ore were partially sorted below, as attested by the waste piles underground, most of the ores were processed above ground. Pieces were possibly shuttled up by young boys. Youths were noted performing this task at the mines in Egypt by Diodorus Siculus and evidence of their employment at the Dacian mines is attested in the wax tablet labor contract for Memmius and his children. ${ }^{362}$ Pieces were then further divided, washed, broken and ground. This was likely performed by women, old men (those over thirty), and more youths living at the mines. Women were often observed sorting at the mines in other areas of the empire. ${ }^{363}$ Only at quarries, where there were fewer smaller tasks, are children and women not observed at the

\footnotetext{
${ }^{361}$ Evidence was found in the Cârnic massif specifically where silicificated rock was encountered. Damian, Alburnus Maior I, 481-482.

${ }^{362}$ Diod. Sic. 3.13.1. CIL III p. 948 Tablet X.

${ }^{363}$ Diodorus Siculus's account of the mines at Egypt provides a description of women and older men at work. Diod. Sic. 3.13.1-2. This involvement of women, old men, and children in surface sorting and grinding is attested in the fifteenth century account as well and includes illustrations of women working at long wooden sorting tables. Agricola, De re metallica, 269. In the modern age, women and children participate in sorting and processing at the mines at Ishiagu in southern Nigeria. Craddock, Mining and Production, 162. Although it is plausible that women participated in this work at Alburnus Maior, they do not appear in any of the contracts for this purpose. This will be discussed more in Chapter 5 .
} 
extraction sites. $^{364}$ The mineral was then crushed to the size of millet using stone grinders moved by hand. ${ }^{365}$

This crushed ore was then smelted but only a few smelting hearths have been found at Alburnus Maior. Some have suggested the majority of the work was done near Ampelum. ${ }^{366}$ But a litharge roll of lead, used in the process of extracting the silver and gold from the ore, was found at the Cârnic massif and indicates more smelting did take place at Alburnus Maior. ${ }^{367}$ This smelting process released toxins into the environment and long term exposure weakened bones and caused anemia, muscular wasting, and abdominal colic. ${ }^{368}$ This impact on health may not have always been immediate as recent skeletal analysis at the Wadi Faynan copper mines in Jordan have shown that only long term exposure created some of the more serious diseases. ${ }^{369}$ The prevalence of cremation burials at Alburnus Maior prevents a similar evaluation of remains. However,

${ }^{364}$ At Mons Claudianus in Egypt the quarry workers' rations where distributed in the valley where their wives made bread and other goods that were shipped to the quarry. It is possible women at Alburnus Maior worked both in sorting ores and domestic tasks. Hirt, Imperial Mines, 207.

${ }^{365}$ Healy, Mining and Metallurgy, 142. Grinding mills have been found a number of locals around Alburnus Maior. Davies, Roman Mines, 39.

${ }^{366}$ However, a hearth was found at Haba Sz. Simon near Alburnus Maior. Davies, Roman Mines, 199.

${ }^{367}$ This lead was not local and indicates extra effort was taken to supply the site with the needed ingredients for the process. The lead was similar to the rolls used in Spain and found in the debris of ancient work. Baron, "Lead isotope," 1094. Lead was often used in smelting where lead, salt, tin, barley bran and the gold ore were smelted together over low heat for five days. Recent experiments using this method recorded by Agatharcides, Strabo, and Diodorus Siculus have shown that salt was important and likely would be imported to the smelting site as well. Healy, Mining and Metallurgy, 151 and 154.

${ }^{368}$ The smelting of lead weakens bones and silver smelting causes anemia, muscular wasting and abdominal colic. J. Grattan et al., “'Death...more desirable than life'? The human skeletal record and toxicological implications of ancient copper mining and smelting in Wadi Faynan, southwestern Jordan," SAGE Publications 18 (2002): 304.

${ }^{369}$ As Grattan et al. point out in their study of the Wadi Faynan mines, only those who lived long enough in the location, such as conductores and engineers, would have adsorbed enough toxins to develop cancer. Copper mining is generally considered more toxic than gold mining which may suggest that the effects at Alburnus Maior would have been even slower. J. Grattan et al., "Analyses of Patterns of Copper and Lead Mineralization in Human Skeletons excavated from an Ancient Mining and Smelting Centre in the Jordanian Desert: A reconnaissance study,” Mineralogical Magazine 69 (5) (2005): 656. 
repeated references in the ancient world suggest the effects of smelting were well known. Pliny states that men working with metals covered their faces with animal skins or bladders to avoid inhaling toxic dust. ${ }^{370}$ Strabo describes efforts to build longer smokestacks on smelting ovens to get the "heavy and deadly" smoke high in the air, away from workers. ${ }^{371}$

The miners lived near the mines despite the known health risks and efforts were taken to improve conditions. At Alburnus Maior archaeologists note domestic structures were placed at a higher elevation to keep these spaces away from mining activities and the water used to process the gold. ${ }^{372}$ Nonetheless, dust likely covered domestic spaces and plants in gardens or grazed on by livestock that could absorb the toxins. ${ }^{373}$ At mines in Spain and Dalmatia, elaborate baths were built specifically for miners and, as was the case in Dalmatia, could surpass other provincial baths in their size and funding. ${ }^{374}$ The baths were leased to conductores and the access for miners was protected by law. ${ }^{375}$ There may have been a bath near Ampelum funded by the procurator $\mathrm{C}$. Aurelius Salvianus and the ordo Ampelensium. But at 35 kilometers ( 22 miles), the miners had

\footnotetext{
${ }^{370}$ Plin. NH 33.40 .

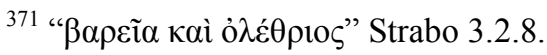

${ }^{372}$ Damian, Alburnus Maior I, 91 and 121.

${ }^{373}$ Besides water and surface contamination, the researchers also found evidence that these toxins were still present in goats grazing in the area of the abandoned mines. Grattan, "Mineralization in Human Skeletons," 656 and Grattan et al., "Wadi Faynan," 299.

${ }^{374}$ The baths at Domavia were built for the nearby silver mines and at over fifty rooms surpassed other baths in the province. It is likely that the initial baths were paid for by the imperial fiscus under the procuratores. Wilkes, Dalmatia, 378 and 381-382.

${ }^{375}$ Again the lex Metalli Vipascensis provides an example of the leasing terms and expectations of mining baths. ILS 6891.
} 
less than frequent access. ${ }^{376}$ Concerns about health were likely expressed through worship of Asclepius, the god of healing and medicine, at Alburnus Maior. ${ }^{377}$ While Apollo can be associated with gold, he was also a god of healing and appears four more times than Asclepius (6 to 2; see Appendix A).

This regional landscape was also scarred by the demands of the mining industry. For example, the amount of wood required for supports, sluicing structures, fire setting, and smelting was substantial. Strabo claims the logging near mines was so extensive that it created new farmland and the decrease of mining in Spain was partially blamed on a lack of available wood fuel after years of deforestation. ${ }^{378}$ The extensive mines at Dacia required major clearing of nearby timber which could create new hazards such as local flooding. $^{379}$

Perhaps it is not surprising that the god of forests, Silvanus, was popular at Alburnus Maior and is the second most attested deity (after I.O.M.) with eleven inscriptions (see Appendix A). An older Italic deity, he became popular in the Danube provinces among the rural and poorer populations. In Pannonia, Silvanus also became a protector of the household similar to the Roman Lares deities and this carried over to Roman Dacia where he was protector of both wild (Silvanus/Silvanus Silvester) and

\footnotetext{
${ }^{376}$ CIL III 1293. Noeske, "Goldbergwerke," 290. Since the site of Ampelum was destroyed, it is likely the presence of baths will remain uncertain.

${ }^{377}$ The use of the Greek Asclepius over the Latin Aesculapius may be from influence of the Greek culture in western Dalmatia as those erecting the monuments were likely from this region. Damian, Alburnus Maior I, 339-340.

${ }^{378}$ Strabo 14.6.5 and Craddock, Mining and Production, 194.

${ }^{379}$ Pre-industrial mining of copper required an estimated one million tress for one thousand tons of metal. Domergue, Les Mines Antiques, 45.
} 
domestic spaces (Silvanus Domesticus). ${ }^{380}$ At Alburnus Maior, Silvanus and Silvanus Silvester are the majority of the dedications at 8 and 3 respectively. Silvanus Domesticus only appears once and was worshiped more in the nearby towns. Silvanus Silvester is in the minority compared to his domesticated form at Ampelum (1 to 4) and Apulum (3 to 12). ${ }^{381}$ The needs of the industry and the rural environment were likely influencing his popularity and function at Alburnus Maior.

The demanding labor and unclean environment were further complicated by the hazards miners encountered underground. Standing water and flooded mines were a common problem noted at Alburnus Maior. On the wax tablet contract between the miner Memmius and the conductor Aurelius Adiutor, a flooded mine is provided as a specific example of a possible cause for work delays. ${ }^{382}$ Water wheels and Archimedean screws were used to bail out water at most mines. The Romans gained experience in expansive hydraulic mining as early as the first century BCE and incorporated large water wheels (with diameters of 4.3 meters/14 feet) to clear underground water up to 200 meters (656 feet) below the water table in Spain. ${ }^{383}$ Pliny the Elder writes that miners in Spain worked in shifts to make sure the water devices were constantly running. ${ }^{384}$ These same hydraulic devices were found in the Dacian mines, including five compartmented

\footnotetext{
${ }^{380}$ Silvanus literally means wooded or woodlands and specifically refers to wild or untamed forests.

${ }^{381}$ Damian, Alburnus Maior I, 343-344. Both Silvanus Silvester and Silvanus Domesticus are well attested in Dacia. Both forms appear at Alburnus Maior: Silvanus Silvester IDR III/3 405a and 406 and AE (1983) 823; Silvanus Domesticus IDR III/3 408. See also Appendix A.

382 "But if he is hindered by a stream/flood. /[Quod si] fluor inpedierit" CIL III p. 948 Tablet X.

${ }^{383}$ Domergue, Les Mines Antiques, 126 and Helmuth Schneider, "Technology," in The Cambridge economic history of the Greco-Roman World, eds. Walter Scheidel, Ian Morris and Richard P. Saller (Cambridge, UK: Cambridge University Press, 2007) 166 and Kehoe, "Production," 567.

${ }^{384}$ Shifts were determined by oil lamps. Plin. $N H$ 33.31.97.
} 
water wheels. ${ }^{385}$ In the Orlea massif at Alburnus Maior, water was drained from 75 meters (246 feet) underground with the aid of twenty-five water wheels installed in the second half of the second century CE. ${ }^{386}$ The Roman introduction of hydraulic technologies allowed the Dacian mines to be exploited deeper than before conquest. ${ }^{387}$ These wheels were operated by a miner or pair of miners treading the top rungs as they rotated, likely done in shifts as in Spain. ${ }^{388}$ This prevalence of water in underground mines likely impacted the health of miners. In Lucretius's first century BCE poem about the noxious airs in nature, he describes the evil fumes of the gold mines in Thrace that change the color of the men and made them weak. ${ }^{389}$ Modern scholars have suggested parasites in standing water, such as hookworm, were the real cause of this change in skin color and the weakness was the result of anemia. ${ }^{390}$ The miners were astutely aware of the problems caused by water in the mines and Neptune and other water deities were popular near Alburnus Maior.

More altars to Neptune were dedicated at Alburnus Maior than Ampelum and Apulum which suggests a connection to local conditions or preference (see Appendix

\footnotetext{
385 John Peter Oleson, Greek and Roman Mechanical Water-Lifting Devices: The History of a Technology (Toronto: University of Toronto Press, 1984) 331 and 195-196.

${ }^{386}$ Oleson, Water-Lifting Devices, 276-279.

${ }^{387}$ The deeper mines at Alburnus Maior utilized Roman technology. Baron, "Lead isotope," 1093.

${ }^{388}$ Oleson, Water-Lifting Devices, figure 31.

${ }^{389}$ Lucr. 6.769.

${ }^{390}$ Both gold and silver were mined and processed at Alburnus Maior. Damian, Alburnus Maior I, 485. Shephard, Rickard and others have also suggested these health side effects. Healy, Mining and Metallurgy, 137.
} 
A). ${ }^{391}$ Indeed, the dedications to water deities at Alburnus Maior outnumber those erected in the rest of Roman Dacia. ${ }^{392}$ In addition to Neptune, there were also dedications to the Nymphae and two possible Latinized Greek versions of Poseidon, Naoni (vaıv) and Maelantonius ( $\mu \varepsilon \lambda \alpha v \theta o \varsigma$ ?). ${ }^{393}$ In Dalmatia, the local water deity Bindus was combined with Neptune as Bindus-Neptunus by tribal leaders of the Iapodes who associated the god with mountainous springs instead of the sea. ${ }^{394}$ A similar association between Neptune and the mountains existed in Roman Dacia. But these water deities were more likely connected to the hazards presented by the substantial water encountered underground. Neptune's association with drowning may have been another reason for appeasing the deity.

In addition to flooding, the stability of the mine was another major concern. Pliny the Elder states that at the mines in Spain wooden pillars were used to stabilize the mines as cracks often appeared suddenly and crushed the laborers beneath. ${ }^{395}$ The lex Metalli Vipascensis from the second century CE specifically prescribed that wooden supports had to be utilized and maintained and any free man who undermined the structures would have his property seized and be banished from the mines. ${ }^{396}$ At Alburnus Maior, the niches for wooden supports are well attested and some wooden remains have been

\footnotetext{
${ }^{391}$ Neptune does not appear in the evidence from Ampelum and only once at Apulum - AE (1956) 204. Although still in the single digits, the five altars to Neptune/Poseidon at Alburnus Maior outnumber other communities of all Roman Dacia.

392 Wollmann, "Dacia Superior," 113.

${ }^{393}$ The altars to the Nymphs were raised next to others of Neptune on Hăbad Hill. Sorin Nemeti, "BindusNeptunus and Ianus Geminus at Alburnus Maior (Dacia)," Studia Historica. Historia Antigua 22 (2004): 95-96.

${ }^{394}$ Nemeti, "Bindus-Neptunus," 93.

395 "sidunt que rimae subito et opprimunt operatos" Plin. NH 33.21.

${ }^{396}$ ILS 6891.
} 
successfully carbon dated showing a range of use from the mid first century to the fourth century CE. ${ }^{397}$ Although similar laws to the lex Metalli Vipascensis have not been found, the increased longevity of a properly maintained gallery likely encouraged mining safety. ${ }^{398}$ In addition to wood supports, some pillars were carved from the stone to ensure stability in larger halls. This suggests that safety, or ensuring the stability of the mine, was more important than extracting every precious mineral available as these pillars still contain gold and silver ores. ${ }^{399}$

Other deities that could be associated with the unstable tunnels also appear at Alburnus Maior. Ianus, the two faced Roman god associated with gates and passageways, gained a unique popularity at the mines. He also represented transitions in time, used to commemorate beginnings, or spaces, such as between the tamed domestic space and the untamed wilderness. This god was popular in Noricum and western Dalmatia in areas adsorbed as client-kingdoms by Rome over a century earlier. ${ }^{400}$ To date, the only evidence of Ianus's cult in Roman Dacia is the four altars at Alburnus Maior where he is largely associated with the kastellum Ansis settled by miners from northwestern Dalmatia with both Illyrian and Celtic names. ${ }^{401}$ It is possible this god not

\footnotetext{
${ }^{397}$ Some earlier works also date to between the first centuries BCE and CE which again attest to the Dacian work in the mines before conquest. Damian, Alburnus Maior I, 475.

${ }^{398}$ Davies, Roman Mines, 200 and Damian, Alburnus Maior I, 485-496.

${ }^{399}$ Archaeologists considered the discovery of the mineral pillar in the Cârnic massif as doubly informative as the types of minerals being mined in the ancient world were also available from sampling the support. Damian, Alburnus Maior I, 484.

${ }^{400}$ Nemeti, "Bindus-Neptunus," 96. In fact, in regions like Dalmatia, Ianus Geminus also later had a political connotation as many dedications were raised by officials like the beneficiarii consulares. Wollmann, "Dacia Superior," 114.

${ }^{401}$ Nemeti, "Bindus-Neptunus," 97. Interestingly, unlike other Roman gods who had a Greek counterpart, Ianus was native to the Italian peninsula. Since Greek colonies were present in the western Balkans the longest, it could be argued some of the gods and their traits were influenced by the Hellenistic tradition as
} 
only protected mining passages and doorways but linked group identity for the colonists from Ansium as well. Dangers in the underground galleries might also be addressed to Terra Mater who appeared near entrances of the mines in other Danube provinces. One of her temples appears at the entrance to the mines at Rudnica in Moesia Superior (near m. Sočanica, Kosovo). ${ }^{402}$ Finally, Neptune was also known as a god of earthquakes and may have been worshiped to prevent underground disasters of both water and earth.

The mining communities at Alburnus Maior faced taxing labor and a contaminated environment. The presence of mining dangers, commotion, and industry waste had to impact their daily lives and, in the end, influenced religious ideas. Dedications to deities are often difficult to decipher when viewed alone. But the context of the mining experience provides some plausible connections between the deities and the miners who worshiped them. Religious spaces and these altars were directly connected to the mining settlements.

\section{Community Worship}

Religion is considered a highly conservative aspect of personal life that can be slow to change. Despite this longevity, the more personal aspects of faith are less apparent in historical study than the public expressions of religion. The mining settlements at Alburnus Maior had many public spaces set aside for group worship where Roman deities and Latin inscriptions are dominant. The evaluation of sacred space and religious membership shows that while Roman ideas were clearly influencing religious

well (again the Latinized names of Poseidon noted above). This was not the case with Ianus and his quick popularity in Dalmatia may again support the idea that this cult related closely to an indigenous deity. R. Joy Littlewood, "Janus," The Oxford Encyclopedia of Ancient Greece and Rome, Portland State University, accessed 28 February 2012.

${ }^{402}$ Damian, Alburnus Maior I, 296. 
identity, they were not adopted without changes and responded directly to local preference.

Sacred space was not limited to one locale: altars appear in community courtyards, cleared groves (luci), small shrines (sacraria), chapels (sacella), and other edifices that acted like temples. ${ }^{403}$ Each community at Alburnus Maior had its own cult and funerary spaces, which were often closely associated topographically. Archaeologists identify these sacred places using Roman terms. For example, the cult area at the Drumuş site near a natural spring is defined as a sacriarium or a sacred area reserved for a private edifice as defined by the second century jurist Ulpian. ${ }^{404}$ The altars and function of these areas seem to correlate to Roman use of religious spaces. But all sites do not offer a clear copy of Roman forms. The Drumuş second site illustrates this complexity as the inexact forms can be simultaneously defined as a temple (aedes/templum/delubrum), shrine (sacellum/sacrarium) or sacred grove (lucus). The altars were set on the eastern side of the temple which follows the Roman tradition mentioned by Vitruvius in the first century BCE. ${ }^{405}$ The courtyard and gallery were paved with stones mortared in yellow clay which is associated with Hellenistic sites. It is possible this influence came from previous experience with Greek construction in western Dalmatia or is a variation of a similar style already seen in the Norican-

\footnotetext{
${ }^{403}$ The archaeologists have recognized the likelihood of a sacred grove (lucus) or open aired temple and water source near the kastellum Ansium at the Hăbad site with twenty-six votive altars. Damian, Alburnus Maior I, 34, 127 and 257.

404 "[S]acrarium est locus in quo sacra reponuntur, quod etiam in aedificio private esse potest." Ulpian, Dig. I.8.9 quoted in Damian, Alburnus Maior I, 291-292.

${ }^{405}$ Vetruvius was a Roman architect who provided details of temple layout and expectations. Vitr. De arch. 4.5.1.
} 
Pannonian courtyards at the Tăul Ţapului and Hop-Botar domestic sites. ${ }^{406}$ These structures also changed over time. For example, at the Szekely edifice, where three possible sacella are identified, there is evidence that the structure was built as early as ca.107 CE. The initial exterior wall and central chapel used Roman design and measurement by pedes. Over time, the interior layout of the chapels shifted and became more like sacred spaces seen at Dalmatian and other Danube sites as they allowed space for more than one deity. Some archaeologists suggest that this was because "Roman plans were unskillfully used."407 But these spaces started with Roman dimensions and then changed which may suggest immigrant preference influenced structural changes that reflected community expectations for sacred space.

These religious sites provided space for community religious festivals and worship. Most of the material remains of offerings are gone; some ceramic evidence provides an indication of food preparation and storage possibly used in feasts. ${ }^{408}$ But even ceramic evidence does not retain well in the soil around Alburnus Maior and stone altars provide more evidence. $^{409}$ These altars show a variation in decoration and skill. At the Hăbad site several designs were erected concurrently, indicating that style was not always due to a change in fashion over time, but was a reflection of personal and group choice. Altars range from $40 \mathrm{~cm}$ to $80 \mathrm{~cm}$ in height and are made from local grit stone or

\footnotetext{
${ }^{406}$ Damian, Alburnus Maior I, 287 and 91.

407 Damian, Alburnus Maior I, 257-258.

${ }^{408}$ The Hăbad, Drumuş (T I) and Szekely religious sites provide evidence of ceramics such as jars and pots as well as plates, pitchers and cups. Ceramic lamps are also commonly found as well. Damian, Alburnus Maior I, 122-123, 287-288, and 259-263.

${ }^{409}$ Mihaela Simion, et al., Alburnus Maior II, Monumentul Funerar Circular $=$ The Circular Funeral Monument (Bucharest: DAIM, 2005) 141.
} 
sandstone. ${ }^{410}$ Although it is an imperfect estimate due to the inflation at the time, Diocletian's edict on prices in $301 \mathrm{CE}$ lists the service of stonemason at 50 denarii. $^{411}$ This cost was not out of range of miners earning salaries as seen in Memmius's contract. But the inconsistency of lettering and spelling may indicate that the dedicators were inscribing the monuments instead of professional stone masons. Some of the altars were "clumsily decorated" and inscribed with minor misspelled Latin such as Nimphis for Nymphis or a mixture of Greco-Roman letters as seen in the use of lambda $(\lambda)$ for ' $l .{ }^{, 412}$ Communities and their representatives varied in their finances and education but the funding of monuments was important even if they did not have all the tools or services available. The visual presence of the altar was more important than the inscription's accuracy and perhaps few would have noticed any mistakes.

These religious dedications and sacred areas were community focused and references to specific kastellum, several kastella, or collegia suggest most of the altars were financed by organized groups. Collegia in the Roman Empire functioned as professional organizations that provided commercial and social ties. Social aspects included a religious community that celebrated festivals together, dedicated altars, and ensured a funeral feast and burial for deceased members. At Alburnus Maior the development of large religious sites and the number of dedications in a rural area suggest the mining region had an "exceptional economic situation" that was likely due to a large

${ }^{410}$ Damian, Alburnus Maior I, 152-154.

${ }^{411}$ CIL III pp. 2208-2209.

${ }^{412}$ ILD 407. In a review of the twenty-seven inscriptions from the Hăbad site, one had grammar errors, four had letters in the wrong order, and thirteen had faulty letters. Damian, Alburnus Maior I, 128. Some seem to be a habit in the area. For example, at Drumus site the -ae is replaced by -e and this is seen on the wax tablets as well and seems typical in the Danube provinces. Damian, Alburnus Maior I, 295-296. 
contributing population rather than wealthy individuals or patrons. ${ }^{413}$ For example, the site at Drumus, associated with the natio Sardiatarum, was for a larger community as the Sardeates of western Dalmatia were likely too numerous to be in one collegia or kastellum. ${ }^{414}$ The expense of raising altars, let alone founding and maintaining sacred space, required group participation but the dedication was completed by an elected representative. ${ }^{415}$ Members of these organizations had some disposable income. If wages like those earned by Memmius were secured for many in the community, it is feasible that groups could raise the funds required for the development of religious space. ${ }^{416}$ This funding was necessary for the continuation of these groups. The legal dissolution of the Collegium of Jupiter Cerneni in 167 CE is detailed in one of the wax tablets found at Alburnus Maior. The members officially disbanded due to low enrollment numbers and the poor management of the commagister Julius, son of Julius, who no longer lived at Alburnus Maior. Without a strong membership, the collegium was no longer able to perform the duties expected, including facilitating meetings, festivals, funeral banquets, and last rites for their members. ${ }^{417}$

While collegia often united communities by profession in urban areas, this does not appear to be the case at Alburnus Maior as the associations were focused on

\footnotetext{
${ }^{413}$ Damian, Alburnus Maior I, 292.

${ }^{414}$ Damian, Alburnus Maior I, 290-292.

${ }^{415}$ For example, the altar erected to Terra Mater at the Drumus site (T II) by the sum [m?](e?) ele[(c)?]tis Damian, Alburnus Maior I, 296. This is seen again in the dedication by Celsenius Adiutor acting magister collegi. CIL III $7822=$ IDR III/3 385.

${ }^{416}$ Again Memmius contracted half a year (180 days) as a miner for 70 denarii. CIL III p.948 Tablet X.

${ }^{417}$ Of their fifty-four members, only seventeen remained. In part, Julius Juli was blamed because he did not remain at Alburnus Maior. This suggests some fluidity in where members of the collegia might live and work. CIL III p. 925 Tablet I.
} 
community and religion. ${ }^{418}$ Traditionally collegia around the Roman Empire focused on specific trades and kept membership restricted to professional association. ${ }^{419}$ These collegia protected business interests in addition to their social functions. There are no indicators of fabri (skilled carpenters, blacksmiths, etc.) like those at Apulum or, more aptly, leguli aurariarum (gatherers of gold) and collegium aurariarum (college of gold workers) found at Ampelum. ${ }^{420}$ There is one reference to a legulus (gatherer) in the early third century but, although M. Aurelius Maximus identifies his occupation, there is no clear indication that he dedicated the altar to I.O.M. for a professional association. ${ }^{421}$ Instead, most associations found at Alburnus Maior were focused on kastella or tribal groups such as the kastellum Ansi, collegii kastelli Baridustarum, or the collegii Sardiatarum. ${ }^{422}$ The preference for collegia with ethnic associations may have been in response to the diversity of relocated colonists. Indeed, dedications to the Genius of specific communities, such as the Baridustae and the Sardiatae from Dalmatia, further expressed the importance of settlement identity. ${ }^{423}$ Other collegia were focused on the

${ }^{418}$ Oltean, Dacia, 187.

${ }^{419}$ It was not unusual to see these collegia in smaller towns as groups as small as twelve are known. Usually collegia average 100 members and can be as large as 2000 in the larger cities like Rome. MacMillan, Social Relations, 73.

${ }^{420}$ CIL III $1307=$ IDR III/3 283 and CIL III $941=$ IDR III/3 235.

${ }^{421}$ CIL III $1260=$ IDR III/3 390.

${ }^{422}$ As will be discussed more below, these community identities appear on funeral monuments and in the wax tablet contracts as well as part of one's identity. On altars alone, we have the kastellum Ansi on five monuments (ILD 364, 368, 369, 376, 382, and 396), one reference to the Genio collegii kastelli

Baridustarum (IDR III/3 388), two for the Genius collegii Sardiatarum as well (ILD 401 and 396), and also a dedication to I.O.M by the collegii Sardiatae (ILD 398).

${ }^{423}$ To date, these include: Genio collegi(i) k(astelli) Baridust(arum) and Genio Sardiate(nsium), and [G]enio col(l)egi(i) Sar[di]atarum. IDR III/3 388, ILD 396 and 401. Interestingly, these inscriptions come from kastella with immigrants from western Dalmatia which was under Roman occupation the longest. This worship of the Genius of place may have been the result of incorporating Roman practice. As the kastella began to adjust with new immigrants it is likely membership that was focused with ethnicity or 
cult of a specific deity. Dedicators sometimes note their leadership such as the altar to Diana by Celsenius Adiutor, magister collegi, or their association seen on another to Silvanus by the son of Baotus and the collegium. ${ }^{424}$ Most of the dedications do not list the collegia (only 14 out of 81 ) and may be private dedications or altars placed in a religious space dedicated to the collegia where such a clarification was not needed (see Appendix A).

At Alburnus Maior the communities provided access to public worship and the means for expressing cult affiliation. Although membership is not usually automatic in collegia, they may have been more inclusive based on their popularity and connection with settlement over profession at Alburnus Maior. Perhaps accentuating the differences between communities had a greater appeal for creating clear and specific identities than one solely based on occupation where so many shared the same trade.

\section{Conclusions}

Local public identity at Alburnus Maior was largely influenced by the peculiarities of the mining district. Due to the massive colonization effort, many different groups were placed in the mining community where individual settlements offered a space for immigrants to organize by their origin affiliations. The names chosen did not follow a set pattern and suggest these communities chose names that further reflected a preference, such as urban or tribal identities, and spoke to their past experience under the empire.

origin from Dalmatia became gradually connected with the new communities and Genius of places in Dacia. Damian, Alburnus Maior I, 290.

${ }^{424}$ CIL III $7822=$ IDR III/3 385 and CIL III $7827=$ IDR III/3 402. 
Despite these local settlement identities, the inhabitants of the mining district shared the physical and environmental impact of the industry in their daily lives. These ubiquitous experiences encouraged the worship of common deities, with a few, such as Neptune and Ianus, gaining local or provincial significance beyond Roman expectations. The worship of these mining deities created additional group ties through membership in collegia and/or kastella and vici. As another aspect of local identity, these members prayed, feasted, and mourned together. Association with cult and settlement community became central to daily life and provided access to public expressions of group belief and identity at Alburnus Maior. How the individual, family, and clan fit into these state and local identities is the last aspect of identity that can be evaluated. 


\section{Chapter 5:"Private" Life at Alburnus Maior}

The evidence from Alburnus Maior points to an amalgamation of ideas used to communicate status, membership, and personal choice that move beyond the duality of Roman or non-Roman. Indeed, all of the inhabitants at the mines were aware of their membership in the empire, their local community, and clan and/or family. They made efforts to express all of these associations when available. Hybrids of various Danube, Roman, and Greek ideas are evident in the state and community aspects related above. At the personal or "private" level the interlacing becomes even more apparent. The evidence from funeral commemoration, naming conventions, and burial rites provide glimpses of an individual's identities. These identities communicated publically and privately several affiliations simultaneously through the hybridization of cultures.

\section{Commemoration and Naming Conventions}

Funerary monuments provide a static point for examining the identity of individuals, their families, and communities. How the dead were depicted and what was inscribed in their memory provides a glance at the dead and the living at that moment in time. Funerary monuments often varied from one community to the next and Dacia was no exception with artistic influences evident from the eastern, southern, and western neighboring provinces. ${ }^{425}$ Although the funerary feast and burial expenses were ensured by membership in a collegium, the funerary monuments celebrated the familial ties to the individual.

The miners at Alburnus Maior selected funerary monuments that were swayed by nearby urban styles but added their own local variation. During the second century CE,

\footnotetext{
${ }^{425}$ Marinescu, Funerary Monuments, 49.
} 
Italian, Pannonian, and Norican forms were reconfigured into a "baroque style" with deeply carved funerary figures found at Apulum. The portraits were often nondescript with the costume showing more variation than the faces. ${ }^{426}$ This style influenced monuments at Alburnus Maior as seen on the dedication for Aurelia Sambu in the early third century. She is depicted in non-Roman clothing and jewelry but her hairstyle followed the current Roman fashion. The preference to show dress and jewelry as markers of identity over individual portraits may suggest that group association was more important than personal physical characteristics. However, the "droopy ears" of the figures at Alburnus Maior contrast to the square jawed faces at Apulum and suggest that there were separate workshops that shared training but generated their own local differences. ${ }^{427}$ On many monuments, the deceased were depicted in a medallion which increasingly included the whole family over individuals. Parents and children were often squeezed into the same circle. On a stela from Alburnus Maior, a child's face was added awkwardly between the parents' portraits as the space below was already occupied by siblings. ${ }^{428}$ It was important to the family to include a portrait of each family member, regardless of space. Perhaps this highlighted the rare presence of full families in the district or the importance of lineage or both. Professions were rarely shown in the

\footnotetext{
${ }^{426}$ Marinescu, Funerary Monuments, 15, 28 and 70.

${ }^{427}$ Although archaeologists like Topál argue women showed the most resistance to change in burial customs, in the stelae artwork both men and women are depicted retaining non-Roman dress. However, the female hairstyles depicted popular fashions. For example, while the names on Sambu's monument provide a range of possibilities from the mid second century to the early third century, it is her hairstyle that has allowed her monument to be dated more closely. Marinescu, Funerary Monuments, 51-55, image S133. IDR III/3 416 with commentary by Russu, pp. 408-409.

${ }^{428}$ Marinescu, Funerary Monuments, 21 and 23, image S139. This focus on family over individual gained popularity in Dacia throughout the second to third centuries. Marinescu, Funerary Monuments, 47.
} 
artwork and even soldiers show a preference for civilian clothes than military dress. ${ }^{429}$ Unfortunately, at Alburnus Maior, the inscriptions add little to clarify the professions of those depicted and many monuments are incomplete.

The naming conventions and status of individuals is problematic due to the scarcity of evidence. In other Danube provinces the Roman tradition of raising a stone stela at burial was quickly adopted by families with Celtic and Illyrian names. ${ }^{430}$ Thus, the incorporation of inscriptions for both gods and epitaphs were not entirely new to the miners immigrating to Dacia. Nonetheless, there are few relatively complete funerary inscriptions from Alburnus Maior when compared to the number of religious monuments (17 to 82$).{ }^{431}$ The result is a rather narrow but still informative view of family and social status.

The names on the funerary monuments provide a glimpse at aspects of personal family life. Most of the names on the monuments, twenty-one out of thirty-five, were of peregrine status (see Appendix C). ${ }^{432}$ Of the eight men who had Roman citizenship, four of these were enfranchised after conquest. Marriage was not limited by citizenship status for these wealthier individuals. Women of peregrine status were married to enfranchised men while more peregrine men were wedded to women with Roman citizenship. One

\footnotetext{
${ }^{429}$ There is only one monument from Potaissa in Dacia Porolissensis with a man holding a hammer and pick. Marinescu, Funerary Monuments, 57, image S134 and 53-55.

${ }^{430}$ Noted in Pannonia as "superficial Romanization." J. Topál, "The connection between funerary rites and ethnic groups in the cemeteries of north-eastern Pannonia," in Burial, Society and Context in the Roman World, eds. John Pearce, Martin Millett, and Manuela Struck (Oxford: Oxbow Monograph, 2000) 197-198.

${ }^{431}$ Wilkes suggests that in Dalmatia funerary monuments were more likely made of wood as stone was difficult and expensive to acquire, this might be possible at Alburnus Maior as well where there is evidence of stone being carved by woodcarvers who perhaps were working in a new medium but not necessarily unfamiliar with engraving dedications. Wilkes, Dalmatia, 263.

${ }^{432} 63 \%$ were peregrine. For more details see Appendix C.
} 
peregrine woman, Andueia, daughter of Titus, was married to a Roman citizen, Valerius

Terentius, while three women with citizenship were married to peregrine men. ${ }^{433}$

Children are not absent from the burial record as a three year old girl and ten year old boy both had monuments raised by their grandfathers. ${ }^{434}$ The importance of family is evident in this small selection and all the dedicators list their familial relationship with the deceased. This practice is not unusual but in an area where community kastella and collegia associations were common, there might have been dedications between members who were not kinfolk. This is sometimes seen in rural communities with fewer families, such as military camps where one soldier raises the monument for the other. ${ }^{435}$ Although the current finds are not conclusive for the area, there may be some significance to the uniformity of commemoration focused on familial ties at Alburnus Maior.

In a region where men surely outnumbered women it is interesting to note that in the seventeen translatable funerary inscriptions from Alburnus Maior, eight were in memoriam for women and another two women appear as making the dedication (see Appendix C). This is the only clear evidence for women at Alburnus Maior other than the two slave transactions, one for a woman from Cyprus and the other for a six year old girl. ${ }^{436}$ As mentioned in Chapter 4, women were observed sorting ores at mining sites in other regions of the empire and this may have been one task performed by miners' wives

\footnotetext{
${ }^{433} \mathrm{CIL} 1272=$ IDR III/3 424, CIL III $1263=$ IDR III/3 413, CIL III $1262=$ IDR III/3 417, and CIL III 1266 $=$ IDR III/3 418. See Appendix C.

${ }^{434}$ CIL III $1269=$ IDR III/3 421 and CIL III $1264=$ IDR III/3 414.

${ }^{435}$ Obviously for military camps there was the legal prohibition to legal marriages. However, in a mining community where men undoubtedly outnumbered women, especially free women, and there were active collegia, it is interesting that not a single non-familial dedication has been found.

${ }^{436}$ CIL III pp. 937-939 Tablet VI from 139 CE and CIL III p. 959 Tablet XXV from 160 CE.
} 
and female slaves in the community. ${ }^{437}$ While monopolies over white bread, clothing items, and other goods may have changed some of the expected domestic duties of these women, it is likely they still engaged in domestic tasks such as spinning, weaving, cooking, and parenting. At Mons Claudianus in Egypt women prepared foodstuffs, such as bread, and other items before sending supplies to the extraction sites. ${ }^{438}$ It is possible some women and children lived at the heart of Alburnus Maior (unfortunately now gone) while their husbands lived at the mines. However, the cost of living space at extraction sites, such as the 300 denarii paid by Andueia, son of Bato, for half of a house may mean the whole family (if he had one) would stay at the mines where they could contribute both mining and domestic labor. ${ }^{439}$ Women of higher status, such as those married to a conductor, were more likely to live away from extraction sites either at Alburnus Maior or even as far as Ampelum. However, if they did live at Ampelum, their interment near the mines suggests their husbands had more responsibility or status among the mining community.

The importance of family ties is evident in the names given on inscriptions. The majority of the population at Alburnus Maior was of peregrine status until the edict of Caracalla which granted Roman citizenship to all free men in the empire in 212 CE. According to calculations by historian Rada Varga, about $75 \%$ of the names at Alburnus Maior were Illyrian which made up almost $2 / 3$ of the Illyrian peregrine names in the

\footnotetext{
${ }^{437}$ Diod. Sic. 3.13.1-2.

${ }^{438}$ Hirt, Imperial Mines, 207.

${ }^{439}$ CIL III pp. 945-947 Tablet VIII.
} 
province. $^{440}$ Illyrian languages are usually associated with the western Balkans, but onomastic studies often sweep wider to include the Danube provinces as Illyrian names appear in Noricum, Pannonia, Dalmatia, Moesia Superior, and Dacia. Therefore, although a name might be identified as Illyrian, it does not distinctly provide an origin without other evidence. This prevalence of Illyrian names does provide a clue at indigenous naming conventions. Illyrian inscriptions in the Danube provinces listed an individual's name with the father's name following in the genitive. ${ }^{441}$ Roman convention included filius/filia or $f$. with the father's name, a practice found only once on a monument for the deceased at Alburnus Maior. ${ }^{442}$ Without this identifier, the genitive following a nominative name implies the individual was a slave in other regions of the empire. $^{443}$ Instead, this combination is used to identify lineage at Alburnus Maior and is often the only identifier used for the deceased.

Beyond the inclusion of the father's name, few other forms of identification appear on the funerary monuments. For most, indigenous tribal names are rarely given with personal names suggesting that those who were using Latin did not find these ties relevant for commemoration. So far three references to the Sardeates and Delmatae have

\footnotetext{
${ }^{440}$ Interestingly, when compared to the whole province, Illyrian names make up almost $46 \%$ of the peregrine names present. This is only with the addition of Alburnus Maior (otherwise they are closer to $20 \%$ ) which suggests either our evidence from the mines is better or more Illyrians traveled to the gold mines for opportunity rather than the large urban centers. Varga, "Peregrine Names," 239 and 242.

${ }^{441}$ Unlike Roman convention, fathers of peregrine status did not pass their same name to their sons. Instead, this inclusion of 'son of' clarified the relation than naming Giaus's son Giaus. Varga, "Peregrine Names," 239.

${ }^{442}$ A peregrine, Panes, son of Biso, (Panenti Bizonis $f(i l i o)$ ) is identified by his uncle who dedicated the monument. AE (2008) 1167. It remained important for the living to describe their familial relationship to the deceased but was not part of the naming convention.

${ }^{443}$ Varga, "Peregrine Names," 235 and 238.
} 
been found, both tribes originally from Dalmatia. ${ }^{444}$ The inclusion of a residence or domus is also rare on the funeral monuments at Alburnus Maior. This inclusion of a domus was less common in Dacia as a whole. At Apulum alone, in over seven hundred inscriptions only twenty-seven specify domus or ethnicity directly. ${ }^{445}$ In most provinces this number is much higher as colonists tended to promote their different origin from the local population. ${ }^{446}$ The high number of immigrants created a unique province where those presenting the most difference were other colonists rather than the indigenous population. Local community became more important and three inscriptions identify the local kastellum of the deceased. ${ }^{447}$ Only one identifies a municipality, Aequum, Dalmatia (m. Čitluk, Croatia). Since Aequum was a colony since $42 \mathrm{CE}$, its inclusion may have purposefully accentuated the fact that the deceased was a Roman citizen. ${ }^{448}$ In part, tribal or resident affiliation was likely unnecessary in cemeteries divided by community. But recent evidence shows these necropolises were not as homogeneous as once thought. And small familial or clan plots may suggest burial location was chosen by family after the funerary feast was performed by the collegium. Instead of group or origin identity, it

\footnotetext{
${ }^{444}$ CIL III $1266=$ IDR III/3 418 and AE (2008) 1166 and 1167. Damian, Alburnus Maior I, 151. Interestingly, the monument for Cassia Peregrina, a Roman citizen was dedicated by her husband Bisius, son of Scenobarbus, of the Sardeates which again illustrates the partnerships between those with different citizenship status. Noeske, "Goldbergwerke," 377.

${ }^{445}$ Oltean, "Dacian Ethnic Identity," 94.

${ }^{446}$ D. Noy, "Epigraphic evidence for Immigrants at Rome and in Roman Britain," in Roman Diasporas: Archaeological Approaches to Mobility and Diversity in the Roman Empire, ed. Hella Eckardt (Portsmouth: Journal of Roman Archaeology, 2010) 25.

${ }^{447}$ Kastellum Starvae AE (2008) 1166 and 1167 and kastellum Anso/is CIL III $1271=$ IDR III/3 422.

${ }^{448}$ Avillia Pietas was a Roman citizen but her husband who dedicated the monument, Dasa, son of Suttis, was not. CIL III $1262=$ IDR III/3 417.
} 
appears that expressing family ties was the most important to commemorate in inscription for those who erected these funerary monuments at Alburnus Maior.

Nonetheless, the choice in names still conveyed ideas of status and even membership in the Roman Empire. The negotiation of Latin and indigenous naming conventions are evident on the funerary monuments and other written sources, such as religious altars and the wax tablet contracts. There is evidence that some Roman names were adopted before miners became citizens. These names were sometimes misspelled (Maxsimi) but appear frequently; Maximus appears seven times in the peregrine names evident in the contracts and epigraphic record. ${ }^{449}$ When they received citizenship, not all miners adopted a Roman tria nomina but instead added a third name that might be Roman or Illyrian. In this form, the first two names adhered to peregrine convention in the area and listed the individual's name followed by the father's name in the genitive. For the new citizens, this name was then connected with a qui et (who is also) followed by an agnomen or nickname. For example, Verso, son of Dasius, who is also Veidavius (Verso Dasantis qui (et) Valdavius) kept Illyrian names for all three while Planius, son of Baezus, used the Roman title Magister as his agnomen (Planio Baezi qui et Magistro). ${ }^{450}$ Those who did adopt the tria nomina often retained ties to non-Roman names. For example, Aellius Quintus Dius had adapted and maintained the Greek name Dion $(\Delta \mathrm{tov})$

\footnotetext{
${ }^{449}$ The misspelling Batonis Maxsimi or Baton, son of Maxsimus(?) appears in the wax contract from 159 CE. CIL III p. 929 Tablet II. Possibly this name became popular as a name of rank as Maximus Veneti, a peregrine princeps stood as a witness in for a slave purchase. The purchaser of the slave girl, Maximus Batonis is also of peregrine status. CIL III pp. 937-939 Tablet VI. Other appearances are found in CIL III 1261, IDR III/3 420, 421 and 423.

${ }^{450}$ ILD $405=$ AE (2003) 1495 and CIL III $1270=$ IDR III/3 423. See also the discussion in Damian, Alburnus Maior I, 342-342 and Noeske, "Goldbergwerke," 385.
} 
in Latin form and Marcus Aurelius Scenobarbus retained the Illyrian Scenobarbus. ${ }^{451}$ Other miners who likely attained citizenship after their move to Alburnus Maior changed to completely Latin forms, such as Marcus Aurelius Maximus and Marcus Aurelius Superianus. ${ }^{452}$ Therefore, while peregrine naming conventions stayed relatively consistent, the incorporation of Latin names and change in citizenship status was expressed in several different ways. For the majority at Alburnus Maior, it appears that some retention of indigenous names was preferred over purely Roman tria nomina.

From the type of art to the use of Latin names, the inhabitants of Alburnus Maior were selective in how they represented the individual to convey several different meanings. Indigenous dress might indicate community affiliation while a hairstyle incorporated Roman fashion. Likewise a Roman tria nomina could include an Illyrian name. In both of these instances the individual communicates a dual membership in local community and the empire. The number of ways these ties were expressed suggests a choice by the individual and family or clan. This mixture of ideas and personal choice appears again in individual burial.

\section{Burial Rites}

In addition to the funerary monuments, the burials themselves illustrate a mixture of several cultures. Five cremation necropolises combined with two funerary areas have provided a large sample of data from Alburnus Maior. ${ }^{453}$ These sites show there was

\footnotetext{
${ }^{451}$ ILD 401 = AE (2003) 1491 and CIL III 1265 = IDR III/3 415. See also Damian, Alburnus Maior I, 304305.

${ }^{452}$ CIL III $1260=$ IDR III/3 390 and IDR III/3 391. See also Noeske, “Goldbergwerke,” 378.

${ }^{453}$ The five cremation areas are at Hop-Găuri, Pârâul Porcului/Tăul Secuilor, Tăul Cornii, Ţarina, and JigPiciorag with two funerary spaces at Carpeni and Szekely. Paul Damian and Mihaela Simion, "Funerary Practices in the Necropolises belonging to the ancient communities at Alburnus Maior," in Funerary
} 
some "parceling" of areas to families or clans, which was common in other Danube provinces. The macro view of the necropolises indicates the presence of multiple groups with varying ways of interring the dead that date to the same time and therefore do not represent a change in tradition or fashion. ${ }^{454}$ Among the 169 incineration graves at the Hop-Găuri site, seventy-eight were bustum cremation and the other ninety-one were ustrinum cremation. Bustum graves involved cremating the dead at the site of burial over a square pit or the more common step-pit grave which included two depth levels with the upper portion making a step around the edge. Ustrinum graves were filled with the remains of those cremated elsewhere, usually a public funerary space used by multiple families, likely maintained by a collegium. ${ }^{455}$ Both types of graves were sometimes accompanied by a ring structure encircling the grave. This was more common for indigenous groups in the Danube provinces and is not recognized by archaeologists as a Roman practice. ${ }^{456}$ One cremation style was usually favored in different regions but Alburnus Maior shows an equal mixture. Additionally, while bustum step-pit graves were popular around Alburnus Maior, they were not common in the rest of Roman Dacia. Instead, this grave style was common for indigenous burials in other Danube provinces

Practices in Europe, before and after the Roman Conquest $\left(3^{\text {rd }}\right.$ century $B C-3^{\text {rd }}$ century AD), ed. Valerius Sîrbu and Sabin Adrian Luca (Alba Iulia: Ed. Altip, 2007) 141.

${ }^{454}$ Damian, Alburnus Maior I, 209 and Parceling is well attesting in Pannonia. Topál, "Pannonia," 537.

${ }^{455}$ Damian, Alburnus Maior I, 208 and Damian and Simion, "Funerary Practices,"142-144.

${ }^{456}$ Damian and Simion, "Funerary Practices," 144 and Damian, Alburnus Maior I, 210. These rings are usually circular which is different than the Dacian pre-conquest cremation which was enclosed by a rectangular ring. Simion, Alburnus Maior II, 170. Both circular and rectangular rings were noted in the cemeteries around Ampelum. Rectangular rings are further attested north at the necropolis of Porolissensis for ustrinum graves. A. Alföldy-Găzdac et al., "Project 'Necropolis Porolissensis' Methods and Perspectives," Acta Terrae Septemcastrensis 6 no. 1 (2007): 10-11 and 12. 
including Pannonia, Moesia Superior and Inferior, Thracia, Dalmatia, and Macedonia. ${ }^{457}$ Attesting to its popularity, the bustum step-pit graves make up $60-90 \%$ of the graves in rural regions of Pannonia and Moesia Superior beginning in the first century CE. This cremation preference was maintained in some Danube regions by indigenous populations near growing Roman urban centers until the third century CE. However, these graves are generally associated with mines and the "translocation of miners" throughout the provinces. $^{458}$

The burial inventory around Alburnus Maior reflects that grave goods were influenced by wealth, status, and access to items. While some cemeteries had more stelae than others, the necropolises were often mixed and had nondescript and monumental graves near one another. ${ }^{459}$ In archaeologist Claude Domergue's recent survey of mining graves around the empire, inventory was generally poor and the majority, $60 \%$, had no grave goods. Those with more than one item made up less than a quarter. ${ }^{460}$ Most graves at Alburnus Maior do not have rich inventory, but items such as lamps, ceramics, and iron objects are common. ${ }^{461}$ Ceramics are generally of Roman manufacture but local pieces are found as well. At the necropolis at Tăul Secuilor, 321 graves yielded 308 lamps, eighty three bronze coins, one silver denarius, fifty eight glass

${ }^{457}$ Simion, Alburnus Maior II, 158.

${ }^{458}$ A. Jovanović, "Romanization and ethnic elements in burial practice in southern part of Pannonia Inferior and Moesia Superior," in Burial, Society and Context in the Roman World, eds. John Pearce, Martin Millett, and Manuela Struck (Oxford: Oxbow Monograph, 2000) 205-206 and 209.

${ }^{459}$ For example the Hop-Gauri site had similar cremation variation as those at Ruda-Brad but more epigraphic texts were at the latter site. Damian, Alburnus Maior I, 210.

${ }^{460}$ Only 23\% had more than one item. Archaeologist Claude Domergue who specializes in the Spanish mines provided the estimates (Les mines de la Peninsule Iberique dans l'antiquite romaine, 1990). Damian, Alburnus Maior I, 210.

${ }^{461}$ Iron nails and spikes are the most common with iron knives and plates also appearing at times. For examples, see the inventory from the Hop burial site. Damian, Alburnus Maior I, Chapter 2.5. 
unguentaria, and two bronze mirrors. Only one gold item was found at Tăul Secuilor while more gold ornaments were found in the 495 graves at Ţarina. ${ }^{462}$ Thus, while those with wealth and of higher status were not absent from these cemeteries, they were in the minority. There does not appear to be a discernible difference between the type of cremation and the grave goods used. Lamps, various ceramics, and iron items are common in both. More difference is seen in how the items are deposited. For example, in the ustrinum graves an extra ceramic urn or stone cista might be used to hold the ashes and special items such as coins or an unguentarium. ${ }^{463}$ Finally, while grave goods vary, there are few unique items not found elsewhere in Roman Dacia. The one exception are the graves containing quartz which is associated with mining cemeteries as this mineral was found in other mining necropolises in the Danube provinces. ${ }^{464}$ The miners were utilizing their access to common provincial goods while adding items that linked them directly within the mining profession and community.

A few burial monuments visually dominated the landscape and used a mixture of mediums that clearly incorporated several ideas for communicating prestige and identity. In addition to the stone rings around cremation plots mentioned above, mounds were also raised that defined the graves from others in the necropolis with earth and stone. ${ }^{465}$

Tumulus tombs are more elaborate mounds of earth that may include a larger central

\footnotetext{
462 cIMEC Archaeological Reports 6770.04 and 6770.06, http:// ran.cimec.ro/.

${ }^{463}$ Lamps and iron nails or tacks are still placed in the larger pit. Damian provides a good comparison of bustum and ustrinum graves with case studies from the Pârâul Porcului/Tăul Secuilor site. Damian and Simion, "Funerary Practices," 142-144.

${ }^{464}$ Although found in other areas around Alburnus Maior, it is interesting that many were found in poorer graves like those at the Hop-Găuri site. Damian, Alburnus Maior I, 209.

${ }^{465}$ Simion, Alburnus Maior II, 133.
} 
chamber and have been found in four necropolises at Alburnus Maior. They are intermingled with the simpler ustrinum and bustum cremation graves. ${ }^{466}$ These tombs were not unknown in the Roman Empire and during the reign of Hadrian the style regained popularity in the Danube provinces. ${ }^{467}$ The tumulus tombs at Alburnus Maior appear in the second century and contain bustum step-pit graves. This combination of monument and cremation style is often associated with Moesia Inferior and Thracia where the form became popular again towards the end of the first century. ${ }^{468}$ But this form of burial was also used in Dalmatia and Pannonia. ${ }^{469}$ At Alburnus Maior these graves are situated among several groups including the Dardanians from Moesia Superior and the Pirustae from Dalmatia. ${ }^{470}$ In these other provinces the revival of the form is generally interpreted as a response by the indigenous elite reasserting their position in society after conquest. The use of these monuments near Roman urban centers did set these graves apart in the necropolis. ${ }^{471}$ But at Alburnus Maior these tombs contain both Roman and indigenous elements which suggest the monuments were not necessarily subversive or anti-Roman and are better examined as a new form.

\footnotetext{
${ }^{466}$ Tumulus tombs are at Pârâul Porcului/Tăul Secuilor, Tăul Cornii, Hop Găuri and Jig-Piciorag. Damian and Simion, "Funerary Practices," 144.

${ }^{467}$ Circular funeral monuments were used in the Roman Empire since Augustus. Simion, Alburnus Maior II, 171 and 134.

${ }^{468}$ Jovanović, "Pannonia Inferior and Moesia Superior," 207-208, Damian and Simion, "Funerary Practices," 145 and Simion, Alburnus Maior II, 164. This combo of tumulus and bustum grave was also popular in the first century BCE and was evident in areas of Dacia before conquest. Oltean, Dacia, 108109.

${ }^{469}$ Simion, Alburnus Maior II, 159 and Mócsy, Pannonia and Upper Moesia, 152.

${ }^{470}$ Alföldy-Găzdac, “'Necropolis Porolissensis,” 12.

${ }^{471}$ Simion, Alburnus Maior II, 161.
} 
The elaborate circular funeral monument at the Basil Cozma site offers a clear case study where indigenous customs incorporated Roman technology to communicate economic and social status. The monument sits at the bottom of a slope, similar to an amphitheater in shape, 250 meters southwest of the Hop-Găuri necropolis at Alburnus Maior. The tomb was visible from the road leading up the plateau and possibly marks the boundary of the cemetery. ${ }^{472}$ Between this main necropolis and the monument are additional enclosures and funerary clusters along the southern slope. ${ }^{473}$ A few nearby graves outside the monument were cremated at ustrinum and may belong to a different family or tribe. ${ }^{474}$ The tomb is eight meters in diameter and contains two graves cremated in bustum step-pit graves. This circular monument was erected over an earlier form of tumulus tomb and the deceased were interred at different times. The items found in the monument are similar to the grave goods deposited elsewhere around Alburnus Maior and include lamps, local ceramics, iron nails and tacks, and coins which date the monument between Hadrian and Antoninus Pius (ca. 117-161). ${ }^{475}$ Bronze belt plates may indicate the deceased was a soldier, but the lack of other related military goods suggests it could be a member of the civilian elite, such as princeps or wealthy conductor, as well. ${ }^{476}$

The change in construction and ornamentation between the first and the second tumulus tomb on this site shows the gradual introduction of urban ideas. The first form

\footnotetext{
${ }^{472}$ Simion, Alburnus Maior II, 112 and 127 and Virgil Apostol, "Funerary Architecture in Alburnus Maior (Roşia Montană): The Circular Monument," Dacia N.S. 48-49 (2004-2005): 251 and 270.

473 Apostol, "The Circular Monument," 249.

${ }^{474}$ Simion, Alburnus Maior II, 114-115 and 157.

${ }^{475}$ Simion, Alburnus Maior II, 141-143 and Apostol, "The Circular Monument," 273.

476 There are other military graves at Alburnus Maior with more bronze and iron items including weapons or armor which suggest this grave is not one when compared. Soldiers have been found at Carpeni Hill and Taul Cornei. Simion, Alburnus Maior II, 146-147.
} 
of the monument was a large tumulus tomb with a wall of irregular stone bound in yellow clay. This construction is similar to other buildings found around Alburnus Maior built by the miners which suggests this earlier tomb was not for a soldier or state official but an important member of the mining community. The second monument was not mortared but constructed with stone locked into place with internal wooden grooves which was likely done by a professional mason. ${ }^{477}$ The exterior wall was finished smooth but lacked any base embellishment common in Roman mausoleums. In Ulpia Traiana Sarmizegetusa the Mausoleum of the Aurelii also lacks any embellishment at the foot of the monument which suggests this was a provincial preference or style. ${ }^{478}$ The only surviving adornments are the much faded lions that would have crowned the east façade and likely held a medallion depicting the deceased. ${ }^{479}$ The lions were a popular motif in Roman Dacia. Their origin is uncertain as it appears in Moesia Inferior, Dalmatia, Noricum, and Pannonia as early as the first century CE. ${ }^{480}$ The lions became popular in Dacia during the third century. ${ }^{481}$ Despite the Roman façade, the interior cremation rites of the second grave show a continuation of Illyrian or Thracian personal religious beliefs.

\footnotetext{
477 Apostol, "The Circular Monument," 251 and 258.

${ }^{478}$ Simion, Alburnus Maior II, 134 and 187. However, the execution is not the same and the circular funeral monument is more reflexive of the building techniques near Alburnus Maior and Ampelum. Simion, Alburnus Maior II, 170-171.

${ }^{479}$ Simion, Alburnus Maior II, 138. The grooves indicate the lions held some plaque ore medallion. Since medallions were popular in the area this seems likely. Apostol, "The Circular Monument," 251.

${ }^{480}$ Marinescu, Funerary Monuments, 12-14 and 43.

${ }^{481}$ Although lions are sometimes associated with members of the Mithras Cult, the popularity in Dacia suggests the motif lost this meaning. Marinescu, Funerary Monuments, 23 and 43.
} 
The continued evolution of the tomb near the road emphasizes the importance of the visibility of the monument. Unfortunately there is no direct marker that describes how these elite were associated with the mines. But the visibility of the monument strongly suggests this family or clan was connected and their status within this community mattered. Externally the tomb was gradually reconstructed with Roman technology that included adjustments that followed local provincial style. At the same time, the interior interment of the dead followed indigenous tradition in both the construction of the step-pit grave and the cremation of the remains. Instead of illustrating an incomplete understanding of Roman monumental practice or a private resistance to Roman norms, the circular funeral monument provides an example of how identity fluctuated and incorporated new ideas. At Alburnus Maior, the deceased could maintain family traditions and belief while communicating their local influence and power using Roman technology and forms that acted as a visual lingua franca to the larger mining and provincial community.

The inscriptions commemorating individuals at Alburnus Maior were directed by the family rather than the mining community or collegia. Local cultural influences were apparent in the inclusion of common goods like lamps and professional markers like quartz. The availability of cheap Roman goods and specialty items like glass unguentaria also created some commonalities between grave types. The different burials interred within close proximity to one another suggests burial rites reflected personal preference that likely said more about family or clan identity than community expectations. Conversely, the outer markings of stone rings, funerary stelae, and tumular 
monuments likely showcased the family's ability to inter their dead at a greater expense and conveyed their status in the community.

\section{Conclusions}

The evidence from naming conventions to grave goods shows that few influences were accepted without some adjustment and variation. Even the most expensive monumental representations of identity included aspects that cannot be pinpointed to one particular region of the empire but instead illustrate the melding of several traditions. With an eye to empire wide conventions of tria nomina, the immigrants purposefully chose how they shifted their names to reflect Roman citizenship. While some adopted Roman conventions directly, others retained names that expressed their status in the empire but continued to communicate their affiliation and identity in their local community. The naming conventions on funerary monuments further highlight this tendency. Family ties, perhaps rare in a male dominated industry, are highlighted in funerary commemoration. The individual portraitures focused on indigenous dress and jewelry rather than faces which suggests group association was more important.

The only private aspect of identity may be the interment of the dead, but this too was influenced by family or clan expectations and the availability of grave goods. Unfortunately, there is no definitive explanation for the preference of one type of cremation over the other or the reason behind the inclusion of items like quartz. While the ustrinum or dedicated burning area is often associated with wealthier individuals or collegia in the western empire, the prevalence of bustum graves in the Danubian provinces may speak equally to a regional preference than a delineation by economic status. The continuation of several types of burial interred at the same time suggest that 
these last rites remained specific to an individual's identity and, like naming conventions, was selectively changed. 


\section{Chapter 6: Conclusion}

The Second Dacian War did not annihilate the Dacian population but major Late Iron Age urban centers were destroyed and the local elite were eliminated from central leadership. New urban colonies and settlements became the focus of civic life under one of the largest colonization efforts of the Roman Empire. As noted in Eutropius's account, Trajan transplanted many people (copias hominum transtulerat) to promote urbanization and agriculture in the new province. Epigraphic evidence substantiates that colonists in Dacia came from all over the Roman Empire (ex toto orbe Romano). ${ }^{482}$ The marginalization of the indigenous population refocused the negotiation of cultural and societal norms among these immigrants. Not all of these colonists were Roman citizens and each brought their own past experiences and expectations that influenced their provincial, community, and personal identities.

The mining community at Alburnus Maior provides a focused case study of identities in this heavily colonized province. The proactive efforts to supply the miners with goods by the procurator aurariarum and his staff suggest the experience and reaction of this community may not easily translate to other rural areas. This case study could provide an example for comparison with other imperial mines during the second and third centuries. However, the substantial efforts to colonize Dacia with sizeable groups of miners from several regions and provinces may make this immigrant community more diverse than other large mining operations like those in Dardania, Moesia Superior or near Domavia, Dalmatia. Instead, this case study substantiates how

\footnotetext{
482 "Trajan, having conquered Dacia, had transported an infinite number of men there from the whole Roman world to tend the fields and cities. / Traianus victa Dacia ex toto orbe Romano infinitas eo copias hominum transtulerat ad agros et urbes colendas." Eutr. 8.6.2.
} 
diverse evidence can distinguish levels of identity within a community and highlights trends that may prove prevalent in the immigrant experience.

\section{$\underline{\text { Identities at Alburnus Maior }}$}

The combination of epigraphic, written, and archaeological evidence supplies the opportunity to examine how several cultural expectations were adapted to everyday life. The many expressions of identity - government association, origin, status, wealth, employment, law, language, literacy, location, and religion - offer a means for evaluating cultural interaction and social expectations. Although this approach could not feasibly represent every individual at Alburnus Maior, the case study still offers insights into the identity of some miners, conductores, and specialists living near the mines. Three levels of identity (state, community, and individual) coexisted and likely fluctuated in importance depending on circumstance.

Those living and working at Alburnus Maior wanted to express their affiliation with the Roman Empire regardless of their legal status. They were familiar with ways of enunciating their state identity through the continued presence of the procurator aurariarum and his staff, military personnel (especially the beneficiarii consularis), and their native representatives, or principes. Just as important, they were able to express these ideas with the consistent availability of items brought into the rural district and the money to purchase these items through salaries and collective funds. The mining community raised monuments to the imperial cult, I.O.M., and possibly continued the imperial mining pantheon that focused on Terra Mater. They inscribed these monuments in Latin, which served as a universal language in the district. Native languages were likely used in domestic areas, but the use of Latin inscriptions within and near these 
settlements suggest that the language prevalent in the functioning of the mines also influenced everyday communication. Additionally, miners were proactive in utilizing Roman contracts to protect their rights within Roman legal standards. Here again, members of the local hierarchy acted as witnesses which may suggest they encouraged and introduced the use of Roman law. The use of Latin and contracts was used by those who considered themselves participants in the empire despite the limitations in their knowledge and access. Conversely the celebration of state cults, such as I.O.M., were not limited by their status but instead relied on their association with groups within the mining community.

Group religious identity focused around settlement and collegia membership. Settlements were initially named after a shared group origin, either urban or tribal, and although these group identities became more associated with local (rather than transprovincial) identity over time, they remained central to the miners' daily life. Contrary to Roman expectations of collegia, these fraternities at Alburnus Maior were not focused on occupation. Instead they were created for a particular deity or forged from the settlements themselves. These collegia pooled group funds to provide religious feasts, funeral banquets, and last rites in addition to raising altars. All of these acts continued to strengthen group affiliation. Roman collegia in urban centers also provided a venue for trade groups to protect their interests and profession. Perhaps the miners saw little reason to specialize membership by pickers, smelters, or washers if these jobs were under different conductores and/or mixed with laborers from other settlements. Additionally, the interests of the individual settlement communities likely superseded any professional connections. Indeed, it is plausible that the strong focus on community forged fraternities 
that included conductores, specialists, and miners who would be separated under usual Roman custom.

Membership in settlements and collegia offered a means to participate in public worship which was clearly associated with the mining industry. Religion at Alburnus Maior responded to the immediacy of mining in everyday life. Deities addressed concerns from the dangers of underground floods and cave-ins to the maintenance of abundant resources. Although a few Latinized gods from other cultures appear in the inscriptions, such as the Celtic Aerecurae, most names are Roman. The popularity of gods like Liber and Libera, Ianus, Silvanus, and Neptune in other Danube provinces shows that these deities gained additional or modified meaning. Other gods may have also taken on new local traits now lost. These dedications to deities like Neptune in new surroundings with adjusted meaning suggest that these gods were no longer native or Roman but a new hybridization. These new deities were important to religious identity as attested in the eighty-two dedications found to date.

Finally, individuals balanced Roman and community identities with the expectations of family and personal preference. Peregrine naming conventions expressed lineage and the retention of peregrine names in the tria nomina by citizens communicated their continued group affiliations within their new Roman legal identities. Legal status did not limit personal life as marriages between peregrinae and citizens are well attested. Such alliances are not unknown in the Roman Empire and these were likely similar in that the daughters of citizens may have married peregrine settlers of higher status, perhaps conductores at the mines, who were wealthy enough to erect the monuments in their memory. Families were certainly outnumbered in a profession dominated by men 
and perhaps this encouraged the dedications of monuments that make every effort to commemorate family ties.

The final burial act was likely chosen by the family or individual and retained personal preference. The presence of bustum and ustrinum cremations interred at the same time illustrate that burial traditions were not easily changed. Even in communities like kastellum Ansis, where group religious dedications are well attested, these group ties were not expressed in a universal burial custom. Again, at the Hop-Găuri burial site associated with this kastellum, the types of cremation graves are split almost evenly. Nonetheless, while the interior burial rites remained a personal choice, the exterior often communicated group identity. The hybridization of Balkan and Danubian tumulus tombs with Roman memorials found in the circular funeral monument at the Basil Cozma site illustrates how several ideas were melded to express an individual's identity. The interior internment expressed personal choice while the outside expressed status and membership in the local mining community. The selective adoption of Roman building techniques and ornament identified the individual further as a member of the empire. Although the exact message of many burial customs and symbols cannot be satisfactorily deciphered, the materials available show that individuals retained their multifaceted identities in death.

The Immigrant Experience

The case study of Alburnus Maior highlights several trends in the immigrant experience in the Roman Empire. The creation of defined communities in a new territory was central to daily life and facilitated the participation in local cult. Placed near exploitation sites, new settlements were not only the focus of daily labor but created 
domestic space and community. These immigrant settlements used their origin to delineate group identity and formed collegia to maintain collective benefits. Group membership provided the opportunity for immigrants to pool funds for local and state cults while individuals were also assured funerary observations and burial. These combined benefits made communities invaluable for immigrants.

An empire-wide conscious state identity was facilitated among immigrants in a district where the imperial and military administrators kept a continued presence. It is likely immigrants found it important to express their affiliation with the empire in a foreign territory and new community where their livelihood depended on the continued success of the state. Most miners were not legally citizens and four generations would pass after the initial immigration before the Edict of Caracalla granted all free males citizenship in 212 CE. Nonetheless, the participation of civitates peregrinae and their collegia in state cults with Roman style monuments inscribed in Latin suggests that some did perceive this affiliation as part of their identity. But the varied incorporation of the Roman tria nomina and the local adaptation of Roman deities illustrate that miners still incorporated their Roman membership selectively. These inconsistencies reflect a continued flexibility in the interpretation of how one expressed Roman identity in immigrant communities.

Finally, the material culture that survives illustrates the clear influence of Roman culture on immigrants with access to examples and goods. From Latin inscriptions and contracts to the use of Roman deity names, it is clear that Roman forms became the dominant mode of expression in mediums that have survived. But the examination of the individual graves shows that identity was more fractured and the hybridization of several 
cultural ideas is evident. This suggests that immigrants balanced several identities and several meanings were likely melded into Roman forms that are not immediately apparent.

The rural community of Alburnus Maior provides a unique case study of identity in the Roman Empire. The draw of the gold mines and the mobility of groups and individuals from several provinces created a large immigrant community. These miners coped with this diversity by creating separate settlements that forged new local group identities. These groups supported immigrants as they worked with the imperial fiscus and other mining settlements to contend with the harsh realities of the mining industry. Settlements were not only residential but central to daily labor, community worship, and individual commemoration and burial. The miners responded to the experiences at Alburnus Maior utilizing Roman forms while they continued to incorporate indigenous group and individual expressions of identity that mattered in their communities. Through the hybridization of several mediums of expression, this immigrant community was able to express its state allegiance, uphold group and local affiliations, and retain personal traditions as they negotiated their place in the empire. 


\section{References}

Adams, C.E.P., and Ray Laurence, eds. Travel and Geography in the Roman Empire. London: Routledge, 2001.

Alföldy, Géza. Noricum. Translated by Anthony Birley. London: Routledge, 1974.

Alföldy-Găzdac, A., S. Pánczél, L. Vass, C. Găzdac, I. Bajusz, N. Gudea. "Project 'Necropolis Porolissensis' Methods and Perspectives." Acta Terrae Septemcastrensis 6 no. 1 (2007): 9-17.

Ando, Clifford. Imperial Ideology and Provincial Loyalty in the Roman Empire. Berkeley: University of California Press, 2000.

Andreau, Jean. "Recherches récentes sur les mines romaines, II." Revue Numismatique 32 (1990): 85-108.

Apostol, Virgil. "Funerary Architecture in Alburnus Maior (Roşia Montană): The Circular Monument." Dacia N.S. 48-49 (2004-2005): 249-282.

Baron, S., C.G. Tămaş, B. Cauuet and M. Munoz. "Lead isotope analyses of gold-silver ores from Roşia Montană (Romania): A first step of metal provenance study of Roman mining activity in Alburnus Maior (Roman Dacia)." Journal of Archaeological Science 38 (2011): 1090-1100.

Bartel, Brad. "Acculturation and Ethnicity in Roman Moesia Superior." In Centre and Periphery Comparative Studies in Archaeology. Edited by Tim Champion. Hoboken: Routledge, 1995.

Batty, Roger. Rome and the Nomads: The Pontic-Danube Realm in Antiquity. Oxford: Oxford University Press, 2007.

Baumann, Victor Henrich, ed. La vie rurale dans les provinces romaines: vici et villae: actes du IIIe Colloque roumano-suisse, Tulcea, 8-15 octobre 1995 à l'Institut de recherches eco-muséales de Tulcea. La Politique Édilitaire Dans Les Provinces De L'Empire Romain: IIème-IVème Siècles Après J. -C. Tulcea, Roumanie: Institutul de cercetări eco muzeale, 1998.

Bennett, Julian. Trajan: Optimus Princeps: A Life and Times. Bloomington: Indiana University Press, 1997.

Berger, Adolf. “A Labor Contract of A.D. 164: CIL, III, P. 948, No. X.” Classical Philology 43 no. 4 (1948): 231-242. 
Boardman, John. The Greeks Overseas: Their Early Colonies and Trade. London: Thames and Hudson, 1980.

Ciongradi, C., A. Timofan and V. Bârcă. "Eine neue Erwähnung des kastellum Starva in einer Inschrift aus Alburnus Maior. Studium zu Epigraphisch bezeugten kastella und vici im Dakischen Goldbergwerksgebiet." Zeitschrift für Papyrologie und Epigraphik 165 (2008): 249-266.

Craddock, P.T. Early Metal Mining and Production. Washington, D.C.: Smithsonian Institution Press, 1995.

Cuvigny, Helene. "The Amount of Wages Paid to the Quarry-Workers at Mon Claudianus." The Journal of Roman Studies 86 (1996): 139-145.

Damian, Paul, ed. Alburnus Maior I. Bucharest: Muzeul Național de Istorie a României, 2003. and Mihaela Simion. "Funerary Practices in the Necropolises belonging to the ancient communities at Alburnus Maior." In Funerary Practices in Europe, before and after the Roman Conquest $\left(3^{\text {rd }}\right.$ century $B C-3^{\text {rd }}$ century $\left.A D\right)$. Edited by Valerius Sîrbu and Sabin Adrian Luca. Acta Terrae Septemcastrensis Journal Proceedings of the 8th International Colloquium of Funerary Archaeology 6 no. 1 (2007): 141-153.

Davies, Oliver. Roman Mines in Europe. New York: Arno Press, 1979.

Davies, Roy W., David John Breeze, and Valerie A. Maxfield. Service in the Roman Army. New York: Columbia University Press, 1989.

Davison, David, Vincent L. Gaffney, Emilio Marin, and J. J. Wilkes. Dalmatia: Research in the Roman Province 1970-2001: Papers in Honour of J.J. Wilkes. BAR International Series 1576. Oxford: Archaeopress, 2006.

Dise, Robert L. Cultural Change and Imperial Administration: The Middle Danube Provinces of the Roman Empire. New York: P. Lang, 1991.

Domergue, Claude. Les Mines Antiques: La production de métaux aux époques grecque et romaine. Paris: Picard, 2008.

ed. Minería y metalurgia en las antiguas civilizaciones mediterráneas y europeas: Coloquio Internacional Asociado, Madrid, 24-28 octobre 1985, organizado por el Departamento de Historia Antigua de la Universidad Complutense (Madrid) y L'URA 997 CNRS de l'Université de Toulouse-Le Mirail. 
Madrid: Ministerio de Cultura, Dirección General de Bellas Artes y Archivos, Instituto de Conservación y Restauración de Bienes Culturales, 1989.

Duncan, G. L. Coin Circulation in the Danubian and Balkan Provinces of the Roman Empire, AD 294-578. London: Royal Numismatic Society, 1993.

Duncan-Jones, Richard. The Economy of the Roman Empire: Quantitative Studies. Cambridge: Cambridge University Press, 1974.

Dušanić, Slobodan. “The Valle Ponti Lead Ingots: Notes on Roman Notables' Commercial Activities in Free Illyricum at the Beginning of the Principate." Starinar 58 (2008): 107-118.

"Prosopographic Notes on Roman Mining in Moesia Superior: The Families of Wealthy Immigrants in the Mining Districts of Moesia Superior - Summary." СТАРИНАР 56 (2006): 85-102.

"Army and Mining in Moesia Superior." In Kaiser, Heer und Gesellschaft in der Römischen Kaiserzeit. Edited by Géza Alföldy, Brian Dobson, and Werner Eck. Series Heidelberger Althistorische Beitrage un Epigraphische Studien 31. Stuttgartt: Franz Steiner Verlag, 2000.

_ “The Miner's Cults in Illyricum,” PALLAS 50 (1999): 129-139. "Late Roman Mining in Illyricum: Historical Observations." In Ancient mining and metallurgy in Southeast Europe: International Symposium Donji Milanovac, May 20-25, 1990, 247-270. Belgrade: Archaeological Institute, 1995.

Dzino, Danijel. Illyricum in Roman Politics, 229 BC-AD 68. Cambridge: Cambridge University Press, 2010.

Ellis, L. “"Terra Desert': Population, Politics and the [de]Colonization of Dacia." World Archaeology. Population and Demography Series 30, no. 2 (1998): 220-237.

Finley, M.I. The Ancient Economy. Berkeley: University of California Press, 1973.

Florescu, Radu. The Art of Dacian-Roman Antiquity. Bucharest: Meridiane Publishing House, 1986.

Fodorean, Florin. "Viae militaris in Dacia during Trajan - Abstract." DACIA AVGVSTI PROVINCIA: Crearea provinciei, actele simpozionului desfăşurat (October 2006): 1-2. 
Fulford, Michael. "Territorial Expansion and the Roman Empire." Archaeology of Empires 23 (1992): 294-305.

Garnsey, Peter and Richard P. Saller. The Early Principate: Augustus to Trajan. Oxford: Published for the Classical Association, at the Clarendon Press, 1982.

Glodariu, Ioan. Dacain Trade with the Hellenistic and Roman World. Translated by Nubar Hampartumian. BAR Supplementary Series 8. Oxford: BAR International Series, 1976.

Goldsworthy, Adrian Keith, Ian Haynes, and C. E. P. Adams. The Roman Army as a Community: Including Papers of a Conference held at Birkbeck College, University of London, on 11-12 January 1997. Portsmouth: Journal of Roman Archaeology, 1999.

Grattan, J., L. Abu Karaki, D. Hine, H. Toland, D. Gilbertson, Z. al-Saad, and B. Pyatt. "Analyses of Patterns of Copper and Lead Mineralization in Human Skeletons excavated from an Ancient Mining and Smelting Centre in the Jordanian Desert: A reconnaissance study.” Mineralogical Magazine 69 no. 5 (2005): 653-666.

- S. Huxley, Lotus Karaki, Harry Toland, D. Gilbertson, Brian Pyatt, and Ziad AlSaad, n.d. "'Death...more desirable than life'? The human skeletal record and toxicological implications of ancient copper mining and smelting in Wadi Faynan, southwestern Jordan." SAGE Publications 18 (2002): 297-307.

Healy, John F. Mining and Metallurgy in the Greek and Roman World. London: Thames and Hudson, 1978.

Hales, Shelley and Tamar Hodos, eds. Material Culture and Social Identities in the Ancient World. Cambridge: Cambridge University Press, 2010.

Hanson, W.S. "Civilians on Frontiers," In Limes XIX: Proceedings of the XIXth International Congress of Roman Frontier Studies held in Pécs, Hungary, September 2003. Edited by Zsolt Visy and Pécsi Tudományegyetem. International Congress of Roman Frontier Studies. Pécs: University of Pécs, 2005.

_ Lindsay Allason-Jones, and David John Breeze, eds. The Army and Frontiers of Rome: Papers Offered to David J. Breeze on the Occasion of his Sixty-Fifth Birthday and his Retirement from Historic Scotland. JRA Supplementary Series 74. Portsmouth: Journal of Roman Archaeology, 2009. and Ian Haynes, eds., Roman Dacia: The making of a Provincial Society. Roman Archaeology Conference 56. Portsmouth: Journal of Roman Archaeology, 2004. 
Hirt, Alfred Michael. Imperial Mines and Quarries in the Roman World: Organizational Aspects, 27 BC - AD 235. Oxford: Oxford University Press, 2010.

Iancu, Avram. Apulum X: Arheologie-Istorie-Etnografie in Memoriam Avram Iancu: 1872 - 1972. Alba Iulia: Muzeul de Istorie, 1972.

Ionescu, Corina, Lucreţia Ghergari and Ovidiu Ţentea. "Interdisciplinary (MineralogicalGeological-Archaeological) Study on the Tegular Material Belonging to the Legion XIII Gemina from Alburnus Maior (Roşia Montană) and Apulum (Alba Iulia): Possible Raw Materials Sources," Cercetări Arheologice 13 (2006): 413436.

Jones, Siân. The Archaeology of Ethnicity: Constructing Identities in the Past and Present. London: Routledge, 1997.

King, Charles. The Black Sea: A History. Oxford: Oxford University Press, 2004.

Lica, Vasile. The Coming of Rome in the Dacian World. Translated by Carmen Patac and Mariana Neagu. Konstanz: Universitätsverlag Konstanz, 2000.

MacMullen, Ramsay. Roman Social Relations, 50 B.C. to A.D. 284. New Haven: Yale University Press, 1974.

Mattingly, David J. Imperialism, Power and Identity: Experiencing the Roman Empire. Princeton: Princeton University Press, 2011.

Mihailescu-Birliba, V. "Some inferences from the numismatic evidence across a Roman frontier segment (north-west of Dacia Porolissensis)." OXBOW MONOGRAPH 91 (1997): 241-246.

Moatti, Claudia. "Translation, Migration and Communication in the Roman Empire: Three Aspects of Movement in History." Classical Antiquity 25 (2006): 109-140.

Mócsy, András. Pannonia and Upper Moesia: A History of the Middle Danube Provinces of the Roman Empire. Translated by Sheppard Frere. London: Routledge, 1974.

Nemeti, Sorin. "Bindus-Neptunus and Ianus Geminus at Alburnus Maior (Dacia)." Studia Historica. Historia Antigua, 22 (2004): 91-101.

Noeske, Hans-Christoph. "Studien zur Verwaltung und Bevölkerung der dakischen Goldbergwerke.” Bonner Jahrbücher 177 (1977): 271-416. 
Noy, D. "Epigraphic evidence for Immigrants at Rome and in Roman Britain." In Roman Diasporas: Archaeological Approaches to Mobility and Diversity in the Roman Empire. Edited by Hella Eckardt. Portsmouth: Journal of Roman Archaeology, 2010.

Oleson, John Peter. Greek and Roman Mechanical Water-Lifting Devices: The History of a Technology. Toronto: University of Toronto Press, 1984.

Oltean, Ioana Adina. Dacia: Landscape, Colonisation and Romanisation. London: Routledge, 2008.

— and W.S. Hanson. "Villa Settlements in Roman Transylvania." Journal of Roman Archaeology 20 (2007):113-137.

Onofrei, Cosmin. "Thracians in Roman Dacia. Military and Civilian Elements." Ephemeris Napocensis 28 (2008): 75-92.

Orejas, Almudena and F. Javier Sánchez-Palencia. "Mines, Territorial Organization, and Social Structure in Roman Iberia: Carthago Noua and the Peninsular Northwest." American Journal of Archaeology 106 no. 4 (2002): 581-599.

Pearce, John, Martin Millett, and Manuela Struck eds. Burial, Society and Context in the Roman World. Oxford: Oxbow Monograph, 2000.

Peretz, Daniel. "The Roman Interpreter and His Diplomatic and Military Roles." Historia: Zeitschift für Alte Geschichte 55 no. 4 (2006): 451-470.

Petolescu, C.C. "Les relations économiques de la Dacie Romaine." Memorias de Historia Antiqua 4 (1980): 51-59.

Petrović, Petar. Roman Limes on the Middle and Lower Danube. Belgrade: Archaeological Institute, 1996.

Phang, Sara Elise. Roman Military Service: Ideologies of Discipline in the late Republic and early Principate. Cambridge: Cambridge University Press, 2008.

Piso, Ioan. "Gli Illiri ad Alburnus Maior." In Dall'Adriatico al Danubio. L'illirico nell'età greca e romana. Edited by Gianpaolo Urso. Pisa: ETS, 2004.

Pitts, Martin. "The Emperor's New Clothes? The Utility of Identity in Roman Archaeology." American Journal of Archaeology 111 (2007): 693-713. 
Popa, Alexandru, Vasile Moga, and Radu Ciobanu. "Sapaturile de salvare de la Ampelum (Zlatna) / The Saving Excavations from Ampelum (Zlatna)," Apulum: Acta Musei Apulensis 23 (1986):105-118.

Rossi, Lino. Trajan's Column and the Dacian Wars. Ithaca, N.Y.: Cornell University Press, 1971.

Scheidel, Walter, Ian Morris, and Richard P. Saller. The Cambridge Economic History of the Greco-Roman World. Cambridge, UK: Cambridge University Press, 2007.

Scullard, H.H. Festivals and Ceremonies of the Roman Republic. Ithaca: Cornell University Press, 1981.

Shepherd, R. Ancient Mining. London: Published for the Institution of Mining and Metallurgy by Elsevier Applied Science, 1993.

Simion, Mihaela, Virgil Apostol, Decebal Vleja and Adela Bâltâc. Alburnus Maior II, Monumentul Funerar Circular $=$ The Circular Funeral Monument . Bucharest: DAIM, 2005.

Sipilä, Joonas. The Reorganization of Provincial Territories in Light of the Imperial Decision-Making Process: Later Roman Arabia and Tres Palaestinae as Case Studies. Helsinki: Societas Scientiarum Fennica, 2009.

Sotropa, Valeriu. Le droit Romain en Dacie. Amsterdam: JC Gieben, 1990.

Stefan, Alexandre Simon. Les guerres daciques de Domitien et de Trajan: Architecture militaire, topographie, images et histoire. Roma: Ecole française de Rome, 2005.

Tejral, J. "The Roman Military Impact and the Natives North of the Middle Danube During the 1st centuries AD." In Roman Frontier Studies 1995: Proceedings of the XVIth International Congress of Roman Frontier Studies. Edited by Willy Groenman-Van Waateringe. Oxford: Oxbow, 1997.

Temporini, Hidegard, Sechster Band, and Wolfgang Haase, eds. Aufstieg und Niedergang der Romischen Welt 2 no. 6. Berlin: Walter de Gruyter, 1977.

Țentea, Ovidiu. “Legion XIII Gemina and Alburnus Maior.” Apulum 40 (2003): 253-265.

Țeposu-Marinescu, Lucia. Funerary Monuments in Dacia Superior and Dacia Porolissensis. Oxford: B.A.R., 1982.

Thompson, F.H. The Archaeology of Greek and Roman Slavery. London: Duckworth, 2003. 
Varga, Rada. "The Peregrine Names from Dacia." Acta Musei Napocensis 43-44, no. 1 (2008): 233-246.

Wells, Peter S. Beyond Celts, Germans and Scythians. London: Duckworth, 2001.

Wheeler, Everett L. "Rome's Dacian Wars: Domitian, Trajan, and Strategy on the Danube, Part I." The Journal of Military History 74 (2010): 1185-1228.

Wilkes, John J. The Illyrians. Oxford: Oxford University Press, 1992. Dalmatia. Cambridge: Harvard University Press, 1969.

Wilson, Andrew. "Machines, Power and the Ancient Economy." The Journal of Roman Studies 92 (2002): 1-32.

Woolf, Greg. Becoming Roman. Cambridge: Cambridge University Press, 1998. 


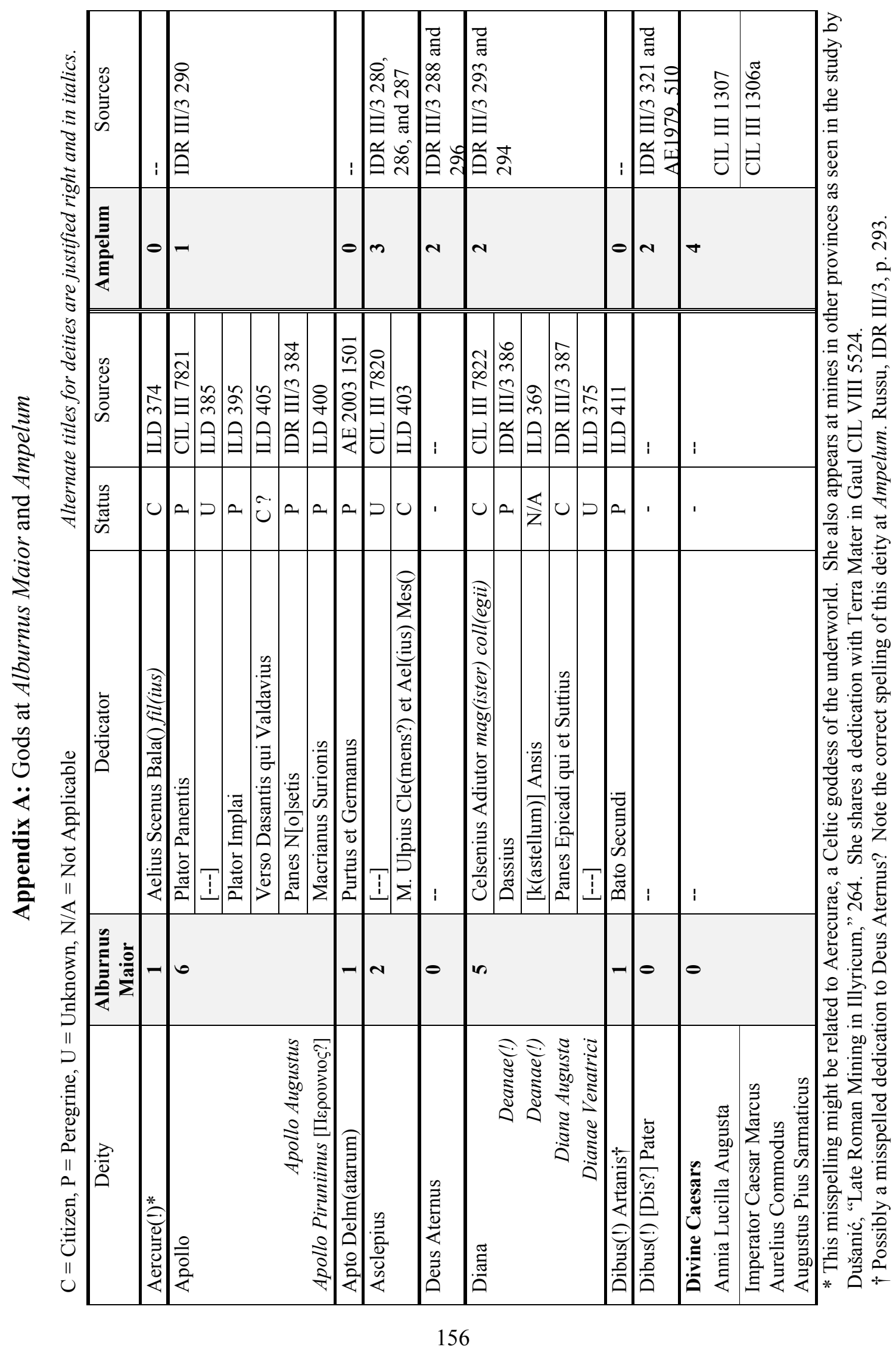




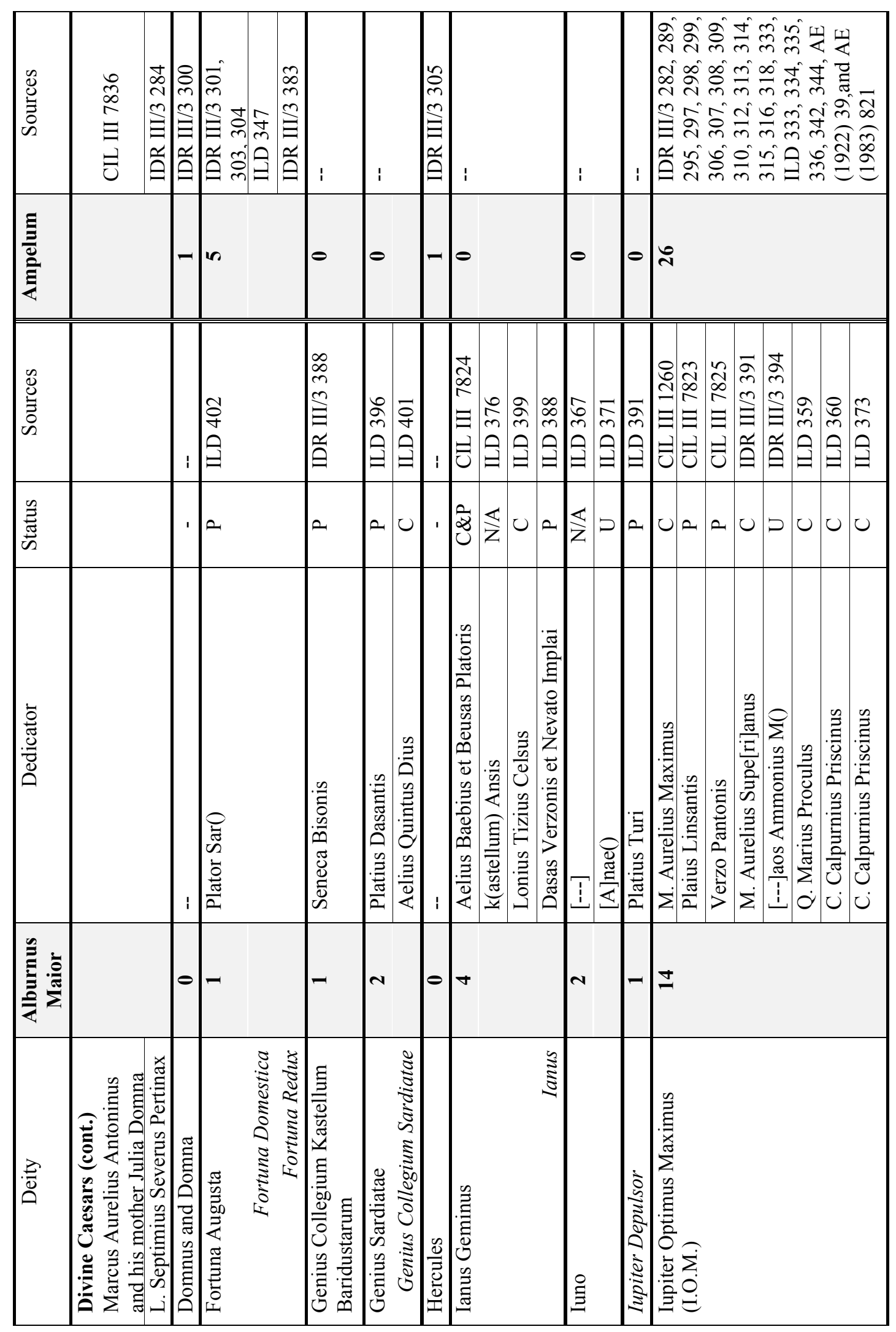




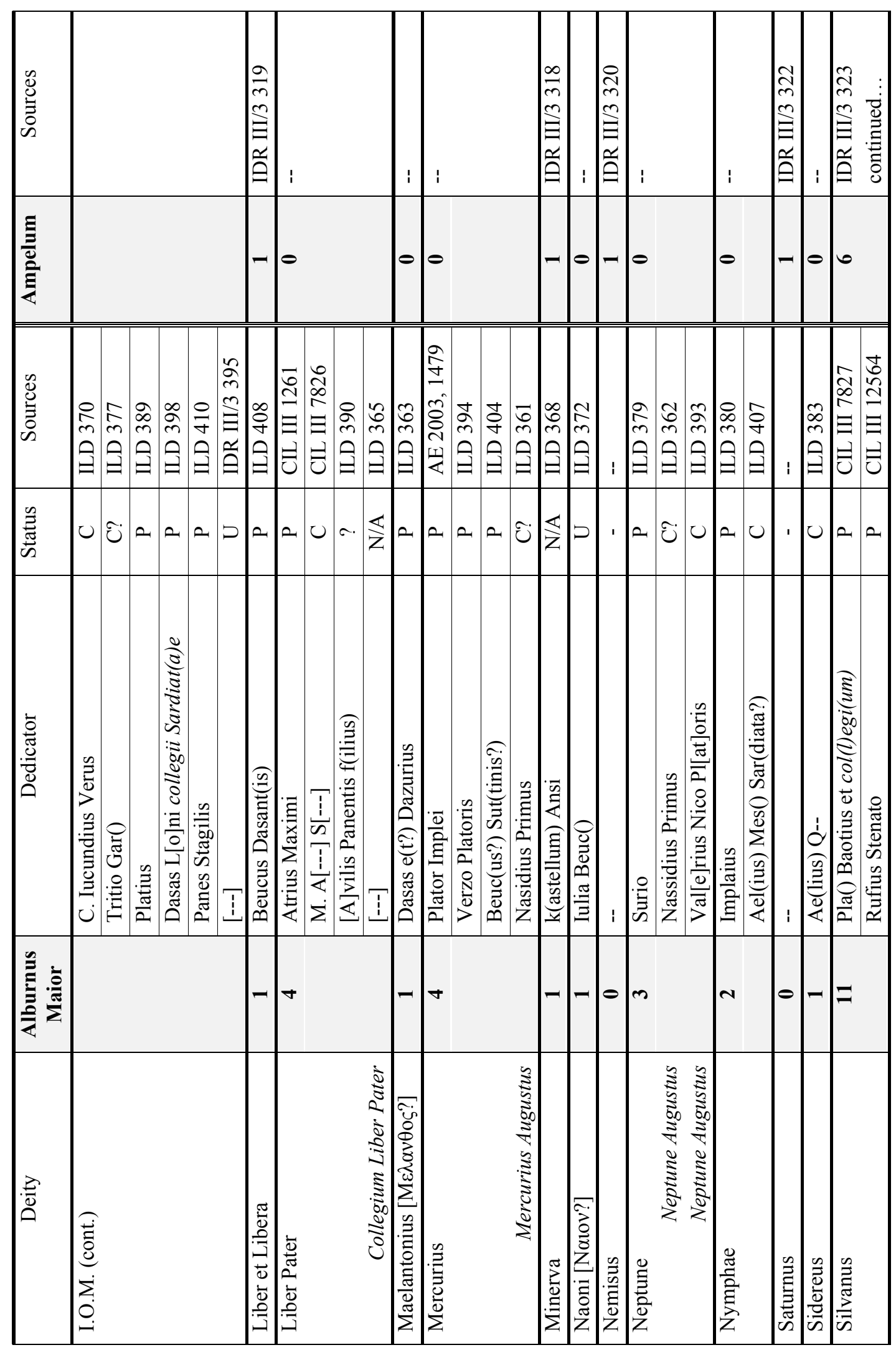




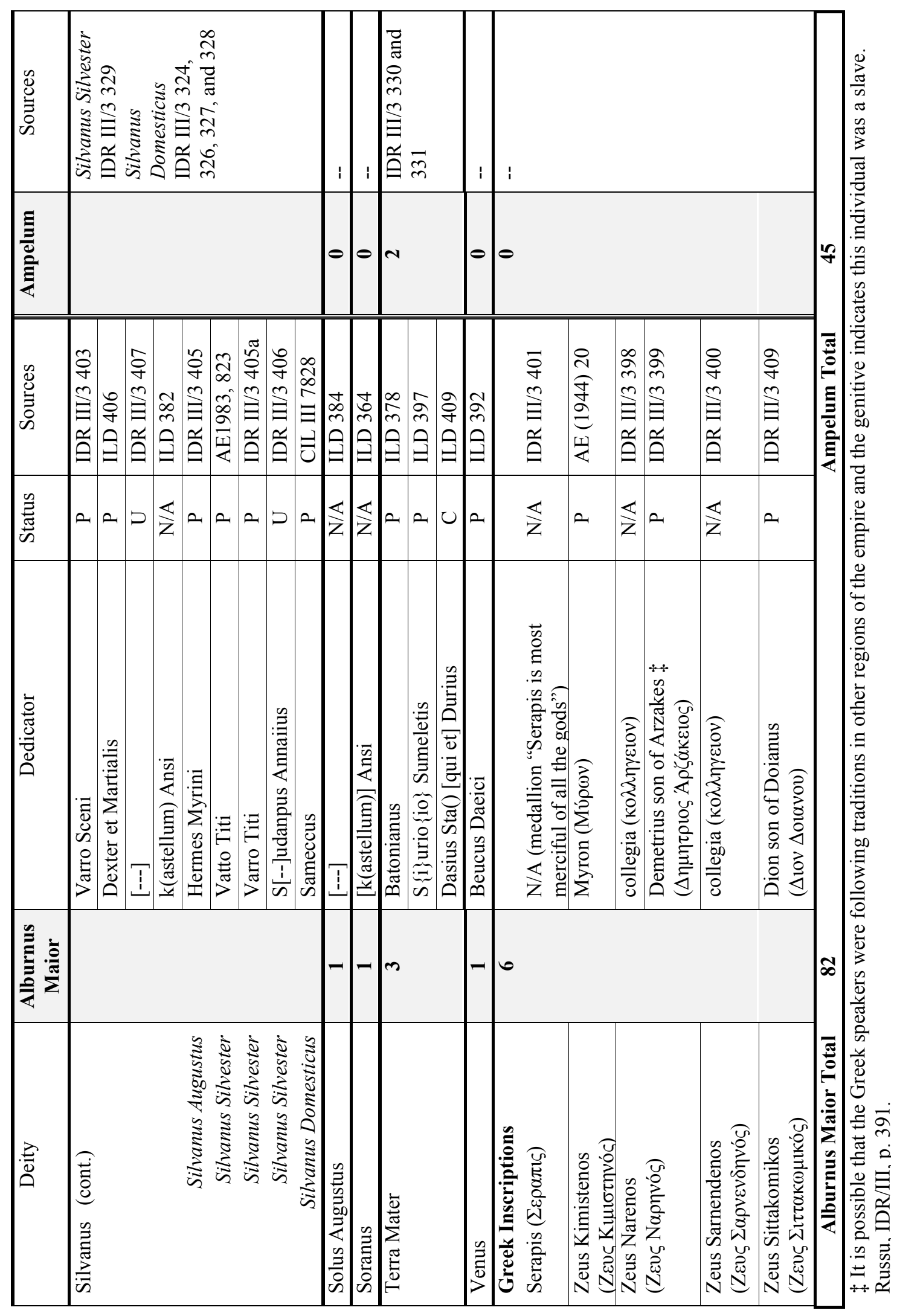




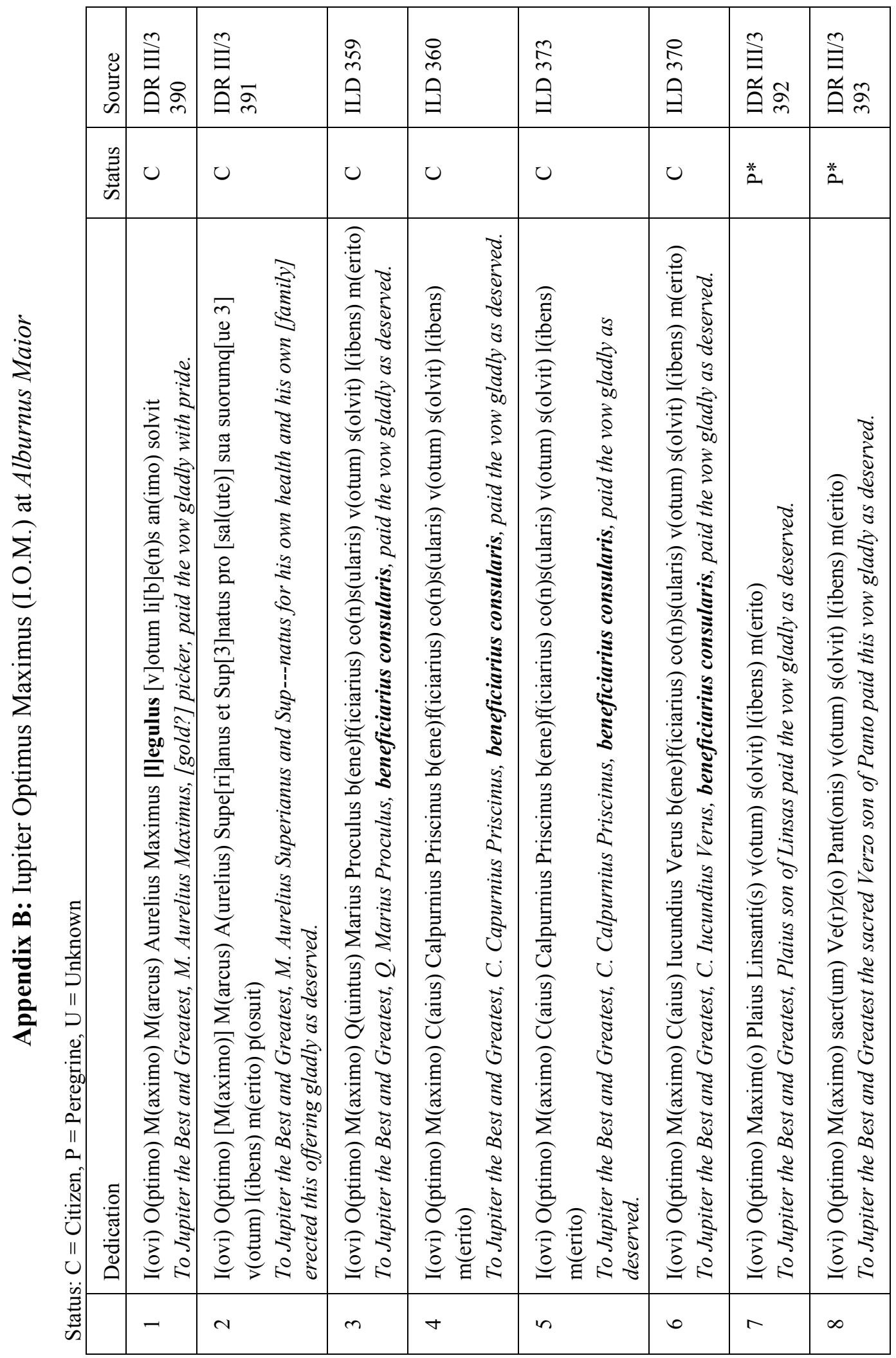




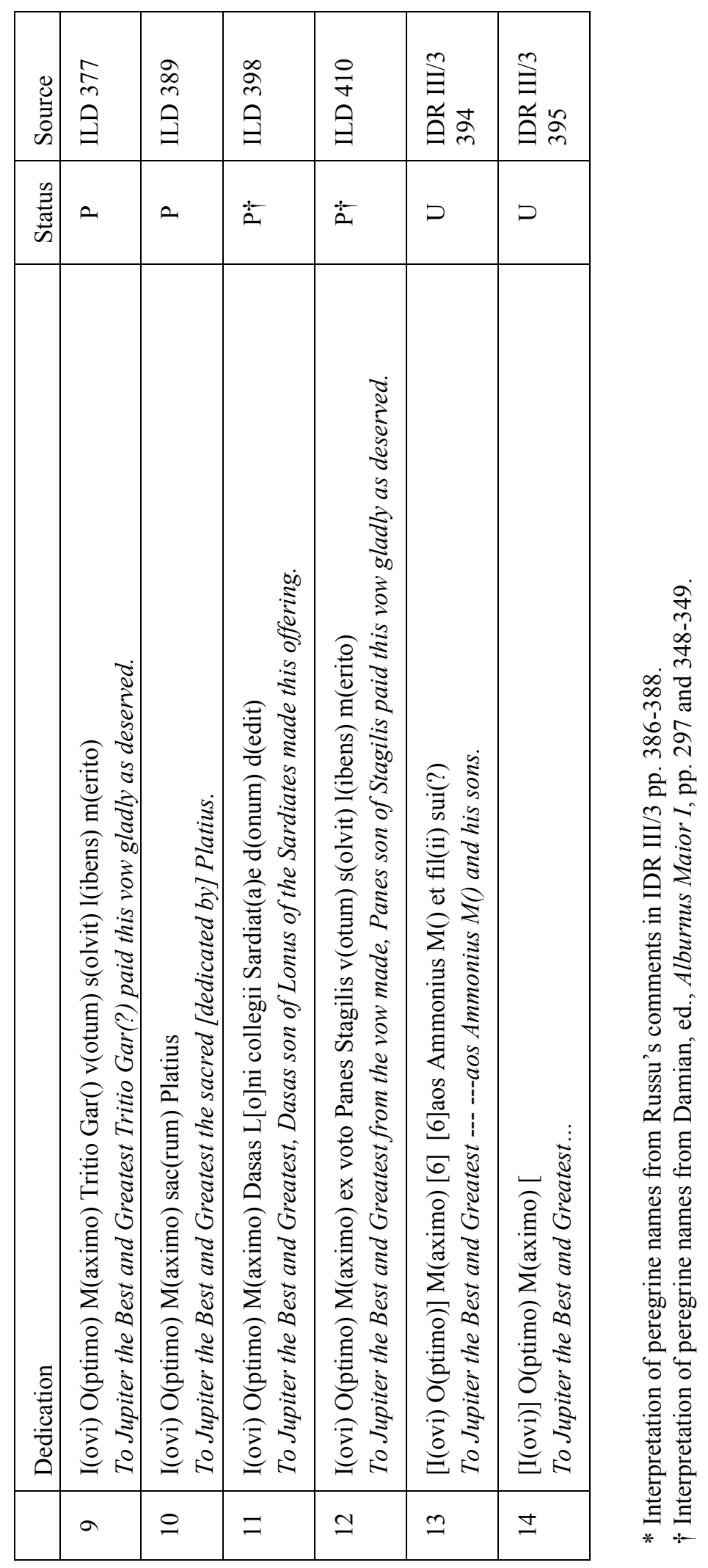




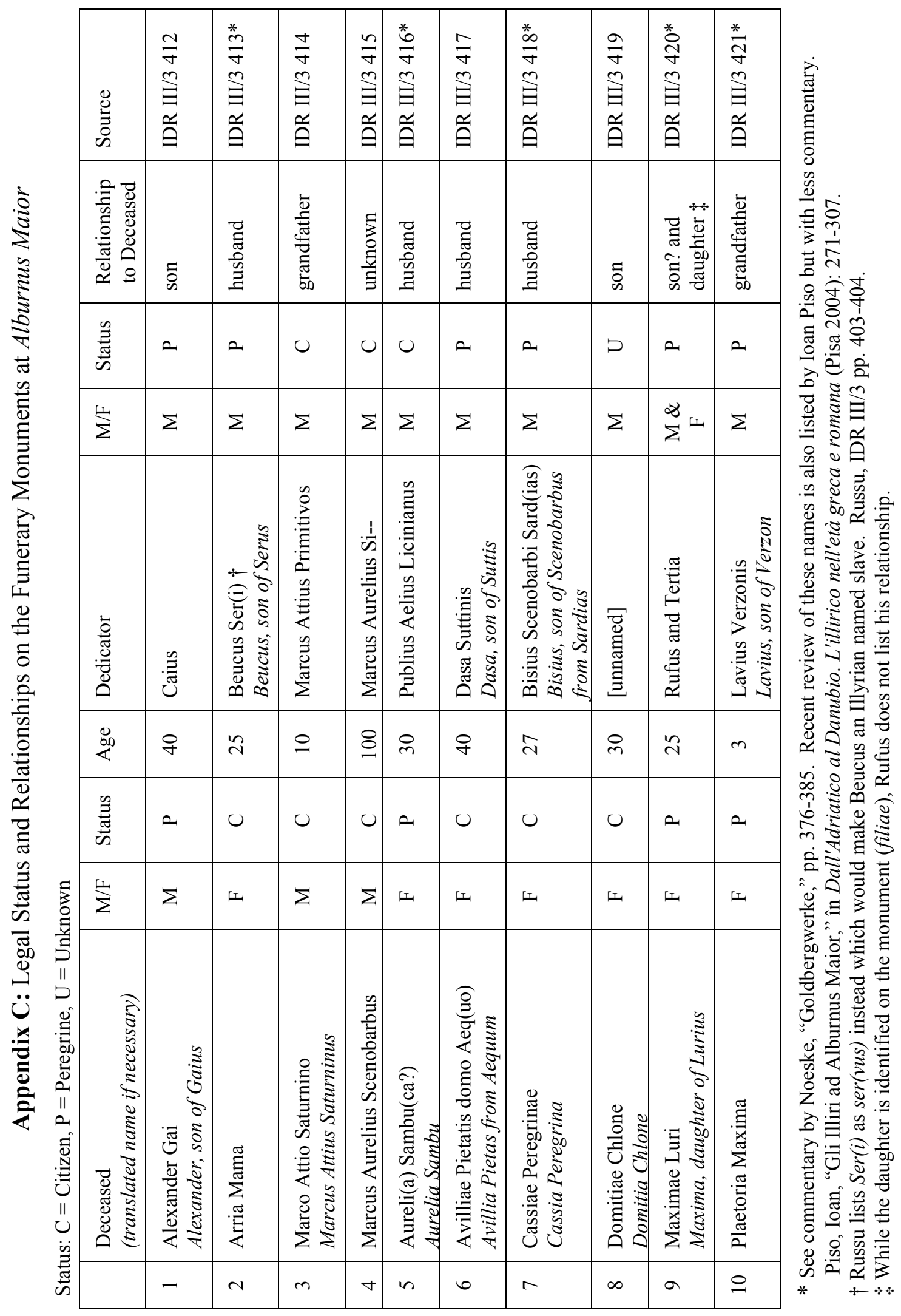




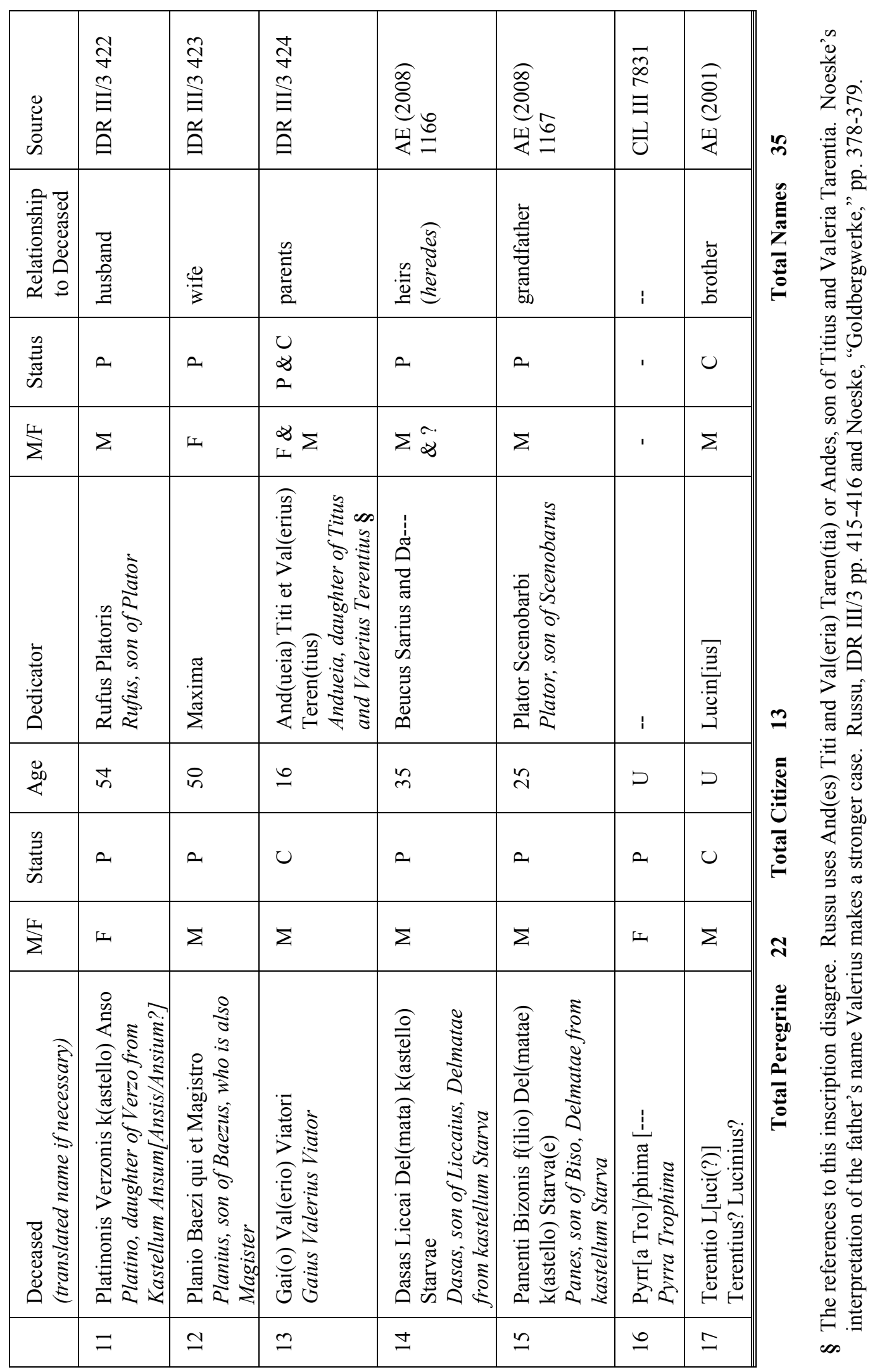




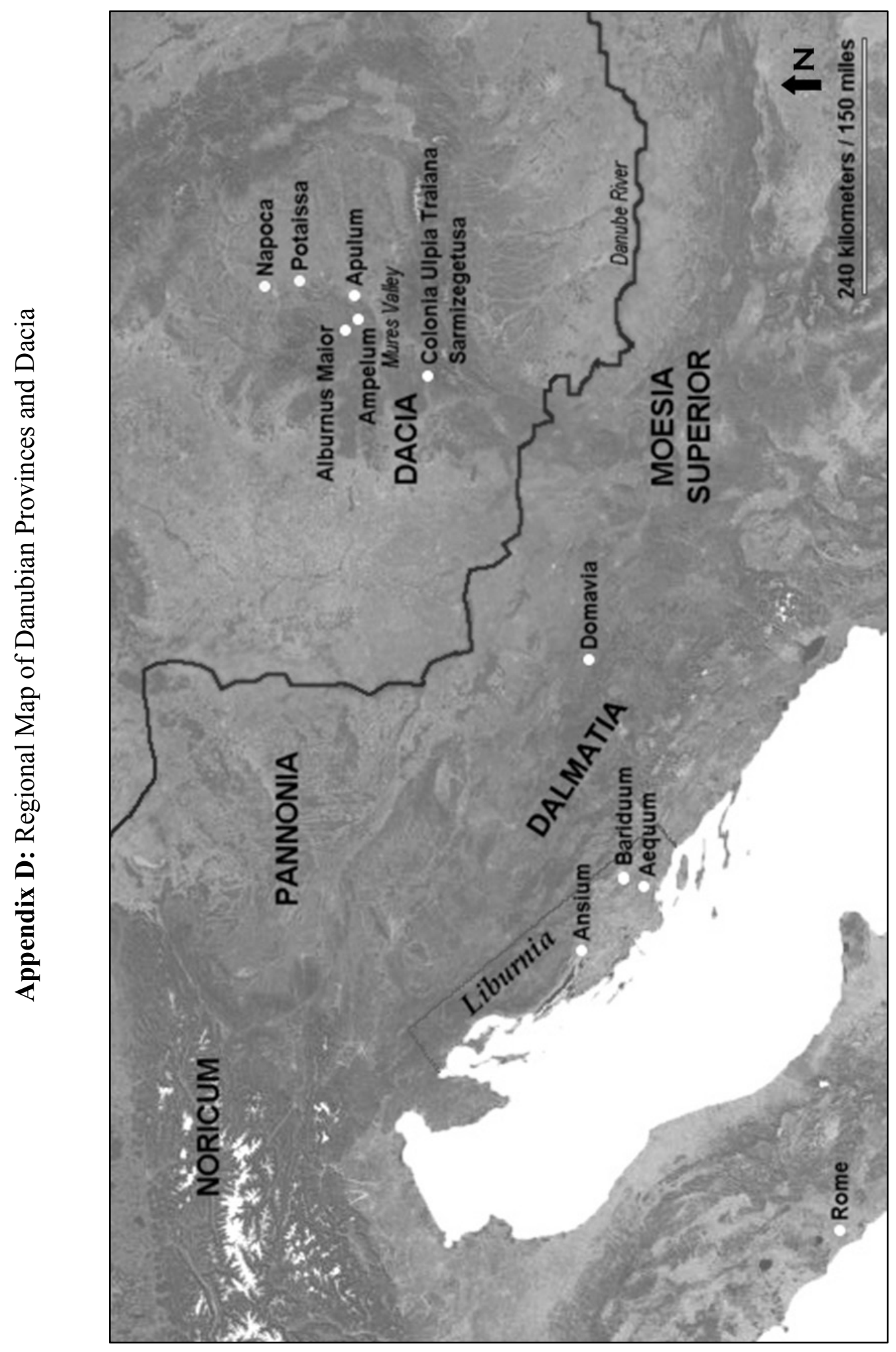




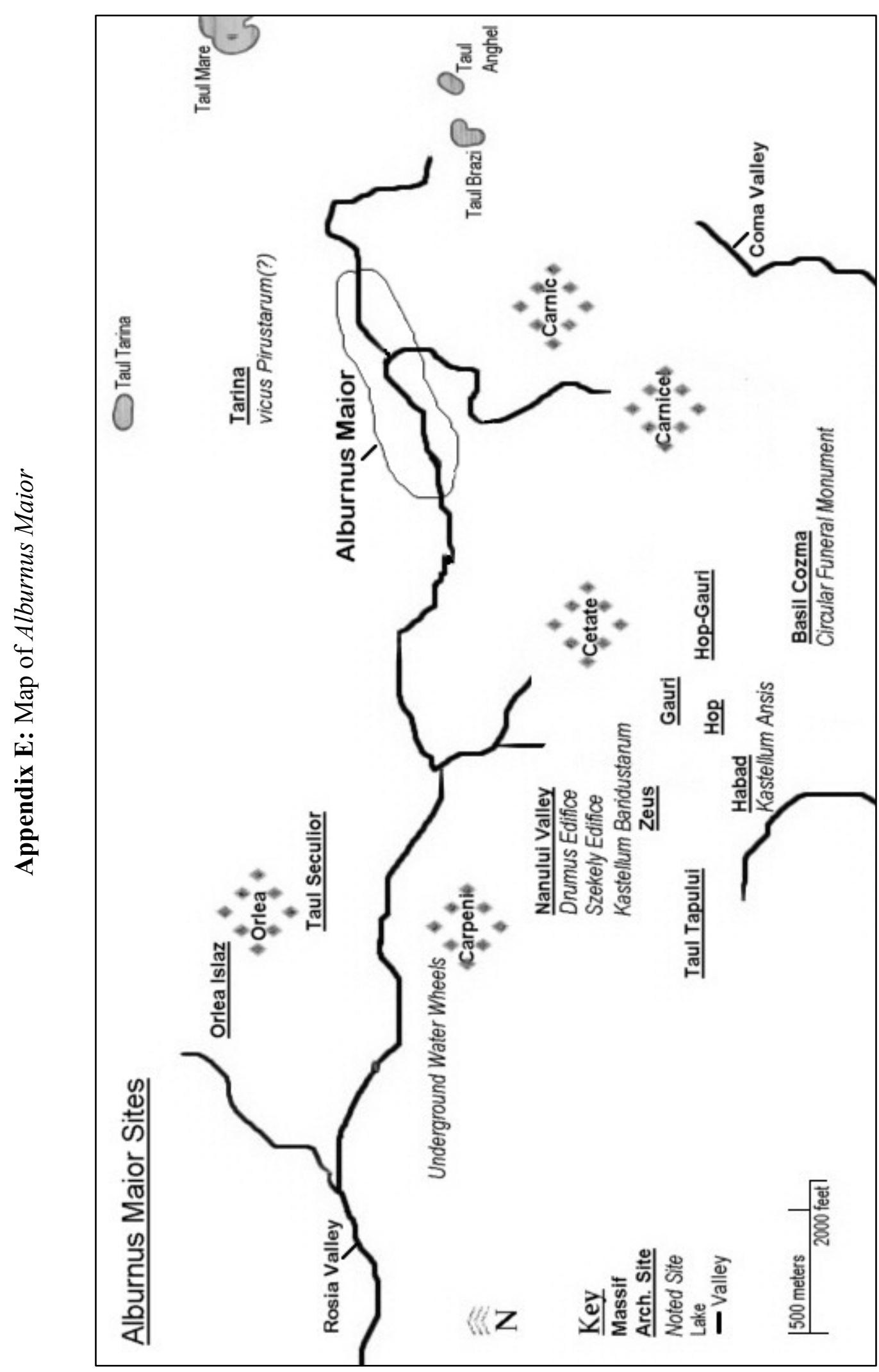




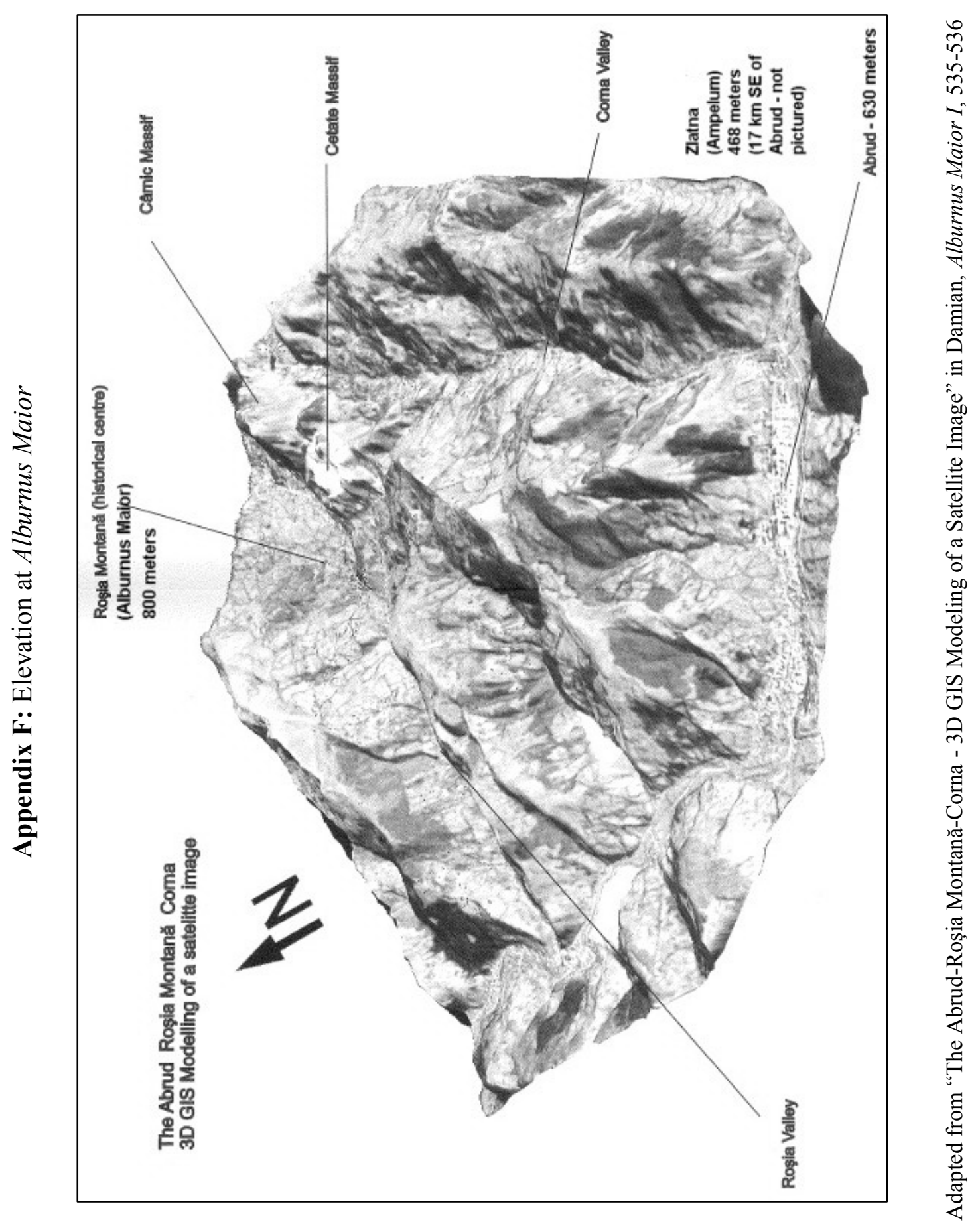




\section{Appendix G: Translation of Contract X (Memmius's Contract)}

[Macri] no et Celso co(n)s(ulibus) XIII Kal(endas) Iunias Flavius Secundinus scripsi rogatus a Memmio Asclepi quia se lit[ter] as scire negavit, it quod dixsit se locas[se] et locavit operas s[ua]s opere aurario Aurelio Adiutori ex ha[c] die [in] idus Novembres proxsimas [|(denarios) se]ptaginta liberisque $X^{483}$ (denarios) [mer]c[ede]m per [t] empora accipe[re] debebit qu[as] operas sanas v[ale]ntes [ed]e[re] debebit conductori [s(upra) s(cripto)] quod si invito condu[c] tore decedere aut c[e]ssare volue[rit dare] debebit in dies singulos [H]S V num(mos) (a)ere octus[s(is)] $c$ [ond] uct[or] i [si laborem] fluor inpedierit pro rata c[o] nputare de[bebit c] onduc[tor si t] empore peracto mercedem sol[v] endi moram fecerit ead[em] p[oena] tenebitur exceptis cessatis tribus.

\section{Actum Immenoso maiori. \\ Titus Beusantis qui et Bradua Socratio Socrationis $\quad$ [M]emmius Asclepi}

During the consulship of Macrinus and Celsus [164 CE] May 19th, I, Flavius Secuninus, wrote this, asked by Memmius, son of Asclepius because he did not know letters, who said he had contracted himself and contracted his labor in the gold mine to Aurelius Adiutor from this day until this next November 13th, for 70 denarii and 10 for his children. During this time he may receive pay. He will be responsible to give healthy and strong labor to the conductor named above. But if he decides to leave or to be inactive against the conductor's will he will be responsible to give for each day a fee of 5 sesterces 8 asses to the conductor. If a flood hinders work, he will be responsible to calculate pay as fixed. If by the end of the term of the lease the conductor delays making payment, he will be held to the same penalty with the excepted three day delay.

\section{Recorded at Immenosus Maior [settlement near Alburnus Maior]}

Titus, son of Beusan, who is also Bradua

Socratio, son of Socratio

Memmius, son of Asclepius

${ }^{483}$ This interpretation by Noeske is generally accepted in recent translations. Noeske, "Goldbergwerke," 398. For additional discussion, see Cuvigny, "Mon Claudianus," 142-143. 